\author{
MINISTÉRIO DA SAÚDE \\ FUNDAÇÃO OSWALDO CRUZ \\ INSTITUTO RENÉ RACHOU
}

PROGRAMA DE PÓS-GRADUAÇÃO EM SAÚDE COLETIVA

\begin{abstract}
A LUTA É COLETIVA, MAS A RESISTÊNCIA É INDIVIDUAL?
violências vivenciadas e estratégias de enfrentamento construídas pela comunidade universitária de lésbicas, gays, bissexuais, travestis, transexuais e outras identidades
\end{abstract}

por

Mateus Aparecido de Faria

Belo Horizonte

2018 

MATEUS APARECIDO DE FARIA

A LUTA É COLETIVA, MAS A RESISTÊNCIA É INDIVIDUAL?

violências vivenciadas e estratégias de enfrentamento

construídas pela comunidade universitária de lésbicas, gays,

bissexuais, travestis, transexuais e outras identidades

Dissertação apresentada ao

Programa de Pós-graduação em

Saúde Coletiva do Instituto René

Rachou da Fundação Oswaldo

Cruz, como requisito parcial para obtenção do título de Mestre em Saúde Coletiva - área de concentração Ciências Humanas e Sociais em Saúde.

Orientação: Celina Maria Modena

Coorientação: Maria Carmen Aires Gomes

Belo Horizonte 
Catalogação-na-fonte

Rede de Bibliotecas da FIOCRUZ

Biblioteca do IRR

CRB/6 1975

F224l Faria, Mateus Aparecido de.

2018

A luta é coletiva, mas a resistência é individual? Violências vivenciadas e estratégias de enfrentamento construídas pela comunidade universitária de lésbicas, gays, bissexuais, travestis, transexuais e outras identidades / Mateus A parecido de Faria - Belo Horizonte, 2018.

XX, 184 f.: il.; $210 \times 297 \mathrm{~mm}$.

Bibliografia: f. 111 - 125

Dissertação (mestrado) - Dissertação para obtenção do título de Mestre em Saúde Coletiva pelo Programa de PósGraduação em Saúde Coletiva do Instituto René Rachou. Área de concentração: Ciências Humanas e Sociais em Saúde.

1. Comportamento Sexual 2. Delitos Sexuais 3. Saúde Pública I. Título. II. Celina Maria Modena (Orientação). III. Maria Carmen Gomes Aires (Coorientação)

CDD-22. ed. -306.76 


\section{A LUTA É COLETIVA, MAS A RESISTÊNCIA É INDIVIDUAL?}

violências vivenciadas e estratégias de enfrentamento

construídas pela comunidade universitária de lésbicas, gays,

bissexuais, travestis, transexuais e outras identidades

Dissertação apresentada ao Programa de Pós-graduação em Saúde Coletiva do Instituto René Rachou da Fundação Oswaldo Cruz, como requisito parcial para obtenção do título de Mestre em Saúde Coletiva - área de concentração Ciências Humanas e Sociais em Saúde.

\section{Banca examinadora}

Profa. Dra. Celina Maria Modena (IRR-Fiocruz) - Presidenta

Profa. Dra. Érica Renata de Souza (UFMG) - Titular

Profa. Dra. Elza Machado de Melo (UFMG) - Titular

Profa. Dra. Andréa Moreira Lima (UNA - BH) - Suplente

Dissertação defendida e aprovada em Belo Horizonte, 03/07/2018. 
Dedico esse trabalho a todas, todes e todos que foram assassinadas por serem quem são.

(R)existiremos. 


\section{AGRADECIMENTOS}

As vidas trouxeram-me até aqui. Assim deveria agradecer a todas as pessoas que caminharam comigo, porém nessa dissertação vou me ater àquelas que contribuíram especificamente para a pesquisa. Às outras, agradeço em outros momentos. E continuo a caminhar com elas.

A Douglas de Paula, meu companheiro de vida, de luta, de pesquisa e de lar; A Celina Modena, orientadora de vida e parceira das loucuras acadêmicas;

A Maria Carmen Aires Gomes, por ter aceitado o desafio da co-orientação e ensinado-me a caminhar pelos discursos;

À Rede Afro LGBT, ao Una-se contra LGBTfobia e ao Instituto Pauline Reichstul por construírem essa pesquisa conosco;

A Juliana Aurora, que possibilitou o contato com as mulheres maravilhosas que enriqueceram esse trabalho e pelas reflexões que compartilhou comigo;

Às pessoas que integram o Comitê de Ética em Pesquisa do Instituto René Rachou, que ajudaram enormemente nos primeiros passos da pesquisa;

A Vera Neumann por ter me proporcionado experiências didático-pedagógicas que provocaram ricos processos reflexivos;

Ao Grupo de Pesquisa Políticas Públicas e Direitos Humanos em Saúde e Saneamento do IRR/Fiocruz, por fornecer apoio conceitual, metodológico e emocional durante a pesquisa;

Ao AFECTO (Abordagens faircloughianas para estudos sobre corpo/discurso textualmente orientado) da UFV, por proporcionar boas conversas sobre Análise do Discurso Crítica e softwares;

A Alberto Mesaque, Jhonatan Miranda e Thalita Rodrigues, pelas conversas filosóficas e científicas sobre violências;

A Miguel Bueno de Araújo Ariza, pelo apoio poliglota e emocional; 
A Alisson Bernardo, Ana Cristina Costa, Anelise de Souza, Dian Lucas e Gislaine Alves, por aceitarem e arrasarem nas pré-bancas;

A Coordenação de Pessoal de Nível Superior, pela concessão de bolsa de estudos. O presente trabalho foi realizado com apoio da Coordenação de Aperfeiçoamento de Pessoal de Nível Superior Brasil (CAPES) - Código de Financiamento 001. 


\section{RESUMO}

O objetivo desta pesquisa foi identificar e analisar as violências vivenciadas e as estratégias de enfrentamento desenvolvidas pela comunidade universitária de lésbicas, gays, bissexuais, travestis, transexuais e outras identidades $(\mathrm{LGBT}+)$. A justificativa da pesquisa embasa-se na necessidade de proporcionar subsídios para intervenções contra violências, constuir conhecimentos que não sejam cis-heteronormativos e compreender violências e estratégias de enfrentamentos pela perspectiva pós-estrutural. Esta pesquisa foi qualitativa, exploratória e descritivo-interpretativa, através de entrevistas com roteiro semiestruturado e contou com a participação de nove pessoas. A análise foi efetuada por meio da Análise do Discurso Crítica, com o auxílio do software KitConc 4.0. As pessoas participantes da pesquisa associaram à violência palavras que indicavam o processo violento, ao produto da violência ou ainda a sujeitos ou alvos das violências. Violência está ligada a medo, agressão, preconceito, abuso sexual e travesti. Identificou-se também atravessamentos de práticas discursivas religiosas, jurídicas, estruturalistas e biomédicas nas entrevistas. Tais construções sociodiscursivas trouxeram à tona um corpo-limite, que constrói sua existência pela ordem bélica, sendo impedido de ser sujeito de direitos. As cenas violentas mudam por vieses interseccionais como a relação interior-metrópole, a cor da pele e o gênero. Percebe-se a ideologia patriarcal como marcante nas entrevistas. As violências contra pessoas trans são mediadas preponderantemente pelo corpo, ao mesmo tempo alvo e instrumento. As relações de amizade são a principal forma de lidar com as violências contra pessoas LGBT, apesar de também ser violentadora. O oposto acontece com a família, que geralmente é apontada como a primeira cena violenta, no entanto é protetora algumas vezes. Outra estratégia de enfrentamento como buscar apoio a movimentos sociais e religião também faz parte dos atos performatizados de constituição frente à violência. $A$ não-estratégia configura-se como uma forma de lidar com a violência pela imobilidade. A partir das entrevistas foi identificada uma performance de vida como vigilante, a qual o constante estado de atenção é mantido, pois todo território se torna inimigo.

PALAVRAS-CHAVE: Minorias sexuais, Violência, LGBT+, Saúde Coletiva. 


\section{ABSTRACT}

The objective of this research was to identify and analyse the violence and coping strategies developed by the university lesbian, gay, bisexual and transgender community as well as other types of sexual and gender identities (LGBT+). The justification of this research is in the necessity to provide material for interventions against violence, build knowledge that is not cisheteronormative, and comprehend violence and coping strategies through a post-structuralist perspective. This paper was held qualitatively, exploratorily and descriptive-interpretive, by semi-structured interviews and the participation of nine people interviewed. The analysis was done according to Critical Discourse Analysis, with the help of KitConc 4.0 software. The participants of this research associated violence with words that indicated the process of violence, the product of violence or even subjects or targets to such violence. Violence is connected to fear, aggression, prejudice, sexual harassment and transvestite. It was also identified the crossing of religious, judicial, structuralists and biomedical discoursive practices in the interviews. The aforementioned social and discursive constructions brought up a body-limit, that builds its existence in a warlike fashion, blocked from being the subject of rights. Violent scenes change by intersectional biases such as the interior-metropolitan relationship, gender and skin colour. The patriarchal ideology is heavily noticed in the interviews. Violence against transgender people is mediated predominantly by the body, both target and instrument. Friendship relationships are the main form of dealing with violence against LGBT+ people, although it may also be violent. The opposite happens with family, which is usually pointed out as the perpetrator of the first violent experience. The family is, however, protective in a number of times. Another coping strategy, the search for support in social movements and religion, is also part of the performatized acts of coping when faced with violence. The non-strategy is configured as a way of dealing with violence by passivity. From the interviews, it was possible to identify a type of life performance based on vigilance, in which a permanent state of attention is sustained, for all territory becomes an enemy.

KEY-WORDS: Sexual minorities, Violence, LGBT+, Collective Health. 


\section{LISTA DE FIGURAS}

Figura 1 - Concepção tridimensional do discurso 46

Figura 2 - Processos, participantes e circunstâncias associadas. $\quad 48$

Figura 3 - Telas de trabalho do software KitConc, 2018. 


\section{LISTA DE TABELAS}

Tabela 1 - Perfil das pessoas entrevistadas segundo idade, gênero,

orientação sexual, raça/cor/etnia, escolaridade e local de residência

Tabela 2 - Grupos de significados das palavras relacionadas à violência,

53 quantidade de repetição e respectivos índices de chavicidade 


\section{LISTA DE ABREVIATURAS E SIGLAS}

\begin{tabular}{|c|c|}
\hline ACS & Agente Comunitário de Saúde \\
\hline UFMG & Universidade Federal de Minas Gerais \\
\hline UFRGS & Universidade Federal do Rio Grande do Sul \\
\hline VER-SUS & Vivências e Estágios na Realidade do Sistema Único de Saúde \\
\hline TCC & Trabalho de Conclusão de Curso \\
\hline IRR/Fiocruz & Instituto René Rachou/Fundação Oswaldo Cruz \\
\hline LGBT+ & $\begin{array}{l}\text { Lésbicas, Gays, Bissexuais, Travestis, Transexuais e Outras } \\
\text { Identidades }\end{array}$ \\
\hline OMS & Organização Mundial da Saúde \\
\hline $\mathrm{RMBH}$ & Região Metropolitana de Belo Horizonte \\
\hline CAAE & Certificado de Apresentação para Apreciação Ética \\
\hline ADC & Análise do Discurso Crítica \\
\hline SD & Teoria Social do Discurso \\
\hline
\end{tabular}




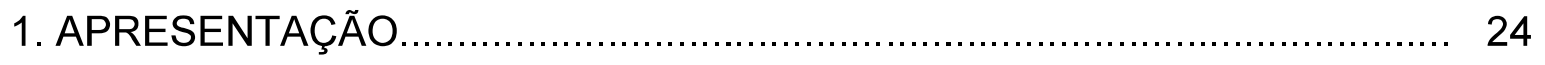

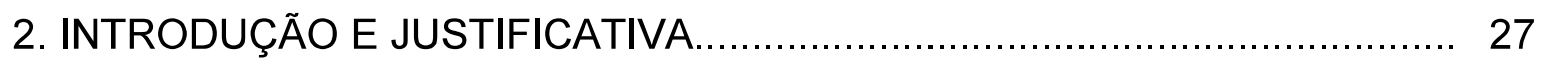

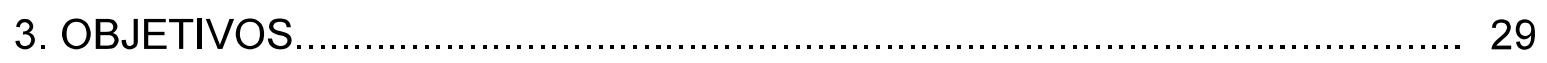

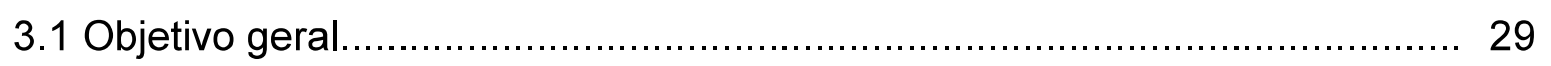

3.2 Objetivos específicos ....................................................................... 29

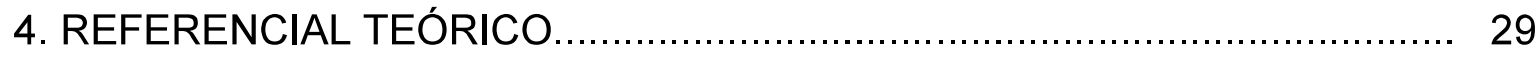

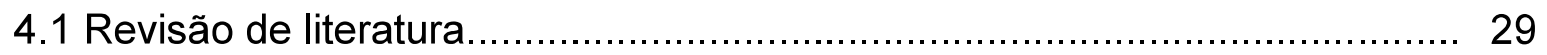

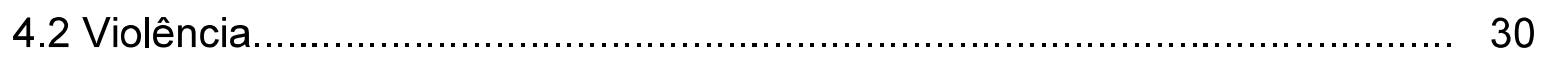

4.3 Performatividade de gênero................................................................ 36

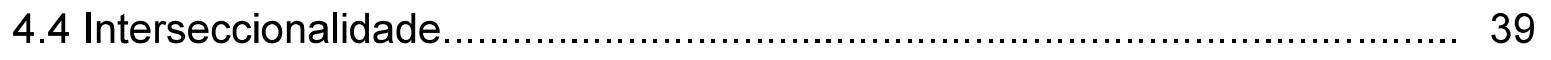

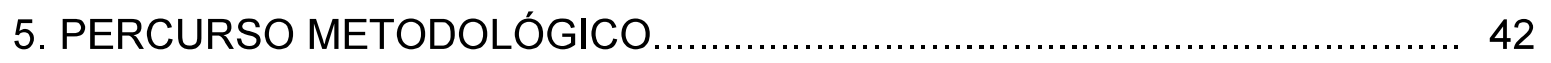

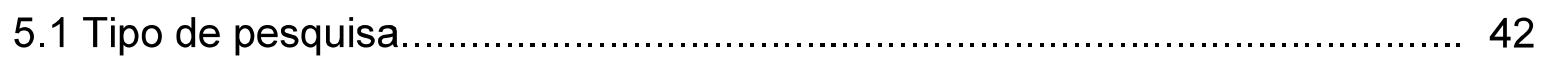

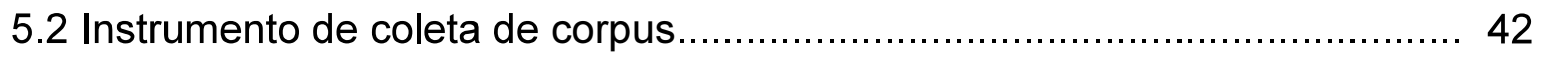

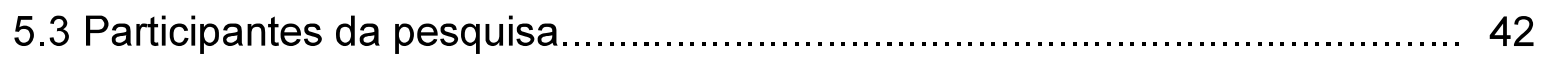

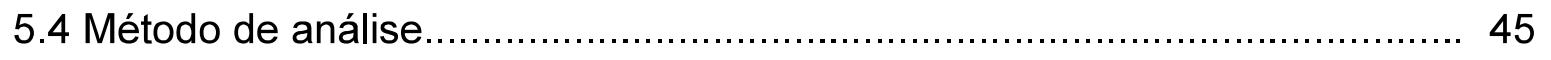

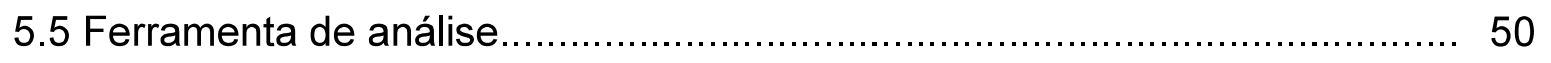

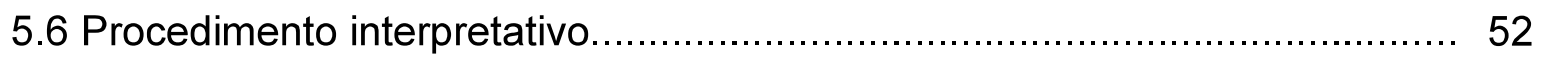

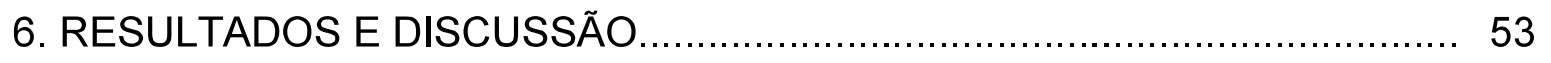

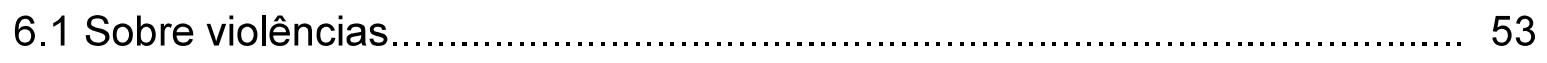

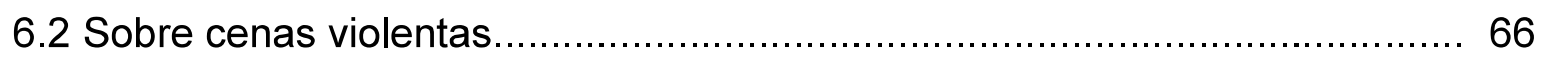

6.3 Sobre violências contra pessoas trans.................................................... 84

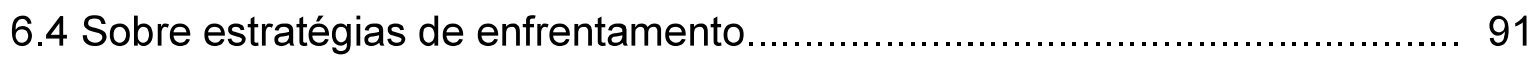

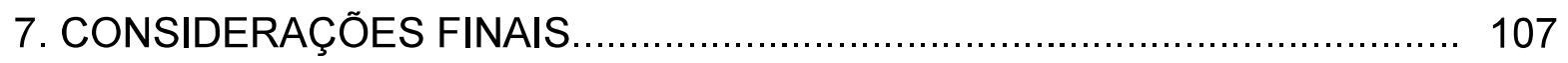

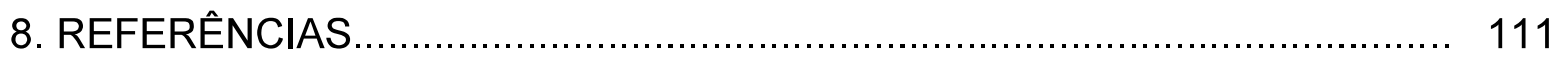


9. ANEXOS

9.1 Roteiro de entrevista semiestruturada.................................................. 126

9.2 Termo de Consentimento Livre e Esclarecido........................................... 128

9.3 Artigo de revisão sobre estratégias de enfrentamento ................................ 131

9.4 Artigo de revisão sobre violências contra pessoas LGBT+ ....................... 160 


\section{APRESENTAÇÃO}

De onde falo? Saúde Coletiva. Comecei errante nessa área como Agente Comunitário de Saúde (ACS) na cidade de Pará de Minas, interior de Minas Gerais, onde trabalhei na periferia. Lá cresci e fui criado por Lia, minha mãe, empregada doméstica e Faria, meu pai, operário. Por quase um ano atuei em projetos e atividades de promoção da saúde, prevenção de agravos, vigilância em saúde e planejamento do território. Parto para outros desafios em 2011 quando aprovado no vestibular para cursar a graduação em Gestão de Serviços de Saúde na Universidade Federal de Minas Gerais (UFMG).

Durante o período em que estive na UFMG, pude exercer meu direito à educação de modo mais abrangente: mobilidade nacional, participação em projetos de pesquisa, ensino e extensão, eventos, movimentos estudantis e sociais, além de oportunidades de facilitar processos de aprendizagens em espaços de educação popular e educação permanente em saúde. Isso só foi possível pelo suporte financeiro garantido por repasses financeiros federais às universidades públicas que, hoje, já não são prioridade - nem os repasses, nem as Universidades.

A Saúde Coletiva torna-se um campo nítido de trabalho para mim durante o período em que cursei um semestre no bacharelado em Saúde Coletiva na Universidade Federal do Rio Grande do Sul (UFRGS). Lá, onde estabeleci meu coração e meu lar, tive contatos e experiências de maior intensidade como o Vivências e Estágio da Realidade do Sistema Único de Saúde (VER-SUS) projeto de cooperação entre Ministério da Saúde e Organização Panamericana de Saúde para formação de estudantes de graduação para atuação no SUS local - a RadioWeb Saúde, projeto de extensão que objetivava a comunicação em saúde de forma mais ampla e acessível, o Elos Coletivo (movimento estudantil de alcance nacional que articulava vários projetos com secretarias de saúde visando a formação de profissionais voltada para o SUS) e o Movimento de Saúde dos Povos, grande rede internacional de ativistas que lutamos para garantir o direito à saúde e a saúde como direito, pensando globalmente, agindo localmente. 
Ao voltar para UFMG, venho com outros olhares, com outras ideias e busco colaborar fortemente na construção da identidade de Gestão de Serviços de Saúde: será que é um curso da Saúde Coletiva? Ou proveniente da Administração? Ou ainda um novo campo do conhecimento? Os inquietamentos chegam ao Trabalho de Conclusão de Curso (TCC), o qual busquei, mesmo a contragosto de outrem, esmiuçar as faces do curso (FARIA; SILVA, 2016a; 2016b).

Nesse entremeio do vestibular e o TCC, outras experiências auxiliaram-me na difícil tarefa de formar-se: o Fórum Metrô: Fórum de Educação de Jovens e Adultos da Região Metropolitana de Belo Horizonte/MG, coordenado pela professora Analise de Jesus da Silva, com quem pude contar nos momentos turbulentos; Projeto GestoresDeSaude.com, nascido do protagonismo estudantil e da necessidade de garantir o nosso direito à informação (PAULA et al., 2013; SILVA et al., 2013a; 2013b); e projetos de pesquisa na área de Saúde do Homem e Comunicação em Saúde, coordenados pela professora Celina Maria Modena, cientista brilhante e amorosa, que conduziu-me muito bem nos terrenos arenosos em que me adentrava.

Após o turbilhão TCC, aconteceu o estágio obrigatório, que escolhi fazer no centro de saúde Nossa Senhora de Fátima, na periferia da cidade de Belo Horizonte. Fui o único da minha turma a optar realizar o estágio na atenção básica e, com muito afinco e dedicação, aprendi com Toninho e Ana Cristina Magalhães, gerente e sub-gerente do Centro, a gestão do serviço. Pude então trabalhar em um lugar que, por vários momentos, foi minha ajuda por motivo de doença ou meu principal trabalho. Voltei para meu início, lá para as periferias, que precisam de nossos olhares, e gostaria de ter continuado após o semestre de atividades. No entanto, tive que buscar outros meios de existência - afinal preciso pagar minhas contas. Por causa da busca, sem sucesso, por emprego que decidi participar do processo seletivo para o Programa de Pós-graduação em Saúde Coletiva do IRR/Fiocruz. A aprovação em primeiro lugar reiterou a riqueza dos encontros nesta caminhada. 
"Nenhuma a menos! Ni una menos!". Foi em outubro de 2016 que a pesquisa geradora dessa dissertação começou a ser construída. Depois da frustração da primeira ideia de investigação e, a partir de uma prosa científica com Alberto Mesaque e Celina Modena, fui a uma manifestação no centro de Belo Horizonte contra o Feminicídio. O estopim foi a drogadição forçada, abuso sexual e empalamento de Lucia Pérez, mulher argentina de 16 anos. No meio do grande bloco formado majoritariamente por mulheres, com cartazes vermelhos e balões roxos, percebi que, já sabíamos, quais violências elas sofrem. Elas, mulheres com seus corpos de luta; que a cada oito minutos são vítimas fisicamente de outros corpos, semelhantes ou discordantes (FÓRUM DE SEGURANÇA PÚBLICA, 2017). Pensei: mas e aí? Como fazer para sobreviver então? Mas indaguei também: esta violência é sofrida apenas pelas mulheres, mas também pelos corpos dissidentes, discordantes, aqueles que fogem aos padrões normativos da matriz cis-heterossexual? Eis que me deparo fortemente com tais problematizações e inquietações. 


\section{INTRODUÇÃO E JUSTIFICATIVA}

A comunidade de lésbicas, gays, bissexuais, travestis, transexuais e outras identidades, que aqui tratarei genericamente de $\mathrm{LGBT}+{ }^{1}$, foi a escolhida como participante da pesquisa em função das violações de direitos ligados ao gênero e à orientação sexual em espaços educacionais, sanitários e políticos, e da constante estigmatização de pessoas LGBT+, com impactos expressivos no número de mortes ocasionadas por pessoas que estrutural, circunstancial ou simbolicamente matam outras pessoas com identidades não cisheterossexuais ${ }^{2}$. Gruenewald (2014) aponta o crescimento de homicídios antiLGBT+, apesar da taxa de homicídio da população em geral estar diminuindo. No Brasil, segundo relatório do Grupo Gay da Bahia (2018), foram 445 vítimas mortas pela discriminação contra LGBT+, perfazendo um assassinato a cada 19 horas em 2017. A maioria das mortes acontece com homens gays, seguido de travestis. Essa ponta do iceberg sangrento esconde as múltiplas violências cotidianas, que não aparecem com mesmo destaque nos jornais ou nas redes sociais, porém operam genocídio LGBT+ à medida que negam signos, que negam representatividade e nos obrigam a ficar em armários ou túmulos (FARIA; GOMES; MODENA, 2017). Destacam-se preconceitos nas entrelinhas ou explicitamente, os crimes de ódio, a falta de preparo de profissionais de saúde, o reforço da orientação sexual ou identidade de gênero como patologia, entre outras cenas de violência (RESENDE, 2016). Os dispositivos midiáticos e

\footnotetext{
A sigla LGBT+ carrega em si uma história de lutas, disputas discursivas e mudanças de paradigmas que não são o foco dessa pesquisa. Sugiro, para tanto, as produções científicas de Regina Facchini, em especial seu livro "Sopa de Letrinhas?: movimento homossexual e produção de identidades coletivas nos anos 90" e o relatório da I Conferência Nacional de Gays, Lésbicas, Bissexuais, Travestis e Transexuais que deliberou sobre a mudança da sigla (de GBBT para LGBT).

O termo cis é utilizado para se opor às identidades trans, ou seja, nomeia corpos que performatizam gênero e sexo linearmente. Uma pessoa trans precisa reinvidicar o reconhecimento enquanto homem ou mulher, pois não condiz com a designação social feita a ela, ao contrário de uma pessoa cis, em que seu gênero é aceito tacitamente. Já a heterossexualidade é um termo do campo das orientações sexuais: quer dizer que quando uma pessoa se identifica como heterossexual, ela diz que se relaciona afetivo-sexualmente com pessoas que não performatizam o mesmo gênero que o seu. Por exemplo quando um homem trans está casado com uma mulher cis, esta é uma relação heterossexual (ESUS, 2012).
} 
policiais aparecem como reprodutores de grande capacidade dessa ideologia que faz-se hegemônica: uso de termos chulos, colocando vítimas em posição de agentes da violência (MARTINS; FERNANDEZ; NASCIMENTO, 2010). Além disso, o sistema judiciário não reconhece as violências contra pessoas LGBT+ motivadas pela discriminação em torno do gênero ou da orientação sexual como crime tipificado, autorizando e mesmo legitimando perpetração desses atos.

No entanto as pessoas LGBT+ existem e resistem, por meio de ações e práticas que visam lidar com esse ambiente violento, as chamadas estratégias de enfrentamento.

Compreender de quais modos estamos enfrentando as violências e quais violências são essas é essencial para o fortalecimento de lutas e dos movimentos sociais, além disso propicia o fortalecimento da resistência, principalmente em lugares que são pretensamente individualizados/privados, como dentro de casa. A construção de conhecimentos por perspectivas menos heteronormativas sobre as vivências LGBT+, como a que buscamos aqui, também justifica a necessidade e importância dessa pesquisa. Ademais propõe-se inovar a literatura científica ao abordar violências e estratégias de enfrentamento de modo conjunto e pós-estrutural.

A dissertação está estruturada em capítulos, seguindo as orientações do Programa de Pós-graduação em Saúde Coletiva do IRR/Fiocruz: após a introdução, apresentaremos os objetivos da pesquisa, depois passamos para a revisão de literatura e referencial teórico e, posteriormente descrevemos nosso percurso metodológico, para enfim apresentarmos os resultados, com a discussão das análises. Dentre os elementos pós-textuais estão presentes as referências utilizadas, o roteiro construído para as entrevistas, o Termo de Consentimento Livre e Esclarecido e os artigos referentes à revisão de literatura. 


\section{OBJETIVOS}

\subsection{Objetivo geral}

ED Identificar e analisar as violências experienciadas e as estratégias de enfrentamento desenvolvidas pela comunidade universitária de lésbicas, gays, bissexuais, travestis e transexuais.

\subsection{Objetivos específicos}

E. Descrever e analisar as violências de gênero e de orientação sexual vivenciados por integrantes da comunidade LGBT+ universitária;

단 Descrever e analisar as estratégias de enfrentamento desenvolvidas contra violências por integrantes da comunidade LGBT+ universitária.

\section{REFERENCIAL TEÓRICO}

Para compreender o estado de arte da produção científica acerca das violências e estratégias de enfrentamento relacionadas à comunidade LGBT+, foi realizada revisão de literatura e organizada em formato de dois artigos. Depois tecemos considerações sobre as perspectivas conceituais de violência, teoria queer e interseccionalidade, que foram adotadas nessa pesquisa.

\subsection{Revisão de literatura}

Para possibilitar maior aprofundamento analítico da revisão de literatura, optouse pela elaboração de dois artigos, um sobre violências contra pessoas LGBTIQ+ intitulado Violências de gênero e/ou orientação sexual contra lésbicas, gays, bissexuais, trangêneros, intersexuais, queer e outras identidades: explicitando o ethos violento, a ser submetido ao Journal of Interpersonal Violence; e o segundo acerca das estratégias de enfrentamento desenvolvidas por essa comunidade cujo título é Coping strategies as performativity of lesbian, gay, bisexual, transgender, intersex, and other identities in the face of violence based on gender and/or sexual orientation, 
enviado ao Journal of Homosexuality. Eles estão presentes na seção Apêndices, itens 9.3 e 9.4, respectivamente.

\subsection{Violência}

As violências, contundentemente pluralizadas, são conceitos históricos que, até os pretensamente atemporais, carregam em si marcas epistemológicas de seus respectivos momentos de produção. Para embasar essa pesquisa, utilizaremos as abordagens e pesquisas que versam sobre conceitos de violência desenvolvidos por Judith Butler (2003; 2011; 2015a; 2015b) e Maria Cecília Minayo (2006), além das proposições da Organização Mundial de Saúde (2002) e do aparato jurídico brasileiro. Também lançaremos mão das contribuições de Hannah Arendt (2004) e Pierre Bourdieu (1989), quando for necessário.

Judith Butler é filósofa estadunidense e contribui grandemente para o pensamento pós-estruturalista, em especial sobre ética, gênero e política. Sua produção é extensa e profunda, de modo que nesta pesquisa vamos delinear um conceito de violência útil às análises e utilizar suas considerações sobre performatividade de gênero.

A violência, para Butler, não está determinada em uma obra, mas atravessada em seus livros e textos, de modo que aqui vamos delimitá-la para compreender melhor a problematização empreendida pela pesquisadora. Partimos principalmente da obra "Relatar a si mesmo: crítica da violência ética" (BUTLER, 2015a) para ler o mundo a partir do ethos coletivo, anacrônico, não compartilhado e sim imposto, fundado no pressuposto da unidade. A violência é, portanto, a forma com que esse ethos se mantém, impondo-se no presente (ainda que anacrônico), buscando suprimir contradições e conflitos que, de fato, existem nele (BUTLER, 2015a; SCHRAMM, 2009). Essa uniformização que ele busca provocar - já que não responde mais às variações culturais e sociais - é, de certa forma, exigir a sustentação de uma identidade que seja imutável e infinita, assim como aplicar a regra do outro a si próprio. 
Apesar dessa universalização da regra não ser necessariamente violenta, ela pode servir a tal propósito, a partir do viés do apagamento da subjetividade, em que se desconsidera a precariedade do sujeito em ser coerente (MIRANDA; RODRIGUES; BELO, 2017; BUTLER, 2015a). Tal violência, produzida pelo ethos totalitarista - no sentido de querer totalidade dos sujeitos como também ser a totalidade do coletivo - é materializada nos corpos que danifica.

Esses corpos, alvos ethoicos, experienciam atos violentos, que são entendidos ou reconhecidos como tal, portanto, não naturais. A reconhecibilidade de determinada experiência como violenta depende de quem recebe o dano ou ameaça. Poderia-se afirmar, então, que a ação violenta é performativa, uma vez que produz, no discurso, seu referente - a violência - através da (cit)ação repetida de outras experiências igualmente reconhecidas como violentas. Para haver esse processo de reconhecimento de atos e sujeitos, é necessário anteriormente conhecê-los pois, certamente, a maneira com que a experiência emerge dentro de um ethos prepara a possibilidade ou não de seus reconhecimentos (CANSECO, 2015).

Há de se considerar também que esses mesmos corpos, desde seu nascimento, são alvo de imposições de performatividades contra a sua vontade, ou seja, são, de alguma maneira, formados pela violência, configurando-os e constituindo-os. Justamente por essa condição, se tem a responsabilidade de não repetir essas mesmas violências e de romper com tal ciclo, em um movimento permanente de luta (BUTLER, 2015b).

Outra autora que se debruça nos estudos sobre violência é a socióloga brasileira Maria Cecília Minayo, que traz como proposta de pesquisas os efeitos da violência no campo da saúde. Ela descreve a violência como um campo disciplinar originário das ciências sociais, mas, em função de seus impactos nos sistemas de saúde e no perfil epidemiológico da população, a violência entra na pauta da saúde em meados dos anos 1980 (MINAYO, 2006).

Segundo a socióloga, as violências são múltiplas, por isso é inadequado usar a forma singularizada. Sua origem etimológica remete-se à força e ao constrangimento por meio do ímpeto físico de um indivíduo sobre o outro. Além 
disso, definir violência é difícil devido, principalmente, ao fato de que é um fenômeno subjetivo, manifestado no cotidiano, que carrega em si grande carga emocional para todas as pessoas envolvidas (MINAYO, 2006).

Em seu livro "Violência e Saúde", essa autora contrapõe duas perspectivas ocidentais sobre tal conceito - a popular e a erudita. No primeiro campo, a violência estaria associada à representação no inconsciente popular de que

a violência é parte intrínseca da vida social e resultante das relações, da comunicação e dos conflitos de poder. Nunca existiu uma sociedade sem violência, mas sempre existiram sociedades mais violentas que outras, cada uma com sua história (MINAYO, 2006, p.15).

Já a visão classificada como erudita percebe que a violência não é tão consensual quanto parece ser a popular. Apesar de todas considerarem-na, de certo modo, como força que vai de encontro à vontade do outro (seja ele quem ou o que for), as três correntes eruditas de pensamento descritas por Minayo divergem sobre sua origem, essência - ou se realmente há alguma - e sua funcionalidade em sociedade (MINAYO, 2006).

A primeira considera violência como a reação da população mais vulnerabilizada frente às crises sociais e à ausência de respostas às desigualdades pela sociedade ou pelo Estado. Tocqueville é um dos símbolos dessa corrente. A segunda é caracterizada pelas ideias de Hannah Arendt e Friedrich Engels que sustentam a tese de que a violência é um instrumento racional para fins específicos, em que as pessoas não seriam vítimas reativas delas e sim atores conscientes que a utilizam para se manterem no palco do poder. Por fim a terceira corrente possui forte influência cultural para afirmarem que a violência é uma pulsão, uma característica não desejada pela sociedade, já que esta prefere "a civilização, o diálogo e a convivência pacífica ao uso puro e simples da força física para se imporem" (MINAYO, 2006, p. 19).

Ao redesenhar a violência no mapa do conhecimento ocidental, Minayo busca construir sua perspectiva pela via pós-moderna, que considera a subjetividade nas ações violentas, indo além de processos culturais, cálculos racionais ou instâncias da macroestrutura. Ela aciona outro autor, Michel Wiervioka, para 
embasar sua tese de que há perda ou excesso de sentido na violência e que isso provoca a distorção da subjetividade gerando a possibilidade de atos violentos. Adicionalmente, posiciona a Igreja/religião como uma das instituições que corrobora as violências e, por fim, estabelece que se há violência, ela serve a algo - negócios ilegais, globalização, revoluções tecnoinformacionais, ou seja, está à disposição da ordem econômica para mantê-la e reforçá-la.

Pela via mais institucionalizada, há a Organização Mundial de Saúde (OMS) que desde a década de 1990 vem discutindo como a saúde pública global pode intervir nas situações de violência a fim de minimizar seu impacto no perfil epidemiológico da população mundial. Em seu relatório de 2002, a OMS reconhece que a violência sempre esteve presente na história da humanidade, porém "o mundo não tem de aceitá-la como parte inevitável da condição humana" (idem, p. 3).

Por sua definição, violência é

uso intencional da força física ou do poder, real ou em ameaça, contra si próprio, contra outra pessoa, ou contra um grupo ou uma comunidade, que resulte ou tenha grande possibilidade de resultar em lesão, morte, dano psicológico, deficiência de desenvolvimento ou privação (OMS, 2002, p. 5).

Segundo essa linha de pensamento proposta pela OMS, a intencionalidade é um pressuposto do ato violento, independente dos efeitos produzidos pela violência, em que cultura ela é praticada e seus respectivos significados, o entendimento das consequências do ato pelo agressor ou se possui natureza proativa ou reativa. Ademais, ao utilizar o termo poder em sua definição, a OMS busca ampliar a perspectiva convencional de violência, indo além da física e abarcando ameaças, intimidações, opressões, assédios, negligências e omissões.

Para construir melhor suas propostas de conceituação, a OMS propõe tipologias de violência: autoinfligida, subdividida em comportamento suicida e autoabuso (como a automutilação); interpessoal, compreendida como as violências cometidas pela família, incluindo parceiros(as) íntimos(as) e as ocorridas entre pessoas sem laços de parentesco ou afetivos, ocorridas 
geralmente fora do domicílio; e coletiva, praticada pelo Estado, por grupos sociais ou multidões - aqui entram as guerras, bloqueios econômicos, linchamentos, ataques terroristas, entre outros (OMS, 2002).

A OMS também cita a existência de violência física, sexual, psicológica e envolvendo privação de liberdade ou negligência, no entanto sem adentrar em suas peculiaridades. Tal definição de violência pela natureza do ato pode ser encontrada com maior detalhamento no ordenamento jurídico brasileiro descrito a seguir.

Foi a partir da lei n. 11.340 de 7 de agosto de 2006 que o aparato legal brasileiro passou a ser integrado por uma lei explícita que protegesse uma parcela populacional vulnerabilizada pelas relações de poder presentes na sociedade - as mulheres. Conhecida como Lei Maria da Penha ${ }^{3}$, esse dispositivo traz violência doméstica ou familiar como aquela que acontece por meio da ação ou omissão, originada pela percepção de gênero, que cause morte, sofrimento físico, sexual ou psicológico, lesão, dano moral ou patrimonial no âmbito domiciliar, familiar ou íntimo. Logo adiante a lei descreve os tipos de violência que podem ser vivenciados pelas mulheres: I) violência física é qualquer conduta que possa ofender a integridade ou saúde corporal; II) violência psicológica é entendida como ações que causam danos emocionais, perturbação do desenvolvimento pleno do ser humano elou diminuição da autoestima por meio do controle ou degradação dos comportamentos, atitudes, crenças e decisões através de ameaças, humilhação, constrangimento e outros meios de limitação ao direito à saúde e à autodeterminação; III) violência sexual, compreendida como conduta que vise i) a praticar ou presenciar relação sexual não consensual por meio de intimidação, coação e outras formas, ii) à indução ao comércio da sexualidade do outro, iii) o impedimento da utilização de métodos contraceptivos, iv) à obrigatoriedade do matrimônio, gravidez, aborto ou prostituição, seja qual for o

Seu nome é em homenagem a Maria da Penha Maia Fernandes, biofarmacêutica natural do Ceará que sofreu consecutivas tentativas de feminicídio cometidas pelo seu marido, o professor universitário Marco Antônio Herredia Viveros, mas que permaneceu na luta pela punição dele e de outros que praticam violências contra a mulher. 
método empregado para tal e v) à interdição de direitos sexuais e reprodutivos; IV) violência patrimonial, que é a retenção, subtração ou destruição de quaisquer bens, documentos ou recursos; e V) violência moral, que inclui a calúnia, a difamação e a injúria (BRASIL, 2006).

A fim de complementar essa disposição, o Conselho Nacional de Justiça (2017) esmiúça o conceito ao afirmar que existe também a violência institucional que, motivada pelas desigualdades sociais, se adere às estruturas de órgãos públicos e privados para excluir pessoas em função dos marcadores de diferença de gênero, raça, condição socioeconômica, etc. Seu impacto na vida das vítimas atravessa os âmbitos físico e psicológico e ecoa grandemente por conta de entrelaçamentos com os outros tipos de violência (LADEIA; MOURÃO; MELO, 2016).

Por fim, para auxiliar conceitualmente esta pesquisa, estão os estudos de violência de Arendt e Bourdieu. Hannah Arendt analisa a violência em suas produções, com foco especial no livro "Sobre a Violência", tendo como experiência de base a Rebelião Estudantil - movimento revolucionário que atuou em diversos países da Europa, Ásia e Américas na primeira metade do século XX (MAGALHÃES, 2008). Para ela, violência é diferente de poder, força ou vigor. Tal diferenciação é defendida como necessária pois, à época, os conceitos eram utilizados como sinônimos já que todos visavam o mesmo fim: a dominação (ARENDT, 2004). Ao estabelecer sua diferenciação com poder e vigor, Arendt não nega sua interdependência. A violência seria, assim, um instrumento do poder: este tende a desaparecer caso aquela perpetue por tempo demasiado, uma vez que, pela sua definição, poder é "correspondente à capacidade de ação conjunta, isto é, da capacidade dos homens para agir em concerto, baseando-se no acordo consensual que emerge no espaço público onde os homens são reconhecidos em sua pluralidade" (MAGALHÃES, 2008, p. 12).

Outro teórico que recorremos aqui é Pierre Bourdieu, sociólogo francês, que, ao discorrer sobre poder e habitus, cunha o termo violência simbólica. Esse tipo de violência é a dominação de uma classe sobre outras através de 
sistemas simbólicos que cumprem a função política de imposição ou legitimação da dominação. Tal violência é tão mais legítima e reconhecida quanto mais invisível e ignorada como arbitrária (BOURDIEU, 1989). Seu modus operandi basea-se na adesão origatória - por conta das estruturas dominantes - pelo dominado à dominação, indispondo, àquele, meios de refletir sobre tal relação. Assim "o efeito da dominação simbólica (...) se exerce através dos esquemas de percepção, de avaliação e de ação que são constitutivos dos habitus e que fundamentam aquém das decisões da consciência (...)" (BOURDIEU, 2002, p. 24). Apesar de tanto Bourdieu como Arendt serem considerados estruturalistas, suas reflexões acerca da violência serão necessárias para as análises posteriores.

\subsection{Performatividade de gênero}

O conceito de gênero é relativamente recente nos estudos sociais e nasce como ferramenta para análises das relações familiares, das distinções sexuais, das experiências generificadas, das participações da mulher em espaços hegemonicamente masculinizados. Seu uso na literatura aparece marcadamente a partir da segunda fase do feminismo, com a obra de Beauvoir - O segundo sexo - a qual discute o feminino para além de determinações biologicistas, mas como construção sócio-histórico-cultural (BEAUVOIR, 1980; FREITAS, 2011). A antropóloga Gayle Rubin participa dessa construção genealógica do gênero pelos seus estudos sobre o sistema sexo-gênero, em que a sociedade transforma a sexualidade definida biologicamente em artifícios para atividade humana, focalizando a alternância e o fluxo entre natureza e cultura (RUBIN, 1993; FREITAS, 2011). Outra autora proeminente é Sherry Ortner, também antropóloga, que problematiza a posição da mulher pela cultura em um sistema naturalizante masculino (ORTNER, 1979). No entanto, a visão permanece binária e restrita, aspectos salientados por Joan Scott, ao defender que o termo gênero é mais adequado, pois amplia a perspectiva das relações sociais, incluindo não apenas a ideia de parentesco, mas também em outras esferas como a discursiva, histórica e política (SCOTT, 1995; FREITAS, 
2011). Ela, ademais, rejeita a determinação sexual do ser humano em sociedade por características morfofisiológicas. Continuando as investigações sobre gênero, aparece no cenário Judith Butler e sua noção de performatividade de gênero, buscando romper com a proposta de construção social da sexualidade para avançar em uma construção discursiva de gênero (FREITAS, 2011).

A autora constrói as ideias de performatividade a partir do desejo de contrapor aos binarismos hegemônicos sociais, ou seja, à questão das diferenças sexuais, utilizando-se, para tanto, de múltiplas fontes: Beauvoir, Nietszche, Hegel, psicanálise lacaniana, Deleuze, Derrida, Sartre, Kristeva, Austin, Morrison, entre outras(os) autoras(es) (BATISTA, 2007).

Essencialismos e binarismos foram paradigmas que Butler buscou desconstruir com a ideia de performatividade de gênero, buscando desnaturalizar, colocar em xeque o ser feminino e o ser masculino, como se houvesse apenas essa ontologia da existência corpórea. Gênero, portanto, não é algo que somos, mas sim o que fazemos ou desfazemos (SALIH, 2017). Não se constata, quando nasce uma pessoa, se é menina ou menino, mas sim performatiza-se um gênero, desde o chá de revelação, passando pela decoração do quarto e as roupas que serão dadas às crianças. $O$ aparecimento desse corpo (ou mesmo da expectativa de seu nascimento biológico) provoca manifestações e expressões, condicionadas por normas obrigatórias que o definem geralmente entre duas opções de ser em função principalmente de determinismos biológicos e cromossômicos (BUTLER, 2009) e isso se perpetua em diversos momentos discursivos na nossa vida classificada pelo gênero: registro civil para acesso a direitos, adoção de crianças - em que a pessoa adulta precisa escolher qual "sexo" quer - a seção da loja onde vamos encontrar a peça que estamos desejando adquirir (BUTLER, 2018).

Butler afirma que corpos são discursos, ou seja, discursos que habitam nossos corpos, como corpos habitam discursos; de que eles, os discursos e as normas, nos "produzem", declarando os modos de vida que adquirimos ao longo do tempo e podendo oportunizar formas de contestá-los (BUTLER, 
2018); por meio de atos performativos, os corpos são considerados legítimos ou não pela faceta regulatória da norma. Assim "o gênero passa a ser uma performance do que aparenta ser, não havendo um por trás desta performance, e nem das próprias identidades de gênero. As identidades são construídas performativamente por seus atos e gestos atribuídos como sua consequência" (BATISTA, 2007, p. 84). Em outras palavras, ser homem é efeito da performance masculina e o mesmo vale para quaisquer outros desejos ontológicos. O sujeito está nele desde sempre e toda sua ação e mesmo transformações só podem acontecer em um campo inteligível de forças e regulações (BUTLER, 2003).

Para Butler, o corpo não existe essencialmente ou anteriormente às culturas, mas sim é algo da ordem do fazer - e não do ser - que se repete em nosso cotidiano e significa nosso corpo, como as roupas, a entonação da voz, as cores e posições corporais usadas, ou seja, são atos performativos corporais e linguísticos estilizados e citacionalizados que performatizam o gênero (BUTLER, 2003; BORBA, 2014). E esse fazer gênero vem a nós primariamente pela norma aplicada a um outro, mas que permanece em nós como uma fantasia eterna, que parece ter sempre estado ali, mesclando as normas do outros com nossas próprias (BUTLER, 2018)

Tal fazer performativo requer: I) um ato aceito e inteligível socialmente, que inclui a enunciação de certas palavras e a cenificação de certos comportamentos; II) pessoas e circunstâncias particulares e apropriadas para invocação do procedimento; e III) que o procedimento seja executado por todos de forma completa e corretamente. À medida que se repete, essa performatividade se torna "real" e "natural", cristalizando-se até parecer uma substância, criando a ilusão de que está na essência do sujeito, anterior à ação (BUTLER, 2003; MINGO; MORENO, 2017), gerando um efeito ontológico.

Ademais, a performatividade se diferencia da performance por ser um processo global de construção de gêneros, constituído por ações linguístico-semióticas que atravessam as práticas sociais, pois tem o poder de estruturá-las e, ao mesmo tempo, é estruturado por elas, enquanto que a performance é 
localizada, micropoliticamente, no público (MINGO; MORENO, 2017). A performance, portanto, é possibilitada, potencializada e limitada pela performatividade, que, por sua vez, é descontínua, repleta de fissuras e quebraduras. De toda forma, essa cena performática não é um ato livre de expressão teatral, pois é regulada por uma estrutura rígida discursivolinguística repleta de constrangimentos (BORBA, 2003; BUTLER, 2003). A subversão da cena apenas acontece no interior das práticas de significação, sendo necessário negociar com as formas de poder que condicionam as vidas (BUTLER, 2009).

\title{
4.4 Interseccionalidade
}

Elaborado a partir das experiências do movimento negro feminista norteamericano do final do século $\mathrm{XX}$, o conceito de interseccionalidade busca auxiliar na análise abrangente, histórica e empiricamente, das inter-relações entre as formas de diferenciação (BRAH, 2006). A

\begin{abstract}
interseccionalidade remete a uma teoria transdisciplinar que visa apreender a complexidade das identidades e das desigualdades sociais por intermédio de um enfoque integrado. Ela refuta $o$ enclausuramento e a hierarquização dos grandes eixos da diferenciação social que são as categorias de sexo/gênero, classe, raça, etnicidade, idade, deficiência e orientação sexual. $O$ enfoque interseccional vai além do simples reconhecimento da multiplicidade dos sistemas de opressão que opera a partir dessas categorias e postula sua interação na produção e na reprodução das desigualdades sociais (BILGE, 2009, p. 70).
\end{abstract}

Kimberle Crenshaw discute que a interseccionalidade funciona como sobreposição de identificações (ou marcadores sociais) de grupos de pessoas. Assim um grupo que tenha seus direitos civis e humanos desrespeitados, como acontece com o grupo de mulheres, possui diferenciações intragrupos - não são só mulheres, são mulheres negras, imigrantes, com deficiência, trans, entre outros marcadores. Considerando o percurso histórico, as nomeações são rechaçadas por eixos de discriminação: sexismo, racismo, transfobia, 
xenofobia, que são "os sulcos profundos que podem ser observados em qualquer sociedade pelos quais o poder flui" (CRENSHAW, 2004, p. 11).

Os "sulcos" se articulam como estruturas de maneira específica, em determinado momento político, apesar de origens históricas diversas. Portanto quaisquer intervenções no sentido contra-hegemônico precisam ser estrategicamente formuladas no sentido de entender como se interconectam, em vez de compartimentalizar as opressões e enfrentá-las separadamente (BRAH, 2006).

Crenshaw (2016) aprofunda o tema da interseccionalidade ao categorizá-la em estrutural e política. A primeira denomina a convergência de sistemas estruturados de poder que impactam na construção de intervenções para grupos alvo das violências. Geralmente as ações de proteção se fecham em determinado marcador seja cultural ou social (mulher, negro, pobre), ignorando outras estruturas de poder transversalizadas. A interseccionalidade estrutural está no cruzamento dessas estruturas que colocam pessoas em situações de opressão múltiplas e qualquer ação unimodal a fim de proporcionar empoderamento destas pessoas será insuficiente para transformação de suas realidades. Por outro lado, a interseccionalidade política chama a atenção para a incompatibilidade de agenda política antirracista, antissexista e outras da mesma ordem. Mesmo quando há o esforço em articular dimensões distintas da discriminação, algo foge do escopo - a diferença intragrupal - que exclui das discussões e dos benefícios certa parcela populacional. Crenshaw (2016) explica que as mulheres negras experimentam o racismo de maneiras nem sempre as mesmas que as experimentadas por homens negros e vivenciam o sexismo de formas nem sempre paralelas às experiências de mulheres brancas, ou seja, as concepções dominantes do antirracismo e do feminismo são limitadas, mesmo em seus próprios termos.

Butler (2015b) reforça essa concepção ao afirmar que nenhum sujeito possui o monopólio sobre perseguir ou ser perseguido - a posição hegemônica em relação ao outro irá depender das multiplicidades de marcadores de diferenças que, naquele instante, privilegiam certos corpos em detrimentos de outros. A 
interseccionalidade rompe com essa posição de compreender pessoas por determinismos identitários - categorias sozinhas não dão conta da complexidade das práticas sociais (DIAS, 2014).

A teoria queer, adotada nesta pesquisa, é necessariamente interseccional, pois motiva a difusão de várias áreas disciplinares como Sociologia, Antropologia, Ciência Política, Saúde Coletiva, Psicologia, Artes, entre outras, para conseguir focar na extensão das corporeidades abjetas, das normalidades que as constrangem e das rupturas epistemológicas coloniais (MISKOLCI, 2009). Colling (2017) aponta que, diferentemente da Espanha, Portugal e Chile, no Brasil não há movimentos sociais ou coletivos que se identifiquem como queer, no entanto essa perspectiva existe no país - ela "está em um novo ou novíssimo movimento (...). Está numa multidão de diferentes que encontramos em escolas, universidades, ruas, locais ocupados, (...) produzindo potentes contradiscursos" (p. 196).

Esse deslocamento para terras brasileiras de um conceito euro-ocidental é feito com bastante discussão. Traduções foram sugeridas como "teoria vadia" e "estudos transviados". De todo modo, e aqui concordamos com Pereira (2012), o que é mais importante nessa disputa linguística e social é aproveitar a potência desse conceito, que causa estranhamento, e comprometer nossa língua à transformação, à escapatória de armadilhas da naturalização e ao próprio estranhar pela (im)possibilidade de tradução.

Sendo assim, vamos utilizar os "óculos" da performatividade, dos conceitos de violência e da interseccionalidade para compreender a construção dos discursos de violência das pessoas participantes da pesquisa, cuja metodologia está descrita a seguir. 


\section{PERCURSO METODOLÓGICO}

\subsection{Tipo de pesquisa}

Esta pesquisa caracteriza-se como qualitativa, já que trabalhamos com significados, motivos, valores e atitudes, ligados a um espaço-tempo "mais profundo das relações dos processos e dos fenômenos que não podem ser reduzidos à operacionalização de variáveis" (MINAYO, 2001, p. 22), exploratória, pois propomos maior familiaridades com o problema, a fim de torna-lo mais explícito e descritivo-interpretativa, uma vez que pretendemos descrever fatos e fenômenos sem contudo deixar de lado um exame crítico das informações (SILVEIRA; CÓRDOVA, 2009).

\subsection{Instrumento de coleta de corpus}

Para possibilitar a apreensão desse universo de sentidos, foram realizadas entrevistas com roteiro semiestruturado conforme Apêndice 1.

Para chegar até às pessoas participantes, foi utilizada a técnica de amostragem não-probabilística conhecida como bola de neve. Seu uso é particularmente adequado quando o grupo é de difícil acesso ou quando não há dados suficientes para calcular o universo de eventos. Assim, utiliza-se uma cadeia de referências, que se inicia com informantes-chave, aos quais é solicitado indicações de pessoas com características desejadas (VINUTO, 2016). Para esta pesquisa, enviamos uma carta de apresentação para movimentos sociais e estudantis, organizações não governamentais e coordenações de projetos de extensão universitária, todos ligados à garantia de direitos LGBT+ atuantes na Região Metropolitana de Belo Horizonte (RMBH), considerados nossos informantes-chave. A carta continha a proposta da pesquisa, breve currículo da equipe pesquisadora e solicitação de indicações de pessoas maiores de dezoito anos e que se identificassem como lésbica, gay, bissexual, travesti ou transexual para que fosse realizada a entrevista. 
Após receber as indicações, entrei em contato com cada pessoa, explicando a pesquisa, seus objetivos, a forma como seria realizada a entrevista, escolha do local em função das necessidades da pessoa e esclarecimento de dúvidas. Caso a pessoa demonstrasse interesse, marquei um momento para conversarmos e, presencialmente, repeti os objetivos e a forma de condução da pesquisa, a garantia do anonimato e ocorreu a assinatura do Termo de Consentimento Livre e Esclarecido (Apêndice 2).

Essa pesquisa foi aprovada pelo Comitê de Ética em Pesquisa do Instituto René Rachou da Fundação Oswaldo Cruz sob o número CAAE 63857317.6.0000.5091 e parecer de aprovação n. 1.925.485.

\subsection{Participantes da pesquisa}

Por meio da Técnica Bola de Neve, entramos em contato com três movimentos sociais e estes nos retornaram com um ou dois nomes de pessoas que correspondiam ao nosso grupo de interesse para a pesquisa. Entramos em contato com cada uma e, após o aceite em participar da pesquisa e a realização da entrevista, solicitamos que indicasse outra pessoa que poderia participar. Assim chegamos ao número de nove pessoas, conforme Tabela 1.

Buscamos, à medida que as indicações aconteciam, entrevistar pessoas que tivessem diferentes ontologias, com o objetivo de apreender vivências de distintos percursos biográficos. Além disso, o grupo foi definindo-se ao passo que nos aproximávamos ao máximo do objeto pesquisado (violências e estratégias de enfrentamento) sem, com isso, pretender saturá-lo (MINAYO, 2017), de modo que nove entrevistas foram consideradas suficientes para possibilitar análise profunda - condizente com a riqueza dos relatos considerando, igualmente, o cronograma possível para a conclusão do mestrado. 
Tabela 1 - Perfil das pessoas entrevistadas segundo idade, gênero, orientação sexual, raça/cor/etnia, escolaridade e local de residência.

\begin{tabular}{|c|c|c|c|c|c|c|}
\hline Codinome & Idade & Gênero & $\begin{array}{l}\text { Orientação } \\
\text { sexual }\end{array}$ & $\begin{array}{l}\text { Raça/Cor/ } \\
\text { Etnia }\end{array}$ & Escolaridade & Residência \\
\hline P1 & 29 & $\begin{array}{l}\text { Homem } \\
\text { cis }\end{array}$ & Gay & Negro & $\begin{array}{l}\text { Pós- } \\
\text { graduação } \\
\text { completa }\end{array}$ & RMBH \\
\hline $\mathrm{P} 2$ & 28 & $\begin{array}{l}\text { Homem } \\
\text { cis }\end{array}$ & Gay & Negro & $\begin{array}{l}\text { Superior } \\
\text { incompleto }\end{array}$ & RMBH \\
\hline P3 & 21 & $\begin{array}{l}\text { Não- } \\
\text { binárie }\end{array}$ & Lésbica & Branca & $\begin{array}{l}\text { Superior } \\
\text { incompleto }\end{array}$ & Interior \\
\hline P4 & 21 & $\begin{array}{l}\text { Mulher } \\
\text { cis }\end{array}$ & Lésbica & Negra & $\begin{array}{l}\text { Superior } \\
\text { incompleto }\end{array}$ & RMBH \\
\hline P5 & 21 & $\begin{array}{l}\text { Homem } \\
\text { trans }\end{array}$ & Bissexual & Branco & $\begin{array}{l}\text { Superior } \\
\text { incompleto }\end{array}$ & $\mathrm{RMBH}$ \\
\hline P6 & 22 & $\begin{array}{l}\text { Homem } \\
\text { cis }\end{array}$ & Gay & Negro & $\begin{array}{l}\text { Superior } \\
\text { incompleto }\end{array}$ & $\mathrm{RMBH}$ \\
\hline P7 & 28 & $\begin{array}{l}\text { Homem } \\
\text { cis }\end{array}$ & Gay & Negro & $\begin{array}{l}\text { Superior } \\
\text { incompleto }\end{array}$ & RMBH \\
\hline P8 & 22 & $\begin{array}{l}\text { Mulher } \\
\text { cis }\end{array}$ & Lésbica & Negra & $\begin{array}{l}\text { Superior } \\
\text { incompleto }\end{array}$ & RMBH \\
\hline P9 & 23 & $\begin{array}{l}\text { Mulher } \\
\text { cis }\end{array}$ & Lésbica & Branca & $\begin{array}{l}\text { Superior } \\
\text { incompleto }\end{array}$ & $\mathrm{RMBH}$ \\
\hline
\end{tabular}

Ao entrar em contato com os movimentos sociais e, posteriormente com as primeiras pessoas entrevistadas, não foi explicitado qual nível de escolaridade nem a idade máxima de quem poderiam indicar. No entanto é perceptível que o grupo participante da pesquisa foi formado por pessoas entre 21 e 29 anos, que estão ou já passaram pelo ensino superior. Algumas hipóteses podem ser levantadas para explicar esse cenário: I) pessoas com formação universitária estão mais propensas a participar de pesquisas pois podem ter atuado como 
pesquisadoras em seus percursos acadêmicos e tenham desenvolvido solidariedade à pesquisa ou compreensão aprofundada do que é ciência; II) ao apresentarmos a pesquisa, os movimentos sociais podem ter depreendido que pessoas com formação universitária seriam mais "preparadas" para participar da entrevista; III) é no ambiente universitário que as pessoas possuiriam maior abertura para explorar e/ou conhecer suas identidades de gênero e orientações sexuais, devido a debates, eventos e estudos desse tema.

As identidades das(os) participantes da pesquisa demonstram uma matriz de interseccionalidades, em que cada pessoa possui diversos marcadores que podem, de acordo com a cena enunciativa, colocá-las em distintas posições nas relações de poder instituídas. Essas características serão melhor analisadas no momento dos resultados.

\subsection{Método de análise}

As entrevistas foram gravadas, transcritas e analisadas sob a perspectiva da Análise do Discurso Crítica (ADC), de vertente britânica desenvolvida e proposta por Norman Fairclough (2001), inserida em um conjunto de ideias cunhadas como Teoria Social do Discurso (TSD), cuja tese inicial é que há relações dialéticas entre a vida social e os discursos, ou seja, discursos constroem e constituem relações sociais e não apenas as refletem (FAIRCLOUGH, 2001); discursos são constituídos e constituintes da vida social. Alicerçada na postura crítico-realista, a TSD busca oferecer suporte científico para pesquisas sobre o funcionamento dos discursos na instauração, manutenção e/ou superação de problemas socialmente construídos (RAMALHO; RESENDE, 2011).

A investigação científica pela TSD baseia-se em "análises de mecanismos causais e de efeitos potenciais em contextos particulares, com atenção voltada para causas e efeitos envolvidos em relações de poder" (RAMALHO; RESENDE, 2011, p. 104). Para essas autoras, a TSD é muito útil em situações de pesquisa cujo objetivo possa ser mecanismos discursivos e seus efeitos ideológicos e/ou superação de condições assimétricas de poder 
transversalizadas por textos e seus sentidos. Atenta-se, no entanto, para o fato de que não é possível realizar análises totalizantes, definitivas ou imparciais de corpus. A seletividade é inevitável pois buscamos responder determinadas questões (e não outras) sobre certos eventos sociais (e não outros) (RAMALHO; RESENDE, 2011).

A TSD baseia-se na concepção tridimensional do discurso, conforme figura 1, com a proposta de contextualização dos discursos, sempre situados temporal, circunstancial e espacialmente.

Figura 1 - Concepção tridimensional do discurso

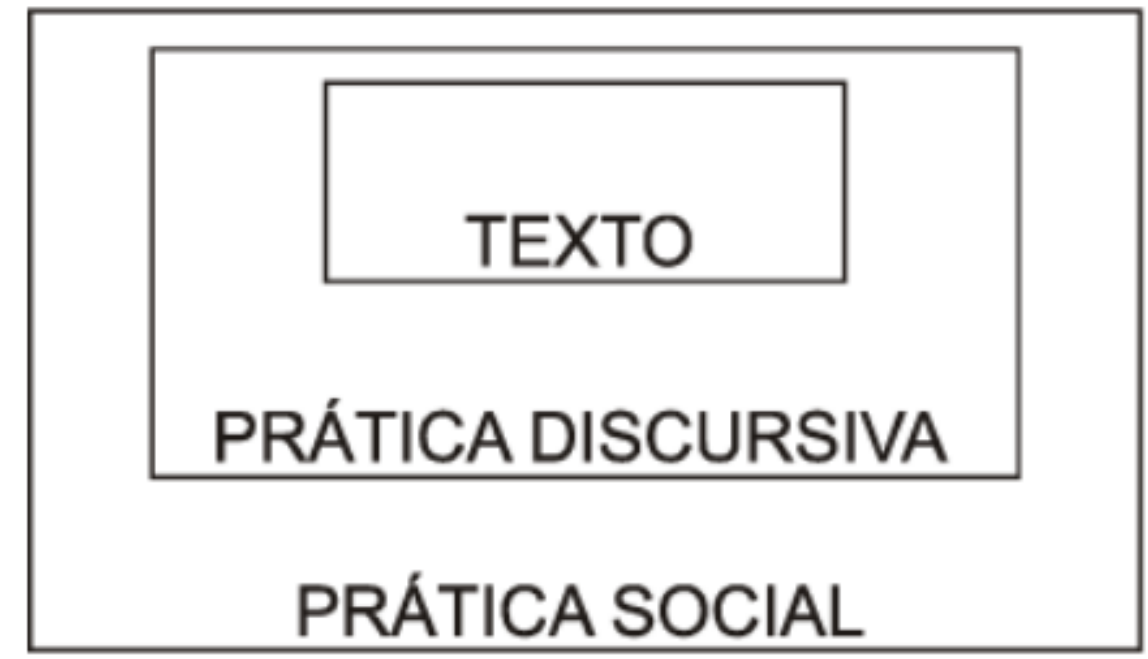

Fonte: FAIRCLOUGH, Norman. Discurso e mudança social. Brasília: UnB. 2001. p. 101.

O procedimento metodológico pela TSD possui três dimensões, de acordo com Fairclough (2001): análise do texto (descrição), análise da prática discursiva (interpretação) e da prática social (explanação crítica). No âmbito do texto, elemento central na figura 1 , analisam-se palavras ou sequências mais longas do texto que possuam significado para a questão de pesquisa. A organização dessa primeira etapa pode ser categorizada em vocabulário, gramática, coesão e estrutura textual. Vocabulário se refere às escolhas e significados lexicais; gramática, às combinações dessas palavras em orações e frases; a coesão é o modo de ligação dessas frases e a estrutura textual compreende propriedades da organização dos textos. 
A esfera da prática discursiva foca nos modos de produção, distribuição e consumo dos textos. Categorias como coerência (relações de sentidos entre partes do texto), intertextualidade (presença explícita ou implícita de outros discursos dentro de um texto) e força (ênfase de partes que possuem forte ligação com o contexto) são úteis nesse momento em que são realizadas as interpretações discursivas. Chega-se, assim, à prática social que "determina os macroprocessos da prática discursiva e são os microprocessos que moldam o texto" (FAIRCLOUGH, 2001, p. 115). No âmbito mais distal da Figura 1 focalizam-se a hegemonia e a ideologia para interpretar a prática social do texto analisado. Ideologia é entendida como conjunto de significações e/ou construções da realidade que são realizadas nas várias formas das práticas discursivas e que contribui para as relações de produção, reprodução ou transformação das dominações sociais e das relações de poder. Já a hegemonia é "poder sobre a sociedade como um todo de uma das classes economicamente definidas como fundamentais em aliança com outras forças sociais, mas nunca atingido senão parcial e temporariamente (FAIRCLOUGH, 2001, p. 122). Nesta última etapa, são produzidas as explanações críticas acerca do objeto estudado.

Resumidamente, Ramalho e Resende explicam que

(...) pesquisas orientadas pela ADC partem da identificação de um problema social com aspectos semióticos. Definida a preocupação de pesquisa, seguese à identificação de elementos que representem obstáculos para a superação do problema, por meio de três tipos de análise: análise da conjuntura, análise da prática particular e análise do discurso. (...) Nas duas primeiras etapas, investigam-se redes de práticas (ou conjunturas) em que se localiza o problema de cunho semiótico, assim como a prática particular em estudo. (...) As análises da conjuntura e da prática particular garantem a contextualização da análise discursiva (...). Na análise do discurso (...) pesquisam-se conexões entre mecanismos discursivos e o problema do foco." (RAMALHO; RESENDE, 2011, p. 107-108). 
Para auxiliar a análise, foram utilizados os Sistemas de Transitividade de Halliday (1985/1994 apud NININ, 2009) em que é possivel identificar os processos, seus respectivos participantes e as circunstâncias associadas. Através do esquema da figura 2 , podemos apreender significados das experiências das pessoas participantes da pesquisa sobre o mundo, sobre suas ações e especialmente sobre suas construções de rede de verdades sobre a violência e as estratégias de enfrentamento.

Figura 2 - Processos, participantes e circunstâncias associadas.

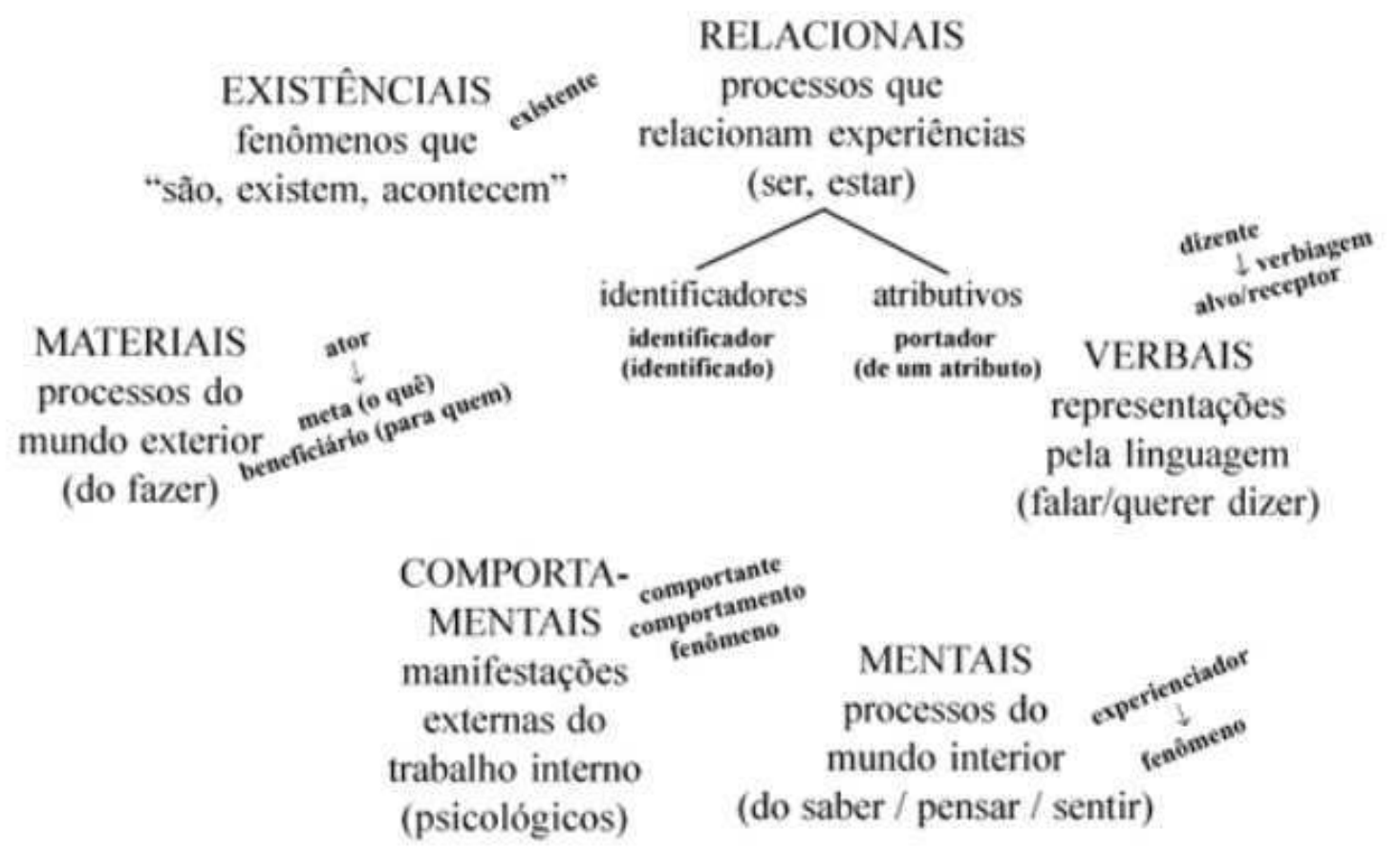

Fonte: NININ, Maria Otilia Guimarães. A atividade de observação nas práticas de orientação a professores: uma perspectiva crítica. DELTA, São Paulo, v. 25, n. 2, p. 359, 2009.

Para utilizar metodologicamente a TSD, não é necessário lançar mão de todas as categorias possíveis, pois cada corpus terá elementos próprios a partir da escolha de foco do processo de pesquisa. Para esta pesquisa, foram selecionadas as categorias Vocabulário, Gramática, Intertextualidade e Interdiscursividade, Hegemonia e Ideologia. O Vocabulário trata 
primordialmente das palavras individuais, no entanto vai além de seus significados dicionarizados. As palavras implicam processos de significação do mundo que ocorrem temporalmente e para grupos sociais de formas diferentes. Trabalharemos aqui com significados e sentidos das palavras, especialmente como tais sentidos entram em disputas mais amplas pela posição dinamicamente hegemônica e o uso de metáforas, uma vez que demonstram as implicações políticas e ideológicas dos discursos (FAIRCLOUGH, 2001). A categoria Gramática possibilita aprofundar na compreensão das orações, conjuntos de significações ideacionais, interpessoais e textuais, que as pessoas escolhem de acordo com o desejo de formação ontológica, de construção das relações sociais e de afirmação/negação de sistemas de conhecimentos e crenças. $\mathrm{Na}$ oração estabelecem-se atores, processos, metas, identidades, representações que atravessam e são transversalizadas pelas ordens discursivas e sociais (FAIRCLOUGH, 2001).

Transitando para o campo das práticas discursivas, há a Intertextualidade e Interdiscursividade. A intertextualidade é a propriedade dos textos em serem cheios de fragmentos de outros textos, seja delimitados explicitamente por aspas ou mesclados no interior do texto, de forma a provocar ecos, contradições e outros efeitos discursivos (FAIRCLOUGH, 2001). Quando nitidamente identificados, dizemos que existe intertextualidade manifesta, pois o discurso é heterogêneo, cheio de falas de outros atores, como essa dissertação e suas citações. Por outro lado, a interdiscursividade é a intertextualidade constitutiva, não explícita, a qual, no discurso, é apresentada apenas por vestígios, metáforas, presença/ausência de vozes sociais ou ainda por pressuposições. Nesse momento da ADC, é importante compreender quais ordens dos discursos estão fazendo-se presentes, ou seja, quais conjuntos de termos e significados que determinam, hegemonicamente e temporariamente, práticas sociais (LOPES, 2018). "Pode-se considerar uma ordem do discurso como a faceta discursiva do equilíbrio contraditório e instável que constitui uma hegemonia" (FAIRCLOUGH, 2001, p. 123).

Chegamos à Hegemonia como categoria analítica que possibilita identificar liderança e/ou dominação de escopos sociais como econômico, político, 
cultural e ideológico (FAIRCLOUGH, 2001). Estabelece-se hegemonia a partir de alianças, prevalecendo certos grupos em relações assimétricas de poder, imputando naturalização a valores, símbolos, normas e demais especificidades do grupo hegemônico de modo a manter sua posição (LOPES, 2018). A Ideologia atravessa todo o modelo analítico, materializando-se por meio das práticas discursivas e interpelando sujeitos construtores do e construídos pelo discurso. Fairclough (2001, p. 117) entende ideologia como

significações/construções da realidade (o mundo físico, as relações sociais, as identidades sociais) que são construídas em várias dimensões das formas/sentidos das práticas discursivas e que contribuem para a produção, reprodução ou a transformação das relações de dominação.

Assim como acontece com a hegemonia, a ideologia funciona muito bem quando embutidas nas práticas discursivas, naturalizando-se e atingindo 0 status de senso comum. Assim a ideologia está presente tanto nas estruturas sociais como nos processos e eventos, dialeticamente móvel, com vistas à manutenção ou transformação do instituído (FAIRCLOUGH, 2001).

\subsection{Ferramenta de análise}

Para auxiliar na análise textual, foi utilizado o software brasileiro Kitconc versão 4.0. Esse programa proporciona a exploração do corpus textual de modo a fornecer a frequência das palavras que mais se repetem, sua predominância no texto, com quais outras palavras determinados termos se ligam e onde mais aparecem (MOREIRA FILHO, 2008). 
Figura 3 - Telas de trabalho do software KitConc, 2018.

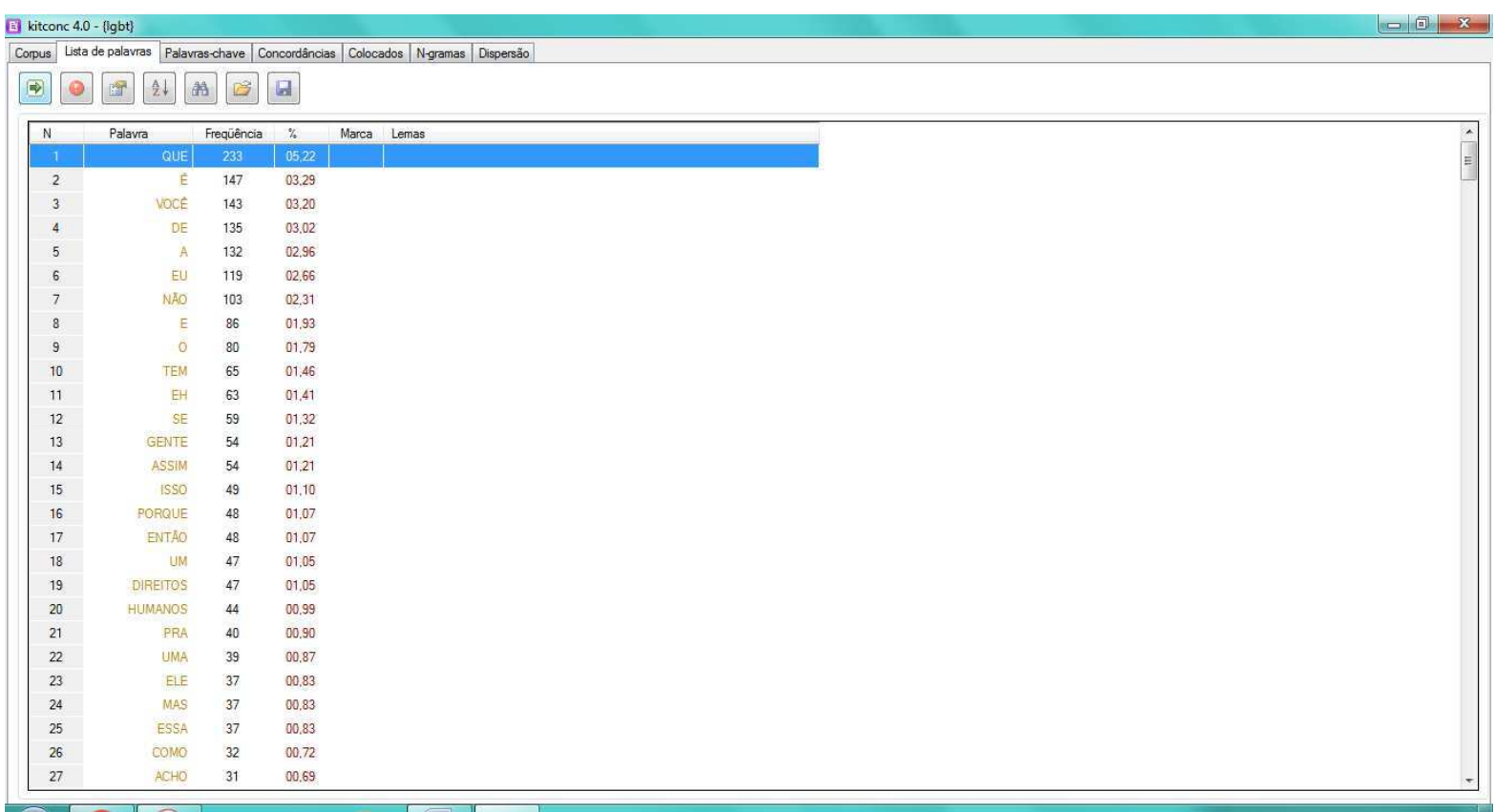

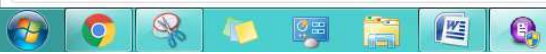

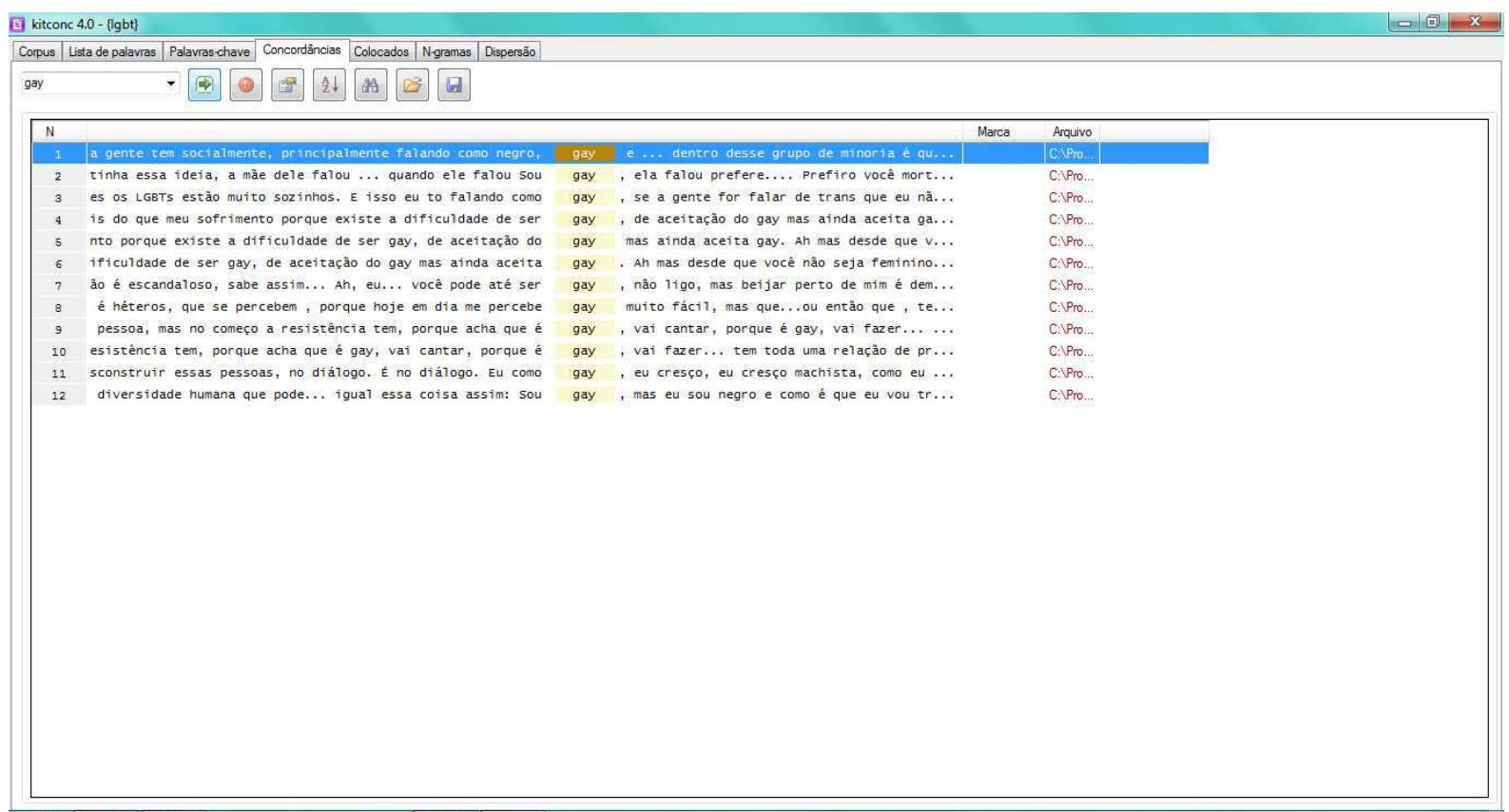

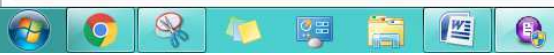

O uso do software possibilitou rápida visualização do corpus no que tange o vocabulário, as relações estabelecidas entre sintagmas das orações e recorrência de grupos. A análise qualitativa pôde ser complementada com aspectos quantitativos, uma vez que o KitConc possibilitou calcular a 
frequência absoluta e relativa dos termos de interesse para a pesquisa em relação ao todo, além do indicador de chavicidade.

\subsection{Procedimento interpretativo}

Em busca de assumir estratégias de pesquisas participativas (CAMPOS, 2011), após interpretarmos as narrativas, voltei às pessoas entrevistadas para compartilhar com elas o que nós entendemos daquele momento e, a partir do encontro e de novas reflexões, construir novas interpretações - agora não sobre elas, mas com elas. Assim, esse comprometimento de construir práticas de pesquisa dialógicas é feito mediante compartilhamento de análises e resultados com as pessoas participantes, criando espaços de negociação das interpretações e ouvindo-as também para escrever as conclusões desse processo. Segundo Resende (2008, p. 107), "A democratização do conhecimento gerado pela pesquisa e a negociação das interpretações só podem ser efetivas se os métodos para tanto forem definidos de acordo com o grupo e com seus interesses específicos na pesquisa". Um terceiro encontro, como proposta de intervenção, será realizado, após a aprovação dessa dissertação, para conversar sobre possíveis encaminhamentos dos conhecimentos produzidos para intervenções. Ao conduzir dessa forma, tentamos rejeitar a violência interpretativa já que "Ninguém é mão-de-obra para o pensamento de outrem. Todos pensam. Todos ganham" (CAMPOS, 2011, p. 1284). 


\section{RESULTADOS E DISCUSSÃO}

A primeira parte da seção será dedicada aos resultados e análises do objetivo específico primeiro: descrever e analisar as violências de gênero e de orientação sexual vivenciados pelas(os) participantes da pesquisa.

\subsection{Sobre violências}

Primeiramente solicitei às(aos) entrevistadas(os) que indicassem três palavras que viessem à mente delas(es) quando ouvissem o verbete violência, para que eu pudesse compreender inicialmente como representariam de forma imediata o que esse tema significa para elas(es).

Das palavras que vieram dessa primeira questão, é possível agrupá-las em três grupos, conforme tabela 2. Percebeu-se que a violência era representada, para elas(es), através de três grandes categorias: processo, produto e sujeito.

Tabela 2 - Grupos de significados das palavras relacionadas à violência, quantidade de repetição e respectivos índices de chavicidade ${ }^{4}$.

\begin{tabular}{|l|l|l|}
\hline PROCESSO & PRODUTO & SUJEITO \\
\hline Ignorância(3)(26,86) & Medo (2)(93,02) & Travesti(1)(65,67) \\
\hline Preconceito (1)(54,17) & Agressão (2)(38,38) & Mulher(1)(18,26) \\
\hline Intolerância (1)(--) & Abuso sexual (1)(48,20) & Negros (1)(--) \\
\hline Não conhecimento (1)(--) & Desrespeito (1)(16,82) & \\
\hline & Repressão (1)(14,33) & \\
\hline & Constrangimento (1)(--) & \\
\hline
\end{tabular}

Alguns termos não apresentaram índice de chavicidade e isso significa que a palavra não é típica do corpus analisado. No entanto foram considerados aqui por estar fortemente ligados com as questões de pesquisa. 


\begin{tabular}{|l|l|l|}
\hline & Conversas (1)(--) & \\
\hline & Humilhações (1)(--) & \\
\hline & Limitação (1)(--) & \\
\hline & Maus tratos (1)(--) & \\
\hline & Morte (1)(--) & \\
\hline & Traumas (1)(--) & \\
\hline & Violação de direitos (1)(--) & \\
\hline
\end{tabular}

$\mathrm{Na}$ coluna Processo, estão reunidos os itens lexicais que estão ligados aos processos violentos, geralmente associados às pessoas que agridem. Já no Produto, estão os itens referentes aos possíveis resultados dos atos de violência sofridos pelas vítimas. Por fim, a terceira coluna nomeia os alvos das violências. A ordem das palavras indica, por coluna, o número de repetições encontradas, o grau de representatividade que tais termos possuem em relação às entrevistas, característica denominada chavicidade (ODORISSIO, 2017) e por fim em ordem alfabética. Por exemplo, medo foi a palavra mais significativa do corpus, pois, apesar de ter sido a mais citada, possui alto índice de chavicidade, no valor de 93,02. A chavicidade é uma medida estatística, geralmente calculada pelo teste qui-quadrado que busca mensurar a significância da diferença entre a frequência de palavras esperadas de um corpus e sua frequência observada. O resultado final da soma dos valores esperados e observados será a chavicidade do termo.

O conceito da violência, pela perspectiva subjetivista de Minayo, parece estar mais ligado aos itens lexicais designados em processo, uma vez que intolerância, não conhecimento, ignorância e preconceito são, também, da ordem do sujeito. Digo também já que não é plausível que imputemos unilateralmente certa falta de atributos à pessoa sem especificar em quais 
contextos ela viveu e quais foram as oportunidades oferecidas a ela para que não fosse ou deixasse de ser adjetivada pelas palavras da primeira coluna.

Quando as pessoas entrevistadas me dizem essas palavras relativas à ideia de processo, elas não indicam quem pratica a violência: pode ser um sujeito que age violentamente, obedecendo cegamente a ordens superiores; mas pensemos também no hipersujeito que é "aquele que compensa a perda de sentido (caso precedente) pela sobrecarga, o excesso, dando-lhe um sentido novo, ideológico, mítico, religioso" (WIEVIORKA, 2006, p. 1150); há também sujeitos flutuantes que demandam pela violência pois não encontram outros meios de serem atores na sociedade; pode ser igualmente um sujeito que nega o outro para viver (o antissujeito), sendo condição sine qua non para a construção da própria subjetividade, ou ainda o sujeito em sobrevivência que se sente ameaçado ao existir e, para resistir, age de maneira violenta (WIEVIORKA, 2006).

Mesmo não podendo definir que sujeito violento é esse, percebe-se que a primeira coluna está atravessada pela ideia de que o sujeito possui capacidade de se construir, de dominar, de alguma forma, sua experiência e de produzir escolhas, muito parecido com a tônica das práticas discursivas liberais, em que o sujeito é livre para escolher e competir pelos melhores recursos sociais. Não são atributos considerados naturais ao ser humano - pelo contrário, são processos em que as pessoas têm certa autonomia de uso e de afetação. A pessoa intolerante pode não a ser mais ou o não conhecimento pode deixar de caracterizar o sujeito violento pela tomada de ações que visem sua superação. O discurso da violência enquanto processo é presente nas falas de P2 (homem, cis, negro, metropolitano), P9 (mulher, cis, lésbica, branca, metropolitana) e P5 (homem, trans, branco, metropolitano), sendo mais fortemente marcado nas duas primeiras entrevistadas.

A segunda coluna enumera alguns dos resultados das ações violentas: agressão $(38,38)$, medo $(93,02)$, abuso sexual $(48,20)$, entre outros, com os maiores níveis de chavicidade do corpus. Definir violência, a partir dos seus produtos, coaduna-se às conceitualizações mais institucionalizadas como por 
exemplo as da OMS e do aparato jurídico brasileiro. A violência, portanto, é algo que acontece que "cause morte, sofrimento físico, sexual ou psicológico, lesão, dano moral ou patrimonial no âmbito domiciliar, familiar ou íntimo" (BRASIL, 2006, p. 2) ou "que resulte ou tenha grande possibilidade de resultar em lesão, morte, dano psicológico, deficiência de desenvolvimento ou privação" (OMS, 2002, p. 5). Tal institucionalização casuística é útil para a responsabilização do ato. Ao delimitar a violência pelos seus resultados, fica palpável percebê-la e apontar o autor da lesão ou do dano. Um soco que uma pessoa possa dar em outra, por exemplo, é resultado visível e material de um choque entre dois corpos, sendo um deles portador tanto da capacidade de socar quanto da intencionalidade de cometer tal ato. No entanto o soco precisa ser conhecido como algo violento para haver o reconhecimento do ato como violência - se o soco for justificável por alguma característica da pessoa que o recebe ou por uma condição de direito de quem agride, não haverá, portanto, violência e, consequentemente, ações para coibi-la.

Aspectos físicos dos produtos como lesão, morte e agressão geralmente são os elementos mais associados à violência, como pode ser percebido nas definições da OMS e do aparato jurídico-brasileiro, assim como na frequência de ocorrência nas entrevistas.

No entanto, produtos mais abstratos como humilhações, constrangimentos e desrespeito aparecem de modo mais variado nas entrevistas: pode indicar que, para a comunidade LGBT+ universitária, a violência manifesta-se antes por formas não físicas (psicológicas, simbólicas, verbais) do que materiais, dificultando a responsabilização do agressor pelo ato. Essa difusibilidade da violência, que deixa marcas, mas não impressões digitais, imputa a todos e, portanto, a ninguém, a necessidade de rever posicionamentos, atitudes e a ressarcir danos causados às vítimas. Aqui estão presentes as falas da maioria do conjunto de entrevistadas: P1, P3, P5, P4, P6 e P7. Observamos que pessoas com diferentes marcadores (trans, cis, lésbica, gay, negras, brancas), corroboram com a definição simbólica (não física) da violência contra pessoas LGBT+. Essa definição de violência, antes "por coração e mentes", ou seja, por discursos, trata-se de atos performativos de violência que passam a habitar 
esses corpos, assim como os corpos habitam esses discursos de humilhação, constrangimentos e insultos.

A última coluna nomeia os sujeitos vitimados, presente unicamente na entrevista de P8: lésbica, negra, mulher. A questão que reside nessa nomeação é: por que estes e não outros?

Com o auxílio de Butler (2015a; 2015b), é possível compreender que travestis, negros(as) e mulheres são alvos ethoicos de uma sociedade normatizada pela ideologia anacrônica de homens cis brancos. A ordem em que as palavras foram ditas por P8 (Travesti, negro, mulher) também pode indicar que a violência aumenta à medida que tais matizes identitárias cruzam-se, se interseccionam, pois os fluxos de poder são mais fortes em corpos não legitimados como humanos, ou seja, como abjetos (BUTLER, 2011) vulnerabilizando-os e forçando/mantendo o não reconhecimento de suas experiências como violentas. Tornam-se corpos-lixo (BENTO, 2017). Isso impacta não apenas nas vivências cotidianas da comunidade LGBT+, mas também na formulação de políticas públicas que visem à promoção de sua saúde: apesar de haver reivindicações pelo reconhecimento da necessidade de intervenção pública e estatal na garantia do direito à saúde das mulheres, das pessoas negras e da comunidade LGBT+ desde o século $X X$, suas políticas nacionais foram promulgadas apenas nas últimas décadas (2004, 2009 e 2011, respectivamente) (BRASIL, 2011; 2017, VIEIRA, 2015b).

Continuo a entrevista e pergunto, agora diretamente e sem limitação de palavras, o que é violência. As respostas foram aqui organizadas pelos tipos de participantes dos processos de violência e respectivo foco discursivo.

As falas a seguir definem violência por processos materiais ou relacionais cujos atores ou portadores são pessoas que agridem.

- "[violência] talvez é uma questão interna muito difícil que a pessoa passa (...) pode ser traumas ou coisas que acontecem com a pessoa, pode ser uma falta de compreensão, mesmo uma ignorância, uma falta da informação." (P5) 
Neste excerto, o entrevistado caracteriza a violência como uma questão interna difícil e a define a partir de certos atributos: traumas, falta de compreensão, de informação e ignorância. Além disso modaliza sua afirmação com léxicos de imprecisão como talvez e pode ser. Imputa à subjetividade da pessoa que agride possíveis causas da violência, bem semelhante às considerações de Minayo (2006), que também levanta esse imbricamento do sujeito em relação à violência. Para ela,

É preciso dar relevo à lógica da perda e da sobrecarga, dos excessos e da falta de sentidos que pervertem, preservam ou também asseguram a sobrevivência dos sujeitos (...). Ao colocar a subjetividade na discussão da violência, ressalto a importância de levar em conta a micropolítica, mostrando que ela afeta existências singulares e coletivas (MINAYO, 2006, p. 22).

Essa micropolítica referenciada por Minayo advém dos escritos de Deleuze e Guattari sobre uma forma de atividade que acontece no cotidiano das relações sociais, guiada pelos interesses individuais e constrangida pelas linhas de força (FERREIRA NETO, 2015). Assim, a micropolítica agiria como um modelo ou pista explicativa da violência que fosse além de marcadores estruturais ou biológicos, adentrando nos processos de subjetivação das pessoas que ora são violentas, ora são violentadas. $\mathrm{P} 5$, ao falar da falta de informação e do trauma, exemplifica essas linhas de força que regulam a liberdade individual para agir ou não violentamente. É perceptível que discursos liberais e biomédicos misturam-se a outros que não podemos apreender apenas por essa fala para que P5 defina violência. Já P8 entende violência por outra via discursiva:

- "eu acho que é uma construção estrutural que a sociedade enquanto maioria oprime, reprime e ela não é só física, ela também pode ser moral, a violência pode ser um olhar (...) ela transparece de várias formas (...) pode ser física e pode ser moral. Eu acho que quando eu penso em violência, eu penso nisso, sabe, algo que é uma agressão feita por algum, algum opressor em relação a uma minoria. Seja alguém que ele acha que pode dominar (...). Alguém que possa achar que pode dominar o outro." (P8) 
Neste excerto, a entrevistada está problematizando (eu acho, eu penso), refletindo sobre a forma como define a violência, por meio dos processos mentais acho e penso, e recai no agressor também, mas já indica que há dois tipos de violência: física e moral. Além disso, parte de uma prática discursiva sociológica estruturalista de que há uma polarização entre uma sociedade dominante que oprime, e uma minoria oprimida, dominada. Bourdieu (1989) constrói esse cenário de dominação pelo conceito de violência simbólica, em que o achar que pode dominar é sustentado por uma estrutura que o produz, além de alimentar esse sujeito detentor do saber-(achar)-poder.

- "violência é quando o outro, independente se ela é física ou verbal ou moral, algum tipo de assédio, usa principalmente do poder dela sobre a vítima." (P1)

De outra forma, P1 generaliza, no poder sobre a vítima, sua definição de violência. Exemplifica com os tipos física e moral, inclusive assédio. Esse uso do poder, conforme Butler, forma e delimita o sujeito, em um processo de produção subjetiva violenta (BUTLER, 2014; MORAIS, 2015). Produz a violência como algo relacional: "é quando o outro".

P9, por outra via, aciona práticas discursivas jurídicas para falar comigo sobre violência:

- "violência pra mim é você infringir as leis da sociedade (...) você ultrapassar os limites de respeito com as pessoas e os animais e o meio ambiente (...) se você já ultrapassou o limite, a partir do momento que você está fazendo o mal, isso já é uma forma de ser violento." (P9)

O fato de que as participantes utilizem processos (verbos) diferentes para definir violência (ser, usar, infringir, ultrapassar, dominar) indica que há discursos diferentes que igualmente divergem nos excertos. P8 e P1 compreendem violência pelas relações de poder estabelecidas entre um grupo que detém o poder e domina sobre outro que é alvo desse poder e é dominado. Aqui temos uma sugestão de quem é esse grupo que domina, apesar de sua nomeação é dada pela sua condição relativa: a sociedade enquanto maioria. $\mathrm{E}$ 
é essa sociedade majoritária (que pode não ser maioria numérica, mas maioria dominante) que violenta pela dominação, ou seja, P8 utiliza a expressão "construção estrutural" para definir a violência como uma relação de dominação entre maioria que oprime ou sociedade ou agressor - estabelecendo, assim, uma cadeia sinonímica - e uma minoria dominável. Percebe-se que a noção de violência é unidirecional, da maioria para a minoria, condizente com as ideias de violência de Bourdieu (1989), o qual a define pela aculturação dominante nos dominados, embasado na hierarquização do poder econômico.

Esse poder é lido por Bourdieu como capital, base para as estratégias de manutenção ou melhoramento da posição social (BONAMINO et al., 2010). Há o econômico, o que inclui detenção de fatores de produção e bens comercializáveis, alocados em investimentos de ordem econômica a fim de formar vínculos a curto e longo prazos (BOURDIEU, 1989). Outro capital utilizado para dominação é o social, constituído de relações estáveis em sociedade, principalmente a família, que podem oferecer benefícios e recursos com níveis de qualidade e quantidade suficientes para elevação social (BOURDIEU, 1989; BONAMINO et al., 2010). O terceiro capital - o cultural - é acumulado desde o início do ser social, incluindo domínio de padrões cultos da língua, informações escolares e outros instrumentos compartilhados por familiares que, aos poucos, vão se inculcando no ser e interfere grandemente no desempenho educacional (BOURDIEU, 1989).

Essa aparente fixidez dos atores sociais nas relações de poder é flexibilizada ao fim da fala de P8, quando afirma que quem agride "acha que pode dominar o outro". O processo material dominar é modalizado por um léxico de dúvida, de probabilidade, poder. Portanto a dominação escapa da estrutura e se aloja na percepção individual de possibilidade de poder sobre um outro, em determinadas circunstâncias e com certos atores que propiciam essa performance violenta. Se a pessoa que agride acha que pode dominar o outro, esse outro é percebido como minoria pelo agressor, mesmo que estruturalmente não faça parte de uma classe minoritária. Tal percepção está ligada aos modos de distribuição da precariedade entre grupos com marcadores sociais distintos: como assinala Butler (2018), todos nós somos 
dependentes uns dos outros, porém, em nossa forma social, algumas vidas são mais precarizadas que outras, sendo julgadas como passíveis de uma vida ruim. Percepção semelhante a colocada por $\mathrm{P} 1$, ao afirmar que violência é mediada por um processo material (usar) com a meta sendo vítima. Isso converge com as ponderações de Butler $(2015 b)$ pois o poder não é estabelecido unicamente acima e além do sujeito, como um ser onipotente e onipresente que governa e define quem vai mandar e quem vai obedecer, mas pertencente a um indivíduo, a um outro que o utiliza sob contexto, situação e tempo adequados. Seria como um jogo, em que as pessoas, ao performatizar relações de poder, já soubessem das regras e o jogassem de modo a cumprir certos rituais. Porém não é possível pensar a violência como inevitável - como em um jogo, é possível construir estratégias para lidar com regras violentas, temática que será aprofundada na parte dos resultados sobre estratégias de enfrentamento.

Ao afirmar que ela não é só física, ela também pode ser moral, percebe-se a congruência também com Minayo (2006): a violência é primeiramente associada à física, por ser a forma mais visível, a palpável e a que causa mais impactos nos sistemas sociais. No entanto P8 utiliza o termo não é só para construir seu conceito de violência, não negando a violência física e sim adicionando que existem outras violências que, talvez, possam não estar em voga. Esses outros tipos de violência (moral, psicológica) de que P8 trata são intercruzamentos entre ordens do discurso médico e do jurídico que aparecem na produção de saberes ditos por ela.

Outra via de explicação da violência é dada por P9: violência pra mim é você infringir as leis da sociedade. Assim como P8, P9 busca na lei a definição, atribuindo um caráter penal à violência e depois acrescenta que é ultrapassar os limites de respeito e se o limite foi ultrapassado, quer dizer, se você está fazendo o mal, isso já é uma forma de ser violento. Parece haver uma relação sinonímica entre leis da sociedade, limites de respeito e o mal pois todos os sintagmas são metas de processos materiais (infringir, ultrapassar e fazer, respectivamente). Portanto a violência seria fazer o mal, que significa passar certos limites que, por sua vez, são materializados nas leis da sociedade. P9, 
mulher branca cis lésbica, parece estabelecer uma relação causal entre um processo material com determinado atributo - fazer o mal - com o significado de violência. Não historiciza nem personaliza essa violência, em um esforço de definir de modo "neutro" a violência. Tal distanciamento também é buscado quando o assunto é família: mesmo se identificando para mim como lésbica, P9 afirmou que para a mãe ela é bissexual, por ser mais "fácil e aceitável". Fairclough (2003) aponta esse uso do discurso como constituinte da ação estratégica do enunciador, que faz dele instrumento para mediar a realidade.

Percebe-se, ademais, a fala interdiscursiva com aspectos das práticas jurídica e religiosa. Apesar de o ator ser a pessoa com quem se fala - no contexto da pesquisa o entrevistador - o uso de você é utilizado como metonímia da parte pelo todo. Quando P9 usa o pronome de tratamento, a intenção é falar de toda a sociedade e não de indivíduos específicos. Assim ela atribui a todos a responsabilidade por quase tudo (pessoas e os animais e o meio ambiente). Talvez por ter relatado no início da entrevista sobre seu nervosismo em participar da pesquisa, mesmo que eu buscasse explicitar o caráter informal e não avaliativo das perguntas, P9 tenha utilizado essa estratégia discursiva de generalizar ao máximo suas respostas - pelo menos no início de nossa conversa - a fim de que não sinta que "errou".

Outras falas se organizam em torno das pessoas vitimadas pela violência, como são as transcritas a seguir.

- "é uma violência interna também para a gente, e prisão mesmo, a gente tem esse medo o tempo inteiro de acontecer essas situações e isso acaba limitando a gente de não fazer as coisas, não deixando a gente ser nós mesmos" (P5)

- "é ser bombardeada por olhares agressores (...) não precisa nem tocar, nem falar precisa nada, só olhares (...) você tem que sair de casa meio que caçando rotas seguras para andar" (P4)

- "é aquilo que te impede de ir pra algum lugar, de fazer alguma coisa, basicamente é aquilo que te impede de ser o que é" (P2) 
- "acho que é todo tipo de ato ou ação, desde verbal, física ou, realmente, às vezes mesmo de uma maneira simbólica, às vezes invisível que coloca em uma situação de vulnerabilidade (...) de certa maneira cerceia a possibilidade de você ser, socialmente falando" (P7)

- "qualquer coisa que te limite (...) acho que uma brincadeira pode ser uma violência, se ela te limita não ser você naquele espaço (...), tudo que tira sua liberdade no espaço" (P6)

P5 conceitua a violência pelas duas perspectivas, a da vítima e a do agressor: utiliza-se de certa visão interna e individual para explicar sua percepção do que é violência. O participante narra a impossibilidade de "ser nós mesmos", de não poder aparecer - e quando há o impedimento de ser parte do coletivo que constitui o espaço do aparecimento, então também será impedido do direito a ter direitos (BUTLER, 2018).

No entanto, diferentemente de quando fala sobre quem agride, seu discurso pela via da vítima encontra consonância com as outras falas ao afirmar que violência é um constrangimento de algo presente no ambiente e não nomeado.

Tal constrangimento pode ser limitação (P5 e P6), cerceamento (P7), impedimento $(\mathrm{P} 2)$ ou ataque ( $\mathrm{P} 4)$. Pensemos essa sequência como gradativa, quase como um script, decorrente de um poder simbólico. Quando P5 metaforiza a violência como uma prisão, colocando-a no interno que resulta em limitação do ser ou quando P6 faz alusão a brincadeiras que limitam - portanto não fisicamente, mas simbolicamente - percebemos que não existe uma coação material que, efetivamente, limita o corpo de se movimentar (BOURDIEU, 1989). Existe, de fato, algo da ordem cultural e das relações sociais, que não deixa que o corpo performatize sua identidade, parando processos de subjetivação em determinado ponto. Além disso, é expressa aqui também a noção de que esse corpo é limitável, ou seja, tem algo que impede o corpo e o corpo é em si algo que pode ser impedido, devido, segundo Bourdieu (2002), às condições sociais de produção desse corpo e à hierarquização de características dele, em comparação aos dominantes - se a hegemonia estiver 
sendo exercida por outros corpos geralmente magros, quanto mais o corpo limitado se aproximar disso, menos limites serão impostos.

O processo material limitar possui menos força (talvez uma violência eufemizada?), pois pode significar algo estático, que define o fim ou o começo de algo, sendo que este algo, mesmo violento, é apassivado, podendo a vítima chegar a esse limite. O mesmo vale para cercear, uma vez que indica restrição, podendo mesmo ser sinônimo de limite. A determinação da violência, já dita simbólica, aparece com mais força do que o limite pelo processo material impedir. Sendo sinônimo de impossibilitar, proibir e obstruir (DICIONÁRIO, 2017), o ato de impedimento é algo mais ativo, da ação direta sobre o corpo violentado, mesmo sendo simbólico. Ao impedir, não se dá possibilidades de movimentação, ao contrário de limitar e cercear, que definem por onde movimentar. O poderio simbólico chega-se ao ápice quando a violência é definida como metáfora à guerra, pelo processo material bombardear. Chego a refletir que talvez não fosse mais simbólico pela força com que a violência é definida, porém, novamente, não há coação física - o bombardeio é de olhares.

Assim, o olhar não é apenas um simples poder universal e abstrato de subjetivação (...); é um poder simbólico cuja eficácia depende da posição relativa daquele que percebe e daquele que é percebido, e do grau em que os esquemas de percepção e de apreciação postos em ação são conhecidos e reconhecidos por aquele a quem se aplicam (BOURDIEU, 2002, p. 120),

muito semelhante às condições da performatividade propostos por Butler (2003) e Mingo e Moreno (2017), colaborando para a forçosa "naturalidade" das violências contra corpos dissidentes da norma.

Tais simbolismos de violência pertencem a um campo semântico transversalizado pela metaforização da guerra (prisão, agressores, rotas seguras). E quem está nessa guerra? Pode ser um eu que é constrangido a agir de determinada maneira, que a todo momento pergunta-se "Como devo agir?" ou "O que devo fazer agora?" (BUTLER, 2015a; GAGLIANONE, 2016). As respostas advêm de um contexto social em relação a um outro, também presente na guerra, porém invisível, inominável, que estabelece as regras e se 
certifica de sua reprodução. Pode ser 0 ethos coletivo, a cisheteronormatividade ou ainda ambos, interligados e complementares. De toda forma, estabelece-se um corpo-limite: corpo territorializado, que anda com cautela, caçando rotas, que entra em combate como alvo, pois é limitado, cerceado, impedido, bombardeado. Essa ordem discursiva geopolítica que transpassa o corpo-limite LGBT+ é regulado por ideologias hegemônicas altamente negativas em relação às suas ontologias, às suas existências, que, assim, são permeadas pela negação.

Neste tópico tratamos dos conceitos construídos pelas(os) participantes da pesquisa sobre violência. Ela está ligada fortemente a outros significantes como medo, agressão, preconceito, abuso sexual e travesti. Nota-se sua relação sinonímica não apenas com outros atos iterados mas também com a performatividade de um gênero específico. Isso leva-nos a perceber que a vida travesti é vida violentada: a partir do ponto em que o sujeito afirma-se na cena enunciativa como tal, as relações serão mediadas por práticas reconhecidas como violentas, até que haja intervenções de proteção da cidadania deste ser. Adentrando nas definições de violência pela comunidade LGBT+ universitária, identificou-se atravessamentos de diversas ordens de discursos para elaboração do saber sobre o tema: religioso, jurídico, estruturalista e biomédico. As(os) participantes utilizaram, portanto, de construções discursivas instituídas para construir outros, próprios, porém de maneira interdiscursiva. Nessas construções realizadas na cena enunciativa da entrevista, percebeu-se a repetição de sintagmas que aqui foram analisados como significantes de um corpo-limite, impedido de existir pelas violências. Ele existe em outro campo, o das práticas discursivas bélicas, em que precisa lutar, esconder-se, sendo abjeto da relação hegemônica estabelecida sobre ele. No próximo tópico discutiremos os relatos das(os) entrevistadas(os), a fim de analisar em profundidade como acontecem a materialização desses conceitos construídos até agora sobre violências. 


\subsection{Sobre cenas violentas}

Após conversar com as(os) entrevistadas(os) sobre o que é violência, pergunto se já vivenciaram ou presenciaram momentos violentos em seus cotidianos, seja em relação às identidades de gênero ou orientações sexuais. P7 relata sobre sua infância:

- "acho que a violência que mais marcou a mim foi a infância (...) com apelidos, com agressão física, não diretamente pela situação de gênero, mas indiretamente leva a isso" (P7)

A infância parece ser a primeira etapa da vida em que as experiências violentas se fazem presentes nos processos de subjetivação das pessoas LGBT+. Mesmo que não sejam sempre marcas físicas, as violências vivenciadas realizam $\circ$ processo material de marcar, de deixar uma determinada cicatriz em um corpo generificado, ainda que, a princípio, não seja a motivação principal para as violências. Essas marcas permanecem até a vida adulta, como P7 diz a seguir:

- "ela (minha trajetória) se passou justamente nessa autorrepressão do meu, que tem o processo da infância e que isso foi carregando muito pra minha vida adulta (...) a ilusão que eu tinha de uma realidade que eu me invisibilizava enquanto pessoa, então era certa repressão minha, que foi promovida também por conta da minha história de infância e adolescência" (P7)

Percebe-se que a performatividade de gênero é mediada não apenas pelas condições atuais de contexto, pelos atores participantes e pela execução ritualística do ato (MINGO; MORENO, 2017), mas também pela história pregressa do sujeito, que busca estratégias de enfrentamento (autorrepressão, invisibilização) para estar no presente. Essa introjeção de algo externo a que P7 se refere pode ser lida como a violência simbólica, em que a cultura hegemônica é assimilada pelos grupos que não possuem poder econômico, com o objetivo de perpetuar a dominação e aniquilar outros modos de ser (BOURDIEU, 1989). 
A violência simbólica se institui por intermédio da adesão que o dominado não pode deixar de conceder ao dominante (e, portanto, à dominação) quando ele não dispõe, para pensá-la e para se pensar, ou melhor, para pensar sua relação com ele, mais que de instrumentos de conhecimento que ambos têm em comum e que, não sendo mais que a forma incorporada da relação de dominação, fazem esta relação ser vista como natural (BOURDIEU, 2002, p. 47).

Um dos dispositivos utilizados para operar essa lógica é a escola, locus bastante citado pelas(os) participantes:

- "houve um caso que foi da professora, ela mesmo falar (depois de ter presenciado outros colegas chamando o entrevistado de bichinha) 'Cuidado! Não fica chamando porque ele pode depois virar um tipo maníaco' (...). Então assim foi uma tentativa de ajuda, é uma professora que tentou interferir, mas ela não tinha didática nenhuma" (P7)

- "na minha pré-adolescência, adolescência, eu ainda não tinha consciência da minha sexualidade, da minha orientação sexual, da minha condição enquanto homem gay e na escola acontecia muito tipo de violência que hoje é considerado bullying, apelidos, uma certa diferenciação das pessoas no tratamento, pelo fato de eu ser gay e até negro mesmo (...) não tinha muito interesse em ir à aula" (P1)

- "já sofri violência de abuso sexual, de abuso físico, de abuso psicológico, principalmente em escola (...) saí da escola pública justamente por isso, porque não aguentava mais o tanto que sofria na escola" (P6)

- "tenho violência psicológica, eu já sofri na escola porque as pessoas percebiam que eu olhava as meninas e começavam a me cutucar indiretamente, às vezes até diretamente, me faziam sentir mal, me sentir inferior, me colocarem pra baixo, já sofri bullying (...) as pessoas cochichavam, dava pra notar que desconfiavam e ficavam conversando e falando mal pelas costas" (P9)

- "teve uma hora que fui sentar na mesa com minhas colegas, igual sempre fazia eles saíram, todos saíram da mesa" (P9) 
- "tinha um menino, ele sofreu também (...) eu vi um deles falando, se referindo ao menino 'Ah, vira homem!', tipo simulando um chute” (P9)

A caracterização das vivências reconhecidas como violentas na escola é permeada pela multiplicidade de processos: materiais (sofrer, interferir, sair, cochichar), mentais (perceber, sentir, desconfiar), relacionais (ser, ter), verbais (referir, chamar, falar) e existenciais (haver). Percebe-se a multiplicidade dos processos envolvendo experiências violentas, corroborando com Minayo (2016) sobre a pluralidade do conceito de violência. A prática sociodiscursiva escolar evidenciada pelos relatos é normativa, em que o corpo desviante de um ideal de criança ou adolescente é chamado de maníaco, é alvo de violências constantes e relegado ou à solidão, motivado pela individualidade possessiva e autossuficiência das outras pessoas que o cerca, ou ao destaque pejorativo, em que o corpo desviante é tomado pelo discurso do outro para servir de exemplo a ser evitado por outros colegas de escola.

Essas vivências escolares de cunho violento são conhecidas como bullying. Segundo Souza, Silva e Santos (2015), bullying é a ação repetida de constrangimentos, assédios, ameaças e agressões entre sujeitos percebidos como desiguais em uma relação de poder e reforçada por testemunhas. Nesta mesma pesquisa, concluíram que $32 \%$ de escolares são alvo de bullying, chegando a $58 \%$ entra adolescentes LGBT+ e que a homofobia é o segundo motivo mais frequente de violência na escola entre os meninos, sendo a terceira no geral. Isso corrobora com a presença maior de relatos de bullying entre os participantes do que entre as entrevistadas, já que P6, P1 e P7 trouxeram tais episódios à conversa. Segundo Louro (1997), a escola é instituição que marca as diferenças: separou (e ainda separa) o rico do pobre, o branco do negro, o intelectual do operário, o menino da menina. Ao separar, a escola produz sujeitos e sutilmente força a naturalização, servindo, também, como um dos dispositivos daquele ethos anacrônico. A pessoa ou a ideia LGBT+ é negada no contexto escolar, sob o medo de que as crianças e adolescentes conheçam-na e se interessem pelo "desvio", portanto a

negação dos/as homossexuais no espaço legitimado da sala de aula acaba por confiná-los às "gozações" e aos 
"insultos" dos recreios e dos jogos, fazendo com que, deste modo, jovens gays e lésbicas só possam se reconhecer como desviantes, indesejados ou ridículos" (LOURO, 1997, p. 68).

P9 traz exemplos dessa cena em seu relato. Nessa mesma linha, P2 resume o bullying e coloca o uso de tecnologias para reforçar a discussão:

- "bullying com o gay é sempre o mesmo, é a chacota, é a agressão física, a não aceitação, é a humilhação (...) o bullying é o mesmo, a diferença que hoje você tem uma coisa mais perversa que é o smartphone que pode gravar isso" (P2)

Em todos os excertos existe a lógica de se usar características consideradas hierárquicas para dominar o outro, então o modo de olhar para determinados corpos, o comportamento, enfim, a performance não heteronormativizada é utilizada para o bullying, somada, como no caso de $\mathrm{P} 1$, à negritude. Assim, os sulcos por onde as relações de poder fluem se interseccionam para fortificar as violências na escola: ser percebido como LGBT+, como negra, como pobre são cruzamentos perigosos para os corpos e limitam direitos como à vida e à educação. P1 e P6 expressaram esse desinteresse em ir à escola por conta do bullying e, apesar de tal evento não ter impedido de ambos chegarem ao ensino superior, essa não é a tônica, principalmente para pessoas trans (SOUZA; BERNARDO, 2014). O abandono escolar é uma fase do ciclo de exclusão em que pessoas LGBT+ são inseridas, que começa na austeridade da escola elou da família e provocam impactos quando chegam ao mundo do trabalho, principalmente de pessoas trans, levando à prostituição sem haver necessariamente o desejo de seguir essa profissão, por exemplo (TERRA, 2011; MOREIRA, 2012; MORAIS; SILVEIRA JUNIOR; LUCKOW, 2015; ALMEIDA, 2016).

Faz-se necessário, com o auxílio de Vartabedian (2017), ponderar que o trabalho sexual pode ser visto também como espaço importante de garantias de moradia e alimentação e para empoderamento, por haver a necessidade de estar/sentir-se bela para conseguir trabalhar, não constituindo (pelo menos não 
primordialmente) como última saída para todas as pessoas trans, de modo especial para performatividades transfemininas.

Atualmente, na contramão das necessidades sociais por mais direitos, 0 programa "Escola Sem Partido" busca interferir na produção de políticas públicas de educação a fim de forçar uma pauta neoliberal da heteronormatividade, já que busca expulsar o caráter político da escola e substituir por outro de cunho econômico e conteudista (MACEDO, 2017). Quando as pessoas relatam as vivências violentas dentro de um dispositivo pretensamente garantidor de direitos como é a escola, não é cabível que exista um modo de ensino e aprendizagem que ignore tais circunstâncias para focar na "neutralidade" (que já nasceu morta) e assim anular ontologias de crianças e adolescentes. O programa "Escola Sem Partido" reforça o bullying, produz mortes ontológicas e contribui para o genocídio da comunidade LGBT+.

Outro momento de violência durante a infância, mas que aconteceu fora da escola, é relatado por P7:

- "desde a infância eu tive uma vida sexual mais iniciada de uma maneira abusiva, hoje eu falo que é abusiva, às vezes eu achava que não era porque eram gente maiores (de idade) que aproveitavam do fato de ser sempre caçoado na rua (...) da pessoa me coibir, de me impor um ato sexual com ela senão ela ia contar pra fulano" (P7)

Neste excerto é estabelecido um processo relacional (ter) entre P7 e vida sexual, modalizado pelo abuso, não à época do ocorrido, mas no momento presente, pois $\mathrm{P} 7$ entende que foram abusivas suas primeiras experiências sexuais ao revisitá-las e relê-las. Portanto o reconhecimento da violência só ocorre se houver, primeiramente, o conhecimento da experiência (CANSECO, 2015). Ao não conhecer o abuso como tal, $P 7$ perde a agência em relação ao fato e não há quaisquer intervenções sobre a violência, já que não é reconhecida. Isso leva à cristalização da performance violenta, uma vez que a percepção é de que as coisas são assim mesmo, ou só podem ser assim, pois de outra forma vai ser pior, por exemplo se a orientação sexual de $\mathrm{P} 7$ fosse publicizada. Essa ideia de superioridade em relação à criança e à pessoa 
adolescente por conta da ciência de um fato que, em tese, deveria ser segredo, contribui para a perpetuação do abuso e impede o desenvolvimento dela enquanto ser humano de direitos (NATARELLI et al., 2015). Essa prática do segredo em relação à sexualidade está ligada a práticas discursivas religiosas, cujos valores tangenciam o silêncio, o secreto e a castidade.

Continuando na narrativa de $\mathrm{P} 7$, chegamos às amizades e às ordens do discurso de afeto:

- "segregação também, assim, você, por exemplo, ter amigos, aí de repente quando eles sabem de sua sexualidade, eles param de... não tem a mesma forma" (P7)

O afastamento de amigos ou a mudança na forma é descrito por P7 primeiro como processo relacional (ter), depois processo mental (saber), seguido do material (parar de) e termina com o mesmo relacional, porém negativa. Então é eu ter, eles saberem, eles pararem, eu não ter. Essa mudança na relação pode ser a fuga do ethos violento, que escolhe seus alvos para, ao excluírem, poder permanecer na atualidade, mesmo com atitudes, crenças e valores de épocas passadas. Os amigos buscam, então, se afastar da esfera não-heteronormativa para que não sejam resvalados pelas violências. Percebe-se que não é necessário um processo material ou verbal de P7 para que ocorra o afastamento, ou seja, ele não precisou contar, dizer ou reunir com amigos, bastou que eles soubessem (de outra fonte, talvez) para pararem. Esse relatar a si mesmo pelo outro é explicado por P2:

- "você não se descobre gay na maioria das vezes; na maioria das vezes as pessoas descobrem pra você, é quando começam a te apontar 'Ah viadinho, ah esse menino é viadinho, é bichinha' (...) você é avisado que é gay, alguém te avisa que você é gay" (P2)

Neste excerto P2 relata uma situação em que a identidade LGBT+ é definida a partir de processos materiais cujos atores não são corpos que performatizam tais identidades, mas sim outros, possivelmente com identidades heteronormativas, que descobrem, apontam e avisam esse corpo LGBT+. 
Assim, nessa cena enunciativa, a performance a ser desempenhada é definida por quem se percebe com poder para tal, como P8 disse anteriormente - quem é o viadinho, a bichinha, quais atos performativos serão próprias desses nomes e quais não serão e principalmente qual vai ser a resposta de outros atores frente a esse corpo apontado, avisado e descoberto. Essa violência do relato do outro em si, violência ética (BUTLER, 2015) é a cena de interpelação à qual pessoas LGBT+ são imbuídas a assumir identidades percebidas e obrigadas a possuir-se de si - porém esse "eu" é construído por um outro autossuficiente, que, certo de sua existência, percebe-se capaz de nomear os sujeitos que encontra. $O$ ethos violento, como conjunto de costumes e hábitos fundamentadores de um grupo ou de uma época que compõem valores sociais e éticos (CHALUB, 2015), possibilita tal relação de apontamentos ontológicos ao buscar reproduzir seu anacronismo nos corpos em cena.

Esse ato de desfazer a ontologia e existência do corpo que foge à matriz é confirmado por outro estudo com mulheres lésbicas (TOLEDO; TEIXEIRA FILHO, 2013). Conhecido como "assumir-se" ou "sair do armário", esse ato performativo é violento no sentido de impor mais uma performatividade a um corpo incategorizável, inteligível. Isto porque desde o nascimento nos são atribuídas performances, inclusive de gênero, ou seja, somos formados ontologicamente também pela violência (BUTLER, 2015b). E P7 continua sobre um efeito dessa imposição:

- "tinha vergonha de me assumir" (P7)

Esse processo relacional (ter) entre P7 (portador) e vergonha (atributo) se refere a outro processo, porém mental (assumir). $O$ assumir-se, assim como "sair do armário" é um ato político, porém permeado de individualidades, pois é (re)construído a cada encontro com o outro, considerado importante em alguma esfera da vida (pessoal, institucional e/ou econômica) (SEDGWICK, 2007). Então a pessoa LGBT+ nunca sai completamente desse armário, pois a cada nova amizade, novo emprego ou mesmo quando revisita relações do passado, o assumir-se ou ocultar-se se refaz como necessário (LOSERT et al., 2008; SOUZA, 2012). No caso de P7, a vergonha é a justificativa para 
reconstruir o armário. Portanto, assumir-se não acaba com a relação de ninguém com o armário (SEDGWICK, 2007). Além disso, a ideia de assumir-se provém de uma lógica heteronormativa, já que o pressuposto hegemonicamente instituído é se relacionar com o sexo e/ou gênero oposto ao designado. Assumir-se, assim, é revelar esse "segredo", quebrar essa linearidade e bancar esse lugar de desregulado, deslocando o insulto para sua significação afirmativa (BUTLER, 2003; MONTEIRO, 2009). Talvez o processo "assumir-se", sinônimo de tomar para si, apropriar-se, tomar aparência de, exibir (DICIONÁRIO, 2017) não seja o mais condizente com as demandas da comunidade LGBT+, já que sua noção é algo externo (apontado, avisado) que é tomado para si, assumido. Tenho percebido, dentro das ações coletivas de movimentos sociais, o uso dos verbos entender-se e compreender, que podem ser menos contraditórios e heteronormativizantes que assumir-se, uma vez que abre possibilidades de entendimento para algo construído de maneira relacional.

As interseccionalidades ligadas às violências contra pessoas LGBT+ foram marcantes na maioria das entrevistas e os excertos a seguir exemplificam isso:

- "(quando adulto) acho que a violência que eu mais senti foi dentro do meio gay (...) envolve a questão de gênero mais outras questões de identidade racial, estética (...) a violência maior é tratamento interno, dentro do próprio movimento por conta de certos padrões e ações, certa padronização de que... ou enquadramento da identidade que às vezes dificulta qual a ideia de gay aqui" (P7)

- "a violência que eu senti mais impactante direto, dentro da minha trajetória aqui (em Belo Horizonte) já depois, de 20 anos pra cá, ela foi mais impactada pela questão racial do que gay (...) porque você é gay e você é negro, aí junta um, aí vira um problema mais intenso, social, porque você tem que lidar socialmente minha orientação sexual com minha negritude (...) talvez a questão gay porque também é uma coisa que eu não comento, mas a questão da negritude é mais estética, ela é mais falada, mais visível no meu caso" (P7) 
O que P7 traz são as diferenças intragrupais das quais Crenshaw (2004) relata na sua teoria interseccional, cujos processos são iniciados por aqueles de origem mental (sentir), seguidos de relacionais ligados a identificadores (ser negro, ser gay) que culminam em processos de natureza material (dificultar, lidar), por meio da circunstância de modo e comparativa (pela questão racial do que gay). Percebe-se que, no interior de Minas Gerais, P7 sofria mais violências em função de sua identidade gay, ao passo que na capital o alvo ethoico se inverte e passa a ser sua identidade negra. Silverio Junior (2013) aponta que, em cidades do interior, a reprodução de preconceitos de gênero e orientação sexual ocorre mais facilmente do que no espaço anônimo das metrópoles por conta da delimitação física e geográfica. Então a vigilância dos corpos acontece antes pela performatividade. No entanto, ao se ampliar para a cidade, não é possível vigiar mais corpos dissonantes à heteronorma da mesma maneira interiorana, pois isso envolve tempo para perceber posturas, linguagens e símbolos, mas a cor da pele, o cabelo e outros traços corporais são identificáveis rapidamente, ao tempo da metrópole, e se tornam alvos do fluxo racista. Percebe-se, então, que a relação hegemônica dos corpos LGBT+ é territorializada, em que a mudança de domínio geográfico resulta na preponderância de um ou outro fluxo de poder. Logo a hegemonia é parcial e temporária, mudando à medida que aspectos sociais, culturais vão modificando-se (FAIRCLOUGH, 2001).

Outras participantes trazem perspectivas complementares sobre a relação interior-metrópole:

- "violências físicas são muito intensas dentro das cidades grandes por conta do fluxo de pessoas" (P7)

- "é muito diferente daqui de $\mathrm{BH}$, as pessoas aceitam muito mais do que lá em Santa Luzia (...) (lá) ninguém aceita, ninguém entende, ninguém quer aceitar, ninguém quer entender" (P4)

- "aqui na cidade grande a gente já percebe uma violência mais agressiva, uma violência mais física, eu tenho essa percepção assim. Comigo nunca aconteceu, mas eu ouço relatos de muita gente contando (...) é uma violência bem mais física e lá (no interior) é uma violência 
mais psicológica, agride da mesma forma, mas é menos visível do que a violência física daqui" (P6)

- "município (de origem) muito machista, então a violência vem por volta de brincadeiras, é bullying, essas coisas que a gente sofre ne, o viado daqui" (P6)

Observa-se a construção argumentativa gradativa de intensidade - na cidade é muito intenso, é muito diferente, é mais agressiva, é muito machista. Se, em cidades do interior dos estados, são atribuídos às violências marcadores de intensidade, é possível entender que esses são mais uma faceta do poder por onde fluem as energias de diferenciação. Soma-se a isso o corpo gordo e a pele escura e temos um grupo atravessado pelas relações violentas de poder. O documentário "Todo mundo vai saber", de Eduardo Bittar (2017) é um importante material que visa mergulhar "na história de homens homossexuais que nasceram e cresceram em Formosa, uma cidade do interior de Goiás". Naquele, os narradores de suas próprias vidas relatam que uma pessoa LGBT+ na cidade interiorana é "ponto turístico", pois a população da cidade começa a referenciá-la, ligando com outros familiares: "Você viu o Tiago, filho de fulana, sobrinho de cicrano?". Por outro lado, na capital a LGBT+ se dilui na multidão e não carece de destaque, ou seja, "é só mais um viado" (BITTAR, 2017), corroborando com a ideia da territorialização das violências contra pessoas LGBT+. E esse fluxo comparativo interior-cidade se conforma também como caminho migratório, por vezes de fuga, para poder viver, ter momentos de lazer, socializar, etc. (KUHAR; SVAB, 2014). Um dos participantes pondera, ao explicar o motivo por manter sentimentos positivados pela cidade do interior de origem, que as pessoas que lá permanecem não possuem o mesmo acesso a conhecimentos e dispositivos de afirmação de identidades, permanecendo constrangidas em performances heteronormativas. Como diz Ellen Oleria em sua composição Não Lugar: Quem vai/ Vai porque precisa/ Quem fica/ Fica porque não pôde ir/ Quem fica é quem sofre".

Os relatos também produzem significados negativos, por meio de processos mentais desiderativos associados a atores indefinidos: ninguém aceita, ninguém entende, ninguém quer aceitar, ninguém quer entender. Essa 
construção epanafórica indica uma situação recorrente no cotidiano de P4, em que o outro é insensível e ignorante por opção. Esse outro novamente não tem nome, é ninguém: parece que a estratégia ethoica de se tornar "normal", "invisível" e "natural" funciona fortemente nesse excerto pois se dissolve na multidão de ninguéns. A participante que traz esse ponto para a entrevista é a mesma que busca rotas para sair, levando-nos a pensar que a fuga é de todos, já que ninguém é passível de confiança, pois não entendem, não aceitam, não querem entender, não querem aceitar. Esse modo de vida é constrangido por diversas práticas sociodiscursivas que conformam a vida em cidades do interior e em cidades metropolitanas - religioso, escolar, jurídico, etc. Tal situação pode ser exemplificada pela experiência que $\mathrm{P} 1$ traz:

- "no meio daquele grupo, daquela multidão, um homem chegou pra ela e queria beijar ela a força e ela falou que não e ele falou que ela era uma sapatona preta, que ela fedia" (P1)

Relatando um evento carnavalesco, P1 utiliza da verbiagem (ela falou que) para designar a discriminação contra mulheres lésbicas negras: "sapatona preta" ligada a um processo material (ela fedia). Vamos detalhar um pouco cada sintagma para tentar compreender melhor as violências experienciadas por esse grupo.

"Sapatona" é um termo para nomear lésbicas, geralmente utilizado em contextos de insulto ou de menosprezo, ou ainda ressignificado pelas mulheres para se definirem politicamente. Sua origem está ligada às produções musicais de temática carnaval de Chacrinha, artista brasileiro da década de 1980 e ligase a um imaginário performático de mulheres extremamente masculinizadas, o qual mulheres "se passam" por homens, principalmente à noite (LACOMBE, 2007). "Preta" está ligado a cor da pele escura e parece ter sido utilizada inicialmente para definir pessoas escravizadas por europeus nos continentes africano e americano (BLACK PAGES BRAZIL, 2017), sendo contemporaneamente ressignificado para afirmação de uma identidade política, deslocando $O$ insulto, apropriando-se do xingamento para, semântica e ideologicamente, rebelar-se ao instituído (SEVILLA; SEFFNER, 2013). 
No entanto, da mesma forma que "sapatona", a palavra preta não é aceita consensualmente no intragrupo. "Feder" é exalar mau cheiro ou odor impuro. Ao atribuir tais nomeações à mulher, o agressor performatiza a violência como vingança por não ter alcançado seu objetivo. Assim busca inferiorizar seu alvo em função de sua orientação sexual percebida (já que não houve afirmação de nenhuma identidade durante a cena) e da cor de sua pele, inclusive associando-a a cheiros que seriam característicos. Percebe-se, então, os sulcos (CRENSHAW, 2004) por onde o poder passa para cruzar esse corpo de mulher negra lésbica. Tais sulcos podem também auxiliar na compreensão de como algumas pessoas participantes da pesquisa não relataram casos de violência consigo mesmas:

- "A violência física, pelo fato de ser negro gay, eu nunca sofri. No cotidiano eu já vi muito, mas assim especificamente não vivenciei" (P1)

- "até então eu nunca sofri nada por ser quem eu sou e por ser da cor que eu tenho, mas eu tenho certeza absoluta que sim, todo mundo meio que sofre por ser negro e por ter essa opção Agora ainda mais porque junta feminista, negra e lésbica, acho que é um trio que chama práticas de ter preconceito" (P4)

Mesmo se incluindo em um grupo que chama práticas de ter preconceito, $\mathrm{P} 4 \mathrm{e}$ $\mathrm{P} 1$ relataram não ter passado por nenhuma situação dessa natureza. É possível que outras características como renda, escolaridade ou classe possam diminuir a força das assimetrias das relações de poder, das práticas e atos de violência, não chegando a serem perceptíveis as violências interseccionais de negro gay ou lésbica negra feminista.

Resumindo:

- "quando você fala de $L G B T$, você pode falar de questão racial e você pode falar de misoginia, é tudo muito próximo, tudo se mistura porque está tudo no mesmo patamar que é um lugar do patriarcado que fica te oprimindo" (P2) 
Ou seja, as formas violentas contra pessoas LGBT+ negras elou mulheres estão atravessadas por uma ordem hegemônica e ideológica, originadas, segundo P2, de patriarcado. Burckhart (2017, p. 207) o define como "sistema político-cultural de opressão que se difunde por meio da dominação simbólica dos detentores do padrão de poder generificado (homens) sobre mulheres e demais seres subjugados". Butler (2003) afirma que a produção de corpos sexuados binários é uma das sustentações do patriarcado, pois, a partir dessa divisão assentada no biologicismo, é possível designar corpos que repetem atos que reproduzem essa hegemonia.

É necessário alertar que, mesmo sendo possível analisar separadamente, as relações de poder estabelecidas assimetricamente em função de raça, gênero e orientação sexual não são variáveis independentes, mas sim imbricadas, alimentando umas às outras para manutenção de ideologias (BRAH, 2006), como P7 e P8 sinalizam:

- "minha amiga que é lésbica, o cara zuou alguma coisa e ela, acho que foi lesbofóbico, só que ela reagiu: pegou uma garrafa assim aí ele foi e saiu (...) ela sofre mais do que eu, que sou um gay, mas sou cis, eu sigo uma estética mais heteronormativa, então talvez eu me assegure" (P7)

- "estar andando na rua com uma namorada ou de mãos dadas e por exemplo cantadas dos caras, eles falam que querem entrar no meio, que isso é falta de piroca, violências do tipo ouvir pessoas como um vizinho meu falando que o fato de ser lésbica é que faltou um pinto, que eu devia transar com ele para saber como é que é um homem de verdade na minha vida. Violência física não chegou a ocorrer, mas essa violência que é quase que física ne, porque a gente começa a sentir medo nos lugares que a gente vai, aí isso eu sofri várias vezes, nas ruas de BH mesmo" (P8)

Outra interseccionalidade das vivências violentas da comunidade LGBT+ universitária é apontada por P7 ao definir sua própria performatividade masculinidade homem cis gay na cena cotidiana heteronormatizada, 
contrastando com outra performatividade feminina, mulher lésbica, como P8, corpo entendido como menos seguro, sofredor intenso (sofre mais). Tal entendimento se materializada nas experiências relacionadas a duas práticas de subjugação do sujeito mulher: fetichização das lésbicas e estupro corretivo. O fetiche heteronormatizado em que o homem deve estar "no meio" de uma relação sexual lésbica é marcador de tolerância, uma vez que é aceitável desde que o homem esteja presente, sendo servido por elas; já o estupro corretivo (faltou um pinto e transar com ele para saber como é que é um homem de verdade são discursos dessa ordem) é prática que visa "voltar ao normal" algo que está "fora da ordem", por exemplo, a lesbiandade (MARCELINO, 2013). Como pontua $P 8$, mesmo não sendo física, essas violências estão no corpo e tem-no como alvo e instrumento, executando-as fisicamente. Assim, as diferenças intragrupais parecem estar fortemente ligadas à estética-aparência, ao que é percebido na superfície do corpo. Tal exteriorização da diferença alcança o âmbito simbólico:

- "acho que a violência que tá é simbólica, de eu sempre ter medo, medo de sair na rua, ainda tenho muito medo de andar de mão dada com um cara que eu namoro, que eu fico, eu ando, mas sempre pensando, é muito isso, é um medo que tá promovido simbolicamente" (P7)

- "aí a minha violência é mais nisso assim, de mais interna assim, psicológica muitas vezes, que envolve o medo, que é promovido socialmente, mas que eu construo psicologicamente" (P7)

Observa-se que $\mathrm{P} 7$ relativiza sua performance por uma promoção do medo que acontece através de atos simbólicos entendidos coletivamente e internalizados, ou seja, constrangem-no a entrar no ato performativo, cujas regras são socialmente ensinadas pelo medo. Essa construção subjetiva da pessoa LGBT+ segue uma norma-matriz, baseada em um ideal regulatório ethoico, limitador da aparência ou do formato do corpo (SALIH, 2012). Assim, P7 relata que nunca está livre para ser o que quer - na verdade ele existe a partir de opções restritas da cena enunciativa/interpelação em que se encontra, iterando-as e com pouca margem de manobra para inovar ou para provocar fissuras. 
Assim, essa regulação da performance é repleta de constrangimentos que não são citados no excerto, mas facilmente inteligíveis se considerarmos dados sobre a violência contra pessoas LGBT+: medo de ser agredido, de ser assassinado, de não ter apoio institucional em assunto de segurança pública, assim como relatam $\mathrm{P} 7$ e P8:

- "eles estavam lá, tinha um grupo na outra mesa, numa pizzaria, aí eles foram e começaram a bater boca e depois foi agredido, segurança não fez nada (...) eu sei que eles foram na delegacia (...) segundo o relato, o pessoal, o tempo todo, ficou duvidando, sempre aquela dúvida, a suspeição (...) porque a piada da galera é questionando porque ali não tinha tantos gays e agora tá aparecendo" (P7)

- "essa polícia despreparada, principalmente, é mais uma opressão que a gente vai sofrer" (P8)

P7 traz um atributo recorrente às pessoas LGBT+, que pertence ao campo semântico da dúvida, da suspeição. Quando há denúncia por uma pessoa não heterossexual, duvida-se de quem é a vítima ou quando um homem gay vai doar sangue, duvida-se de sua integridade. Tornar uma pessoa LGBT+ suspeita é uma estratégia eficaz de evitar conflitos internos do ethos, pois a coloca em uma posição deslegitimável, desconsiderável, retirando dela qualquer atributo que mereça atenção. Assim sua performatividade, senão for da ordem hegemônica, é anulada. Se não elimina esse corpo da cena, pelo menos fica reservado à margem. Mesmo com restrições, algumas movimentações sociais buscam criar outros modos de ser, como a Ação Direta de Inconstitucionalidade n. 5543 no Supremo Tribunal Federal que questiona a inaptidão temporária para indivíduos do sexo masculino que tiveram relações sexuais com outros indivíduos do mesmo sexo realizarem doação sanguínea nos 12 (doze) meses subsequentes a tal prática (BRASIL, 2016). Atualmente o processo está sob pedido de vista antecipada dos autos, portanto não decidido pelas turmas do Tribunal.

Mello, Avelar e Brito (2014, p. 318) abordam as políticas públicas de segurança para a comunidade LGBT+ pelo paradoxo: "Nunca se teve tanto, e o que há é 
praticamente nada". Mesmo com diversas iniciativas acerca da violência específica contra pessoas LGBT+ como a inclusão do campo específico em boletins de ocorrência e delegacias especializadas, o que persiste é o culturalmente arraigado: culpabilização das vítimas, ocultamento do preconceito na motivação e a constante necessidade de superar o paradoxo da polícia despreparada ou do segurança que ameaça.

A suspeição volta à cena com $P 8$ :

- "tudo sempre soava como brincadeira, como essa sociedade machista, sexista e misógina faz ne, nossa voz nunca vai prevalecer, ela é sempre reclamação, é mimimi, é exagero, nunca é realmente, efetivamente um preconceito" (P8).

É exemplificado no excerto anterior atributos iterados e citacionalizados à voz LGBT+: sempre reclamação, mimimi, exagero. Esses atos que buscam diminuir a força e o volume dessa voz acontece nos mais variados contextos e práticas sociais, perpetrados por agressores que invisibilizam sentimentos e afetos do outro, tratando-os apenas na ordem do comportamental e não também como algo (re)produzido socialmente.

Outro dispositivo marcante nas entrevistas foi a família, que aparece nos relatos de violência desempenhando diversas performances, entre eles o de agressora.

- "(minha mãe) por pegar uma mensagem de cunho sexual com outro cara, ela não teve essa reação tranquila, ela teve uma reação pior, de nojo" (P7)

- "minha mãe começou a me olhar de um jeito estranho, minha vó também começou a olhar de um jeito estranho" (P4)

- "(antes da transição) ser ameaçada de morte várias vezes por pais de meninas com que me relacionava" (P5)

Tais relatos se referem a reações após a pessoa LGBT+ ter realizado algum processo material ou verbal de ordem não heteronormativa: P7 conversava 
com outro homem, P4 se identificou como lésbica para a família e P5 se relacionava com outras mulheres em um tempo anterior à transição. Palavras como nojo, estranho e morte são atributos e identificadores dessas reações e evocam formas de punição ao não retorno do investimento realizado pelas famílias para a adequação entre performance de gênero, sexo e orientação sexual linearmente heteronormatizadas (TOLEDO; TEIXEIRA FILHO, 2013) - o objetivo, portanto, é retomar o controle pela violência já que outros dispositivos como controle e vigilância não funcionaram (ARENDT, 2004). Baseia-se, portanto, em um ethos temporalizado por Toledo e Teixeira Filho (2013), no século XIX, em que a heterossexualidade se torna categoria designável no nascimento, naturalizando-a, e P8 pontua isso de forma contundente:

- "as pessoas heterossexuais, elas acham que elas são as normais, que a anormal é você e que você tem que respeitar isso, a opinião dela, a opinião dela vai sobrepor à sua dignidade" (P8)

Todas essas falas se remetem ao momento de quebra das expectativas da parentalidade, porém é um dos momentos mais marcantes para a comunidade LGBT+ pois "quando os segredos são revelados, temos menos a esconder e podemos ser mais espontâneos e mais vulneráveis" (MASON, 2002). E essa vulnerabilidade é provocada inclusive por piadas, de acordo com os excertos a seguir:

- "quando a pessoa por exemplo fazia comentários jocosos sobre a sua orientação sexual, te expõe de alguma forma, faz algum tipo de comentário, como já aconteceu comigo e isso pra mim foi uma violência (...) como eles são muito conservadores (no ambiente de trabalho), eles têm muito o hábito de fazer piadas entre eles, jocosas em relação a sexualidade. Então isso de certa forma acaba me incomodando" (P1)

- 'ela perguntou 'Ah, você é gay, você é hétero?', aí eu falei 'Não, sou bi', aí ela 'Biscate ne!?'” (P5)

De acordo com Possenti (2005, p. 37) "as piadas só podem ocorrer num solo fértil de problemas (...), solos cultivados durante séculos de disputas e de 
preconceitos". O mesmo autor continua explicando que, além deste solo, é preciso interlocutores dotados de inteligibilidade para o discurso humorado e de regras que expliquem por que determinado enunciado ocorre em certos contextos e não em outros. Tal cena discursiva da piada é muito semelhante às condições de performatividade (BUTLER, 2003; MINGO; MORENO, 2017), indicando que a piada contra pessoas LGBT+ também é performance e acontece no trabalho, segundo $\mathrm{P} 1$, pela relação explicativa entre "eles são muito conservadores" e "eles têm muito o hábito de fazer piadas entre eles, jocosas em relação à sexualidade".

A iterabilidade e citacionalidade desta prática discursiva conservadora, certamente hegemônica no local de trabalho - uma vez que P1 generaliza os locutores da piada por "eles", indicando muitos ou todos os outros - ocorrem pelo discurso da piada, que modifica e ressignifica para criticar, como aconteceu na experiência trazida por P5. Ao estabelecer relação sinonímica entre "bi" e "biscate", a interlocutora ressignifica a abreviação: bissexual seria, então, uma pessoa que se relaciona com qualquer um, "fácil", de vida "promíscua". A ressignificação por meio do gênero piada produz "questionamento e a crítica às práticas e costumes sérios e oficiais da sociedade, das instituições, etc. e assim conseguir virar isto tudo do avesso, como um discurso que pode provocar reflexões" (GRUDA, 2011, p. 757), porém, e por ser performatizado, é hábil instrumento para provocar o oposto assujeitamento, iteração das normas, valores e princípios das estruturas socioculturais, assentar tudo com gesso e cimento, evitando reflexões.

As cenas de violências de gênero e/ou orientação sexual são tão múltiplas quanto as identidades da comunidade LGBT+. E elas começam na infância, pela imposição de gênero e pelo constrangimento constante sobre o corpo, passando pelo bullying na escola e reverberando em cada espaço que a criança performatiza.

Em suma, mesmo que sejam iteradas essas violências no início da vida, elas modificam-se dependendo do local onde o corpo habita: cidade do interior ou capital. Segundo os relatos das(os) participantes, as violências contra LGBT+ 
são territorializada, ou seja, mudam-se os atos e os alvos dependendo do tamanho da cidade. Além dessa interseccionalidade geográfica, as percepções imediatas sobre o corpo negro aparecem como marcadores de diferenças intragrupais, uma vez que a orientação sexual pode não ser tão explícita quanto à negritude. Tais diferenças, fortemente transversalizadas por uma estética hegemônica, são materializadas por meio de piadas e da suspeição, em que as relações com pessoas LGBT+ são, de todo modo, estigmatizadas. $A$ importância de compreender as interseccionalidades dentro da comunidade LGBT+ reside na compreensão de que políticas públicas para grupos minoritários não podem contentar-se com uma característica para construir planos e estratégias de intervenção, ou seja, a questão que se coloca é

os serviços de saúde [estão] preparados para atender a uma jovem-negra-pobre-travesti, que geralmente não tem lugar nos programas e ações formulados pelos governos para jovens/negras/pobres/LGBT, inclusive no âmbito das políticas de saúde?" (MELLO; GONÇALVES, 2010, p. 169).

$\mathrm{Na}$ base disso está a ideologia patriarcal que constrange a performance e impõe anacronismos violentos. Moura e Oliveira (2016) apontam que a discriminação acontece justamente por esse confronto entre práticas discursivas de ordem LGBT+ e família, locus do patriarcado, e sua negação ou transposição em gêneros como a piada são instrumentos de luta ideológica. No próximo tópico abordaremos violências contra corpos trans, devido às suas especificidades.

\subsection{Sobre violências contra pessoas trans}

Devido às especificidades encontradas nas entrevistas e a necessidade política de proporcionar destaque às vivências trans, essa parte da dissertação analisará as violências sofridas por esse grupo, principalmente, pela fala do P5: 
- "quando a gente fala de violência contra LGBT, é muito diferente a pauta $T$ do resto da sigla" (P5)

De acordo com as entrevistas, percebemos que as experiências violentas de pessoas trans estavam relacionadas com sentidos humanos. Talvez pela violência ser construída na cenas de interpelação, ela só pode acontecer pela relação entre corpo, política e cultura, principalmente pela visão e pelo tato. $O$ olhar, relacionado à visão, foi o primeiro deles, presentes nos excertos a seguir:

- "violências do dia a dia sabe, o olhar na rua, opressão social que no caso meu namorado vive e eu sempre to com ele, às vezes sinto essa opressão de alguma forma (...) às vezes eu to com (meu namorado trans) e aí eu sinto o olhar pra ele sabe, tipo 'Como assim uma pessoa transexual?' e aí eu vejo muito esse olhar de opressão pra ele" (P8)

- "a gente é invisibilizado o tempo inteiro, as pessoas não sabem da nossa existência, principalmente dos homens trans e se elas não sabem, como elas vão respeitar?" (P5)

Processos mentais como sentir, ver (observar), invisibilizar - no sentido conotativo de tornar invisível, portanto de ordem perceptiva - e saber são destaque nas experiências violentas que utilizam o olhar contra pessoas trans. Tais processos possuem como participantes obrigatórios o experienciador e 0 fenômeno. No caso de P8, ela é experienciadora do fenômeno olhar, mas ela não é o alvo desse ato. É para ele que o fenômeno se volta e ele enquanto ser que é visto e subjugado. O que é diferente para P5, que coloca as pessoas como experienciadoras de um não-saber e, como P8 disse, se torna o alvo. Porém ele relata o alvo como não-visto, não-sabido. A subjugação acontece não pelo reconhecimento do corpo estranho, mas pelo não conhecimento do corpo. E como P5 exemplificou: "se elas não sabem, como elas vão respeitar?", é necessário o conhecimento para o reconhecimento (CANSECO, 2015). Em ambas as entrevistas, há a presença de intensificadores (muito, tempo inteiro, sempre) que reforçam a repetição do ato regulatório, em diferentes contextos e com produção de atores performáticos muito distintos entre si: mulher negra cis e homem branco trans. 
As ausências de dispositivos de reconhecimento trans são denunciados no decorrer das entrevistas:

- "Elas (travestis) não vão ao médico, elas não têm tratamento isonômico, elas não têm tratamento digno, elas são chacotas, são várias as que conversei e falaram 'Não, eu fui lá no posto e eu cheguei lá e mostrei e ficou gritando meu nome alto. Eu sou Maria!', 'Mas aqui no documento... mas você não é o João?' (P8)

- "eu ia especificamente pra lugares que eu sabia que a produção tinha algum mínimo interesse na pauta LGBT (...) só que isso não impede de nada (...) o segurança nem sabia o que era nome social, então ele não foi preparado pra isso e eu tentei explicar pra ele e ok, ele me deixou entrar, mas é sempre chato porque é como se você tivesse fazendo alguma coisa de errado (P5)

- "depois que ela (uma mulher em uma festa) descobriu que eu era homem trans, ela começou a me tratar no feminino (...) (ficou) me chamando de bichinha" (P5)

- "se eu tiver com dor de garganta e precisar ir no hospital, eu sei que eu vou passar por alguma humilhação, se eu precisar fazer um exame em qualquer lugar, que chame meu nome lá alto numa sala cheia de gente, eu vou passar por uma humilhação e aí isso eu já tive várias vezes" (P5)

Os excertos anteriores utilizam principalmente dos processos verbais, os dizentes - gritar, explicar, chamar - para relatar experiências violentas relacionadas com nome social ou gênero performatizado. Mesmo em ambientes que, por pressuposição, promoveriam respeito à diversidade como festas de pauta LGBT+ e serviços de saúde, acontecem episódios ou práticas institucionalizadas de violências. Existe, portanto, a reiteração da negação de direitos garantidos a outros grupos sociais hegemônicos. Isso culmina na produção de sujeitos úteis à chacota, à abjeção e à monstruosidade, muito parecido com outras estratégias do ethos coletivo para a imposição da naturalidade anacrônica. Assim a prática discursiva é iterada em diferentes espaços de relações (festas, serviços, etc.), capilarizando uma hegemonia cis. 
Chama-se atenção para as consequências do desrespeito ao nome social geradas no acesso ao sistema de saúde. Se o nome é entendido como "cartão de visitas" ou "senha" para entrar no serviço de saúde, chamar uma pessoa trans pelo nome registrado civilmente quando ela manifesta desejo, verbal ou corporalmente, por outro é negar direitos previstos na Carta dos Direitos dos Usuários da Saúde, na Lei n. 8080 de 1990 e em outros dispositivos legais (SILVA et al., 2017). Existe, assim, a negação como "morte" dos direitos da pessoa trans, porém P4 e P6 relatam outros momentos de morte, sem aspas:

- "já perdi um amigo no carnaval (...) foi uma travesti" (P4)

- "ela era travesti, ela foi assassinada na minha frente (...) ninguém ligou assim porque dizem que ela estava envolvida com drogas, essas coisas, então ninguém pode nem chegar muito perto" (P6)

Segundo dados do Grupo Gay da Bahia (2018), a cada 19 horas uma pessoa LGBT+ foi assassinada por conta de sua identidade, sendo $43 \%$ dessas vítimas performatizavam transgêneros (travesti, mulher trans, homem trans e andrógino). P4 traz o processo material de perder, de não possuir mais alguém que ela considerava como sua - no caso amiga. É nítido que o corpo trans está construído socialmente como abjeto, tabu e/ou excluído (SALIH, 2017), ligado no excerto de P6 a uma justificativa considerada plausível para sua morte. Não há reconhecimento de que a vida é precária, incompleta, vulnerável e que precisamos do outro para chamar de vida nossos atos repetidos e criados - ou pelo menos não é reconhecido aquele corpo transgenerificado, permitindo a violência e a ideia de vingança. Deixa-se morrer (SEFFNER, PARKER, 2016).

No caso de P6, Carrara e Vianna (2006) apontam que as investigações policiais são mais precárias quando envolvem travestis e envolvimento de drogas, ainda que não comprovadamente, além de sinalizar que esse grupo é o mais vulnerabilizado, pois, assim como são alvos principais pela despreocupação social de sua segurança, no momento de apurar o fato, também há certa negligência na responsabilização do crime. Assim,

A indiferença policial na apuração da maior parte desses crimes parece encontrar eco nas representações negativas de travestis como homossexuais especialmente 
desajustados, de modo que sua morte, em geral em idade bem inferior do que a das vítimas de latrocínio, tende a ser tomada por policiais como conseqüência de um modo de vida constantemente próximo da ilegalidade e que é recebida com poucas pressões, sobretudo familiares, por sua apuração e por justiça (CARRARA; VIANNA, 2006, p. 247).

P5 reforça essa ideia de corpo que é deixado para morrer:

- "essa violência é diária e é o tempo inteiro e não só na área da saúde, em qualquer lugar que eu for, que eu precise me identificar com minha carteira de identidade (...) além da minha carteira de identidade, ainda tem meu corpo ne!?" (P5)

- "essa questão também que você precisa de um laudo psiquiátrico pra começar qualquer coisa que você vá fazer, tipo uma hormonização ou fazer cirurgia, que já entra outro tipo de violência que é você pegar um atestado que tá dizendo ali que você é um doente mental (...) você tem que convencer o profissional de que você é um homem trans" (P5)

O processo relacional da violência dito por P5 atribui a ela o caráter permanente e onipotente: qualquer hora, todos os dias, em qualquer lugar. $A$ carteira de identidade, símbolo da cidadania brasileira, é vista como o instrumento de performance do seu gênero que, juntamente com seu corpo, são usados para diminuir sua cidadania, uma vez que P5 ainda não teve garantido o direito de retificação do registro civil. $O$ nome social é um direito a conta-gotas, que segue a lógica de incluir para seguir excluindo, "como se os atos de poder fossem dádivas" (BENTO, 2014, p. 174). A cidadania diminuta continua quando P5 cita o processo transexualizador e suas condições obrigatórias: laudo, doença e argumentação.

O laudo é o instrumento médico-legal que materializa um sulco por onde flui o poder, o qual uma pessoa cientificamente legitimada define o que um sujeito é ou tem. No caso de pessoas trans, elas têm de ser gênero-disfóricas. Esse termo sinaliza que a pessoa possui uma patologia motivada principalmente pelo seu gênero que a deixa triste, angustiada, melancólica e/ou pessimista. No 
caso de uma pessoa trans, mesmo que ela não se sinta assim, mas deseja modificar seu corpo para que possa performatizar outros gêneros, ela precisa argumentar por meio de exemplificações, enunciações e fatos espaçotemporais que corroborem com sua tese de que não faz o gênero que a designaram.

Nesse âmbito, a OMS publicou em 2018 a $11^{\text {a }}$ revisão da Classificação Internacional de Doenças, a qual excluem diagnósticos como "travestismo" e "transexualismo". No entanto permanecem as incongruências de gênero, entendidas como discrepâncias acentuadas entre o sexo experenciado de um indivíduo e o sexo atribuído (OMS, 2018). É um passo necessário para a despatologização, mas não suficiente, pois agora os países precisam ratificar essa mudança em seus protocolos assistenciais (e isso já envolve disputas de verdades), além de o termo "incongruência" ainda estar inserido em práticas cis-heteronormatizantes - exige-se que 0 indivíduo, para ser nomeado saudável, performatize o que the foi designado ao nascimento, imputando identidades que podem não corresponder aos desejos ontológicos do ser.

Bento (2016) aponta que a concepção de gênero nesse processo é de um corpo sexual dimórfico, que precisa estar sob a hegemonia médica que, aos poucos e caridosamente, negocia direitos, diminuindo a cidadania. Nitidamente a ordem do discurso médico impõe certa performatividade no corpo trans, em que os sujeitos legitimados por um saber-poder constrangem as vivências de outros, estabelecendo relações de dependência em vez de solidariedade.

A situação se agrava quando P5 atribui ao processo uma saída, uma redenção:

- "no começo, quando eu ainda não tava me hormonizando, essa coisa era diária, de eu sair na rua, qualquer lugar que eu fosse eu sofria algum tipo de humilhação (...) então eu tava louco pra começar a hormonização" (P5)

A mobilidade do corpo, segundo Butler (2018), já se constitui como um direito desse corpo, assim como pré-condição para exercício de outros direitos. 
Quando P5 é interpelado de modo a não sair na rua, interdita-se, por conseguinte, seu direito a ter direitos, principalmente o direito à dignidade, já que a humilhação estava ligada a esse estar na rua.

Essa iteração da humilhação é chamada por Barboza (2010) de transformação da pessoa trans em homo sacer contemporâneo, pois ela torna-se insacrificável por estar sob um grande guarda-chuva de direitos, porém matável, já que sua cidadania é negada, sem que alguém seja responsabilizado por essa violência. Tal vida nua do homo sacer é vivida por uma sociedade que não consegue enxergar a precariedade de sua existência coletiva. Tendo a certeza da suficiência de si, o outro não precisa estar nem ser em mim. Por isso a humilhação acontece, em qualquer lugar, uma vez que é a microexpressão dessa violência ethoica que define seres matáveis para reproduzir sua hegemonia. P5 continua com outra microexpressão:

- "na última festa que eu saí, eu tava com um amigo trans que um cara pegou no peito dele (...) já aconteceu isso comigo, da pessoa querer pegar no meu corpo" (P5)

O processo material desenvolvido (pegar), intermediado pelo tato, em que P5 é um dos alvos reitera a vida nua trans - esse corpo, inscrito em representação de promiscuidade e de indignidade, é regulado por normas de ordem cristã, médica e jurídica, que "permitem" o toque violento e agressor de outro. Este outro não é aquele de quem depende-se, advindo da ideia de precariedade da vida, mas sim o outro que deseja possuir, que enxerga a pessoa trans como exótica. Por fim, P5 exemplifica a vida nua quando sacrificada:

- "dentro da UFV tinha uma menina trans, ela era a única da universidade e ela sofria violência diária, era quase institucional da UFV (...) ela fazia parte dos movimentos feministas, ou tentava fazer parte, porque chegou uma hora que não foi permitido mais a ela, ela saiu da faculdade por causa disso e posteriormente cometeu suicídio por causa disso" (P5) 
A busca da cidadania, já interditada por mecanismos medicalizantes e jurídicos (BENTO, 2016), foi galgada por essa mulher trans na Universidade, apesar de ser outro dispositivo de controle dos corpos. $\mathrm{O}$ relato de P5 sobre a inserção dela em movimentos sociais é uma forma de estratégia de enfrentamento às violências vividas por ela, além do próprio ato de suicidar-se também o é, como discutiremos no item 6.4 .

Neste tópico sobre violências contra pessoas trans, as performatividades do entrevistado e de outras pessoas cis que convivem com travestis, homens trans e mulheres trans são delimitadas pelo tato e pela visão, seja por olhares de insultação ou perplexidade com "algo exótico" ou ainda pelo toque não autorizado de partes do corpo. As violências continuam pelo desrespeito ao nome social e pela sujeição às práticas discursivas médicas que regulam o processo transexualizador pelo SUS. Rocon et al. (2018), ao entrevistar pessoas trans, mostram que não há orientação por parte de profissionais de saúde sobre o processo hormonizador, não está disponível um serviço específico como o Ambulatório Trans, ausência de equipe multidisciplinar para acompanhamento de pacientes em processo de mudanças corporais, entre outras questões de direitos. A performance trans, portanto, é de luta.

\subsection{Sobre estratégias de enfrentamento}

As violências contra pessoas LGBT+ descritas e analisadas no tópico anterior impactam de diferentes formas o cotidiano das pessoas entrevistadas. Tais condições adversas provocam reações que os indivíduos produzem para lidar com esse cenário. São, portanto, chamadas de estratégias de enfrentamento ou coping, as formas intencionais (ações, pensamento e comportamentos) com que as pessoas administram determinado elemento estressor do ambiente ou estado interno (ANTONIAZZI; DELL'AGLIO; BANDEIRA, 1998). Será proposto, nessa parte da dissertação, analisar as estratégias de enfrentamento como atos e práticas iterados que constituem os sujeitos LGBT+, ao passo que são construídas por esses mesmos sujeitos. Inspira-se no conceito de 
performatividade de Butler $(2001 ; 2003)$ para estudar as estratégias de modo menos individualizante e mais próximos de práticas discursivas e corporais estabelecidas por atores na cena enunciativa de violência.

Para tanto, primeiramente, apresento trechos de estratégias de enfrentamento que possuem elementos em comum:

- "eu tenho um amigo também que me ajudou, ele que me segurou as barras, as rédeas" (P6)

- "meu amigo, sempre ajudo, ele vem, desabafa comigo, desabafa com os amigos" (P9)

- "Quando você tem amigos aí você consegue desabafar (...) se você tem amigos, você consegue até sobreviver, se você não tem, você não sobrevive não" (P2)

- "o máximo que eu poderia fazer é reclamar com um amigo ou outro" (P8)

- "se sua família não te apoia, você tem outras pessoas que te apoiam" (P7)

Os relatos apresentam a estratégia de enfrentamento mais recorrente nas entrevistas: a amizade. Estabelecida em processo relacional (ter), essa estratégia implica em um identificado (amigo) que realiza processos materiais ou verbais (ajudar, segurar, desabafar, reclamar, apoiar) e parece não haver interseccionalidades em sua ativação, mas sim homogeneidade dentro do conjunto de entrevistas, uma vez que diferentes ontologias acionam-na como principal forma de enfrentamento às violências. É produzida certa prática discursiva hegemônica na comunidade LGBT+ universitária, em que a amizade atravessa os discursos de todas(os) as(os) entrevistadas(os).

P6 e P2 metaforizam a amizade como algo que "segura as rédeas", ou seja, que está fora de controle e o amigo aparece para controlar e/ou sustentar a situação, ou ainda como condição para sobreviver. Neste último, é possível questionar se sobreviver não está no sentido literal, dado que o Brasil é o país 
que mais assassina pessoas LGBT+ no mundo (GRUPO GAY DA BAHIA, 2018). Amiga(o), portanto, para as pessoas participantes da pesquisa, é alguém que, solidário à situação de violência, intervém na situação emocional da vítima. Essa estratégia também foi uma das principais nos estudos de Albuquerque et al. (2016) e Vieira (2015), os quais a amizade aparece como um núcleo de apoio social que se contrapõe à família tradicionalista, heteronormatizada, célula menor da sociedade, aquela que nos designa pela linguagem, geralmente a primeira instância a excluir e violentar pessoas LGBT+. É circulado dentro da comunidade que amigos são a família que escolhemos - isso reflete a importância do lugar de amizade e põe em xeque a outra família.

Por outro lado, os mesmos estudos salientam que amigos também podem ser agentes das violências contra LGBT+, chegando a $39,8 \%$ o número de entrevistados da pesquisa de Albuquerque et al. (2016) que afirmaram já ter sofrido alguma forma de violência psicológica por pessoas identificadas como amigas.

Outra estratégia que também apareceu com bastante frequência foi a família, conforme os excertos a seguir.

- "eu tive apoio da família, eu tive apoio da instituição que estudo (...) então eu to dentro mesmo de uma bolha" (P5)

- "eu busquei apoio muito na minha família, apesar de elas não terem aceitado de primeira vez, falado que era mentira (...), mas depois perceberam que era verdade, que eu não tava inventando, elas foram meu porto seguro" (P6)

- "eu buscava apoio no meu avô. Meu avô é espírita então eu converso muito, muito, muito, muito com ele (...) procuro abrigo só no meu avô mesmo, que é o único que ainda consegue me compreender" (P4)

$\mathrm{Na}$ literatura científica é raro encontrar produções que demonstrem a família como porto seguro, parafraseando P6. Longaray e Ribeiro (2015) discutem o ambiente familiar como o primeiro espaço de socialização e educação de 
sujeitos LGBT+ e, assim, o lugar das primeiras dificuldades de reconhecimento de ontologias não hegemônicas. No entanto ainda é possível perceber dissidências desse status da família cis-heteronormativa, como P4 traz ao falar de seu avô. Ele é o único elemento da família que ela traz, e ao fazer isso, intensifica processos material (conversar) e mental (compreender) utilizando a repetição do muito e os operadores argumentativos só e único. Em encontros posteriores, a participante aponta que a avó também a compreende nesse cenário familiar. No entanto esse interdiscurso atravessado pelas práticas discursivas cristãs geralmente tende a controlar os corpos (ROCHA, 2008), imputando a ele a responsabilidade pela divisão sexual, geratrizes dos papéis "naturais" de cada sexo (BUTLER, 2002; GOUVÊA NETO, 2017). Porém se for um corpo que não é adequado à matriz fixa de inteligibilidade cristã, torna-se abjeto, ou seja, uma vida que não merece ser vivida, não importante.

A abjeção dos corpos ocorre dentro de um processo discursivo, no contexto social em que operam relações sociais e poderes com possibilidades de construir significados de acordo com seus interesses. (...). E é disso que se trata a abjeção, a sinalização de comportamentos e identidades que estão fora do esquema binário em que os sexos/gêneros estão inseridos (GOUVÊA NETO, 2017, p. 338).

Para sobreviver, portanto, as pessoas LGBT+ constroem relações com amigas e família na perspectiva da precariedade: devido a condições assimétricas sociais, os grupos veem-se interdependentes (BUTLER, 2011; SEFFNER, PARKER, 2016). Daí é possível questionar se a família que apoia e o grupo de amigas(os) também se percebe precariamente, uma vez que, assim como a pessoa vítima de violência depende delas, elas dependem dessa pessoa, combatendo, portanto, qualquer relação autônoma.

Outros dois participantes da pesquisa, P5 e P6, não diferenciam indivíduos específicos da família que auxiliaram no enfrentamento da violência. P6 afirma que, em função de uma situação de abuso sexual, realiza um processo material (buscar), não atingiu a meta de imediato (apoio) e reforça (mas) que em um momento posterior outro processo, agora mental (acreditar), se confluiu no enfrentamento à violência. Baía, Magalhães e Veloso (2014) apontam que a 
crença na criança vítima de abusos não acontece de forma plena no momento em que ela relata o ocorrido. São feitos questionamentos como identificação do agressor, verificação do ato e a confirmação por outras pessoas, principalmente profissionais de saúde, para que a família acredite na vítima. Se por um lado é importante averiguar todas as informações possíveis sobre abusos sexuais a fim de identificar corretamente a pessoa agressora e tomar as providências cabíveis, por outro a vítima fica sem apoio social, familiar e institucional até a confirmação do fato, podendo abrir uma janela temporal em que pode haver mais situações abusivas e prejuízo de diversas ordens para a vítima. Assim a estratégia de enfrentamento baseada na busca de algum auxílio constitui o sujeito, no sentido que, a partir do ocorrido, ele será interpelado pelo discurso culpabilizador, que deslegitima sua fala em detrimento da cena, até que outros atores, ao se relacionarem, provoquem novas práticas em cena. A repetição da busca de apoio na família acontecerá caso as experiências iniciais sejam percebidas com sucesso - caso contrário a pessoa LGBT+ vivenciará outros atos quando outras violências acontecerem. Portanto essas estratégias são performances que auxiliam na constituição do sujeito, à medida que é constituída por ele.

Continuando com as entrevistas, P5 descreve a família como uma bolha, a qual também está formada pela universidade em que estuda. Essa fala é estranha em relação à literatura sobre violência contra pessoa trans, já que são relatados suportes pontuais às pessoas travestis e transexuais como apoio clínico no processo de transexualização, apoio familiar, apoio institucional, mas não concomitantemente a ponto de ser metaforizado como uma "bolha" (PINTO; MOLEIRO, 2012). A interseccionalidade presente na performatividade de P5 pode auxiliar na compreensão dessa bolha - mesmo sendo homem trans, ele é branco, morador de uma cidade de grande porte, inserido na universidade, com vínculo empregatício e com renda fixa. Isso conforma suas vivências de modo a diminuir sua vulnerabilização. A metáfora da bolha itera a performatividade do corpo que é limitado, que tem a existência dentro de um limite. 
Outra estratégia de enfrentamento com muita recorrência nas entrevistas foi a não-estratégia, ou seja, a ausência de apoio externo e a dificuldade de lidar internamente com as violências é uma forma de enfrentar a violência. Assim a imutabilidade da situação é resultado da não-estratégia, de acordo com os excertos a seguir.

- "a gente fica com muito medo de fazer denúncia ou algo do tipo porque a gente sabe que não vai acontecer nada com a pessoa" (P5)

- "não teve nada, porque até então ninguém teve coragem de denunciar e então ficou por isso mesmo" (P6)

- "eu não tinha ninguém pra recorrer, sabe? Eu não conhecia muita gente LGBT (...) eu tive que enfrentar tudo sozinha, assim tive depressão durante um período" (P9)

- "você não busca apoio em lugar nenhum porque não tem esse lugar (...) raramente você vai ter esse lugar em casa (...) na maioria das vezes você tá sozinho" (P2)

P5 e P6 relatam a não-estratégia por meio da percepção de que as autoridades policiais não irão responsabilizar ou punir adequadamente as pessoas agressoras, utilizando-se de vivências trans - o primeiro relaciona o medo de denunciar a uma agressão sofrida por ser um homem trans enquanto que o segundo liga o processo relacional ter coragem a um episódio de feminicídio trans que presenciou. Há interdiscursividades acerca da não-estratégia coragem e enfrentar remetem a um universo de sentidos bélicos, como se as pessoas LGBT+ estivessem continuamente lutando. Essa constituição do ser que luta é por vezes solitária, podendo ocasionar depressão, como P9 aponta, e imobilidade por estar sozinho.

Mello, Avelar e Maroja (2012) apontam que segurança pública é a segunda pauta mais presente no Plano Nacional de Promoção da Cidadania e dos Direitos Humanos de LGBT, configurando-se, portanto, em demanda urgente há alguns anos para a garantia de direitos. Além disso, o Plano Nacional de Direitos Humanos de 2009 estabelece a criação de delegacias especializadas 
em crimes motivados por preconceitos de quaisquer ordens, organizando-se em redes integradas de atenção às populações vulnerabilizadas. Atualmente, as polícias civis de alguns estados, como Minas Gerais e São Paulo, ampliaram o escopo das já existentes delegacias especiais de crimes contra a mulher, à pessoa idosa e com deficiência para atender vítimas de crimes com motivação religiosa, racial ou identitária, ainda que este último não esteja tipificado no Código Penal brasileiro (RIBEIRO, 2012; SÃO PAULO, 2001).

Mesmo com tais conquistas, as vivências da comunidade LGBT+, em especial as das pessoas trans, ainda estão permeadas pela percepção de "que nada vai acontecer com a pessoa" ou que a segurança de quem denuncia não pode ser garantida pelas autoridades responsáveis. Os excertos de P5 e P6 exemplificam as considerações de Silva et al. (2016): pelo receio de mais violências, há poucos registros em boletins de ocorrência sobre atos criminosos infringidos à população trans, reforçando a invisibilidade. Ainda segundo as mesmas autoras, pessoas trans negras sofrem mais violência, corroborando com a perspectiva interseccional do fenômeno, já que raça atravessa o sujeito e é utilizada como atributo vulnerabilizador dentro do grupo trans.

Já P9 e P2 exprimem a não-estratégia pela ausência generalizada de apoio. Não ter ninguém e Não ter lugar são dois processos relacionais marcantes nos excertos, em que o portador nega qualquer atributo em relação ao apoio em situações de violência contra pessoas LGBT+. Essa solidão é explorada por algumas pesquisas (MONTEIRO, 2009; SOUZA, 2012) e pode levar a questionamentos existenciais: se não importa onde estou ou quem sou, para que vivo? O suicídio viria, então, como uma alternativa a essa existência cheia de nada, como uma forma de implementar novas formas de ser (ou de não ser) (TOLEDO; PINAFI, 2012).

A existência de espaços saudáveis, que possibilitem o encontro entre pessoas LGBT+ e valorizem suas experiências e demandas (VIEIRA, 2015), visa justamente propiciar a quem não tem lugar ou não tem ninguém a ressignificação de sua existência. Ao existir, sujeitos LGBT+ resistem. E a resistência, mesmo que isolada, conforma a luta de um grupo vulnerabilizado. 
Seguindo a mesma linha da negação como estratégia de enfrentamento, algumas pessoas entrevistadas relataram o não ser frente às violências cotidianas.

- "você se percebe gay, aí depois você se anula, você não aceita porque tem as questões religiosas (...) eu era um desses gays [afeminados] na infância, é porque você vai se retraindo, eu fui me retraindo porque eu percebia que não podia ser assim, porque se eu fosse assim, eu ia sofrer muito mais abusos do que eu já sofria (...) tenho vários amigos que se retraíram fisicamente, ficando mais masculinos, tentando ficar mais masculinos, pra sofrer menos opressões" (P2)

P2 fala de uma situação recorrente à comunidade LGBT+: primeiramente você percebe ser, depois não pode ser. A percepção pelos sujeitos de suas identidades sexuais e de gênero, quando não compatíveis com a norma cisheterossexual (ou quando são avisados disso, conforme apontamento de P2 anteriormente) é seguida pelo entendimento de que isso é motivo para ser atacado física, verbal ou psicologicamente. A estratégia então adotada para (sobre)viver é não (poder) ser. A prática discursiva, por conseguinte, restringe a performance a algo hegemônico - no caso, a religião interpela os sujeitos - e constitui a pessoa LGBT+. A paródia do masculino, feita pela repetição de atos moldados a partir de um ideário de homem que não existe, é iteração da pessoa gay em relação a um contexto percebido como assujeitador. Sua identidade, portanto, vai constituindo-se por corporeidades hegemônicas, ao mesmo tempo que se naturaliza como um eu, pretensamente autônomo e essencial. Assim internaliza-se o ethos violento para expressá-lo por efeitos de verdade através do corpo (SALIH, 2017; ROCHA, 2014).

Estratégia semelhante é adotada pela P8 quando é alvo de discriminação em situações que estava com sua companheira.

- "tinha que abaixar a cabeça e ir embora" (P8)

Adotando um processo material ligado a um relacional (ter que abaixar), ainda de maneira deôntica, como se algo a obrigasse, P8 explica a estratégia: 
abaixar e ir, produzindo um corpo subjugado e oprimido. Esse excerto pode ser entendido como slogan da forma subjugante à qual a comunidade LGBT+ tem vivido. Seja pela falta de apoio social para ter mais poderes, agir de maneira mais empoderada ou ainda para extinguir a origem das violências, o abaixar a cabeça e ir embora é uma forma individualizante (mas que se itera em várias vivências e práticas sociais) desse fenômeno, que imobiliza, invisibiliza e anula subetividades, além de naturalizar as violências cotidianas, pois o que resta é aceitar e seguir em frente.

Voltando-se para P8, que é negra e mulher cis, Barbosa et al. (2014) nos auxilia na análise ao problematizar as violências contra mulheres como a cisão entre os âmbitos público e privado. Como a mulher é definida - principalmente pela norma que itera performances do patriarcado - como corpo reprodutor dos costumes e sujeitos, seu privado (sexualidade) é destacado no público, no qual homens cis apontam, ofendem e agridem se percebem que a função feminina não está sendo conformada em uma mulher. A justificativa é manter a "ordem natural da vida", anulando qualquer individualidade em nome do coletivo. Se for negra, a função da mulher, além de reproduzir, é servir à hegemonia branca. A prática sociodiscursiva da religião é facilmente percebida, ao imputar aos corpos certas performances sexuais em busca de um bem comum que, na verdade, serve à ideologia sexista e machista.

Assim percebe-se que essa estratégia de "ir embora" é uma forma de resgatar algo do privado, mantendo-o em si, em vez de combater diretamente o agressor, o que, necessariamente, exporia (ainda mais) sua condição ontológica.

As vivências trans em relação às violências são destoantes das outras ontologias como é exemplificado pelo relato a seguir:

- "durante muito tempo, no começo da transição principalmente, eu parei de sair de casa muito quando não era necessário" (P5)

Esse relato apresenta a estratégia construída por um homem trans para lidar com a discriminação em relação a seu corpo transitório, que leva à limitação da 
vida. Percebe-se que a ação de sair ocorria quando foi interrompida por um agente não explícito que se justifica pelo "começo da transição". No entanto parece que não foi a transição em si que impedia P5 de sair, exceto quando era necessário, mas sim os atos violentos contra pessoas trans naturalizados na população brasileira, aqueles sem agente, rosto ou sobrenome (RONDINI; TEIXEIRA FILHO; TOLEDO, 2017). Esse corpo-limite, que é constituído pelo processo de transição, é interpelado por um turbilhão de práticas discursivas e age de forma a enfrentar novas situações com essa outra corporeidade. A estratégia de isolamento foi, para P5, repetição de atos (durante muito tempo) que restringiu suas relações sociais, buscando evitar constituir-se do outro, pois o percebia como prejudicial para si. No entanto, ao agir dessa forma, já se constituía pelo outro, uma vez que este o impedia de agir livremente.

Espaços coletivos como religião, movimentos sociais e outros são apresentados também como agentes possibilitadores de enfrentamento. P1 exemplifica isso com a religião:

- "na época não tinha muito acesso, muita informação sobre essas questões, então meu apoio naquele momento foi minha religião (...) minha fuga para esse momento foi mesmo na religião" (P1)

$\mathrm{Na}$ fala dele, ao se relacionar com o meu questionamento sobre as formas de apoio, P1, como portador, nega os atributos acesso e informação através de um processo relacional (ter), concluindo que a religião foi seu apoio ou fuga. Importante frisar que aqui o termo religião é utilizado em referência mais aos ensinamentos e menos à instituição Igreja, conforme frisado pelo participante em encontros posteriores. Não é comum encontrar afirmações que ligam positivamente a religião com questões LGBT+, apesar de ela poder proporcionar ressignificação de cenas violentas e aumentar a resistência às outras violências (Santos, 2012), como por exemplo o Diversidade Católica ${ }^{5}$, grupos de estudos espíritas e as religiões de matiz africana.

\footnotetext{
${ }^{5}$ Diversidade Católica define-se como "grupo de leigos católicos que procura conciliar a fé cristã e a diversidade sexual e de gênero, promovendo o diálogo e a reflexão, a oração e a partilha,
} 
Práticas discursivas religiosas que desqualificam as diversidades identitárias, construídas a partir de interpretações conservadoras de livros-base, principalmente a Bíblia no contexto brasileiro, são visíveis em espaços midiáticos, políticos e sanitários, inculcados no cotidiano social como algo da ordem do dever ser (NOLETO, 2016). As tentativas de portarias e leis que autorizem a prática clínica de reversão sexual, que retrocedem em direitos (já exíguos) conquistados e que reproduzam a hegemonia sob a égide da "Escola sem Partido" são alguns exemplos que advêm da instituição religiosa e busca limitar, senão exterminar, a comunidade LGBT+. As igrejas inclusivas aparecem como alternativa à exclusão das pessoas não-cis-heterossexuais das atividades eclesiais e da vida em comunidade religiosa. O modo de incluir é diferenciado: algumas ofertam um espaço valorizador das diversidades sexuais, de militância, atuando além dos muros dos prédios sagrados, já outras aceitam desde que vivam uma vida monogâmica, adotando discursos moralizantes com vistas ao relacionamento paródico ao heterossexual idealizado (NOLETO, 2016). Ao ser compreendida como um espaço que se vai quando está em perigo - por isso P1 relaciona religião a fuga - a religião tem potencial de proteger a comunidade LGBT+ e promover seu desenvolvimento identitário. Assim a interpelação pela Igreja não é monopolisticamente hegemônica, podendo contribuir para a afirmação de identidades não hegemônicas. Araújo (2014) reitera que essa afirmação deve ser contínua, a fim de provocar reflexões desse lugar de dissidência e vigiar para que a transgressão da norma eclesial só possa existir pela produção de outras normas não enviesadas pela cis-heteronormatividade.

Outras estratégias de enfrentamento relatadas pelas pessoas participantes buscam em outros espaços coletivos meios de enfrentar a violência:

- "dentro da militância eu fui tendo mais conhecimento, informação em relação a isso, então eu sei os meus direitos" (P5)

compreendendo que a salvação de Oristo e sua mensagem são para todos, sem distinção". Retirado da página <http://www.diversidadecatolica.com.br/>. Acesso em: 04 Jun. 2018. 
- "eu acho que meu espaço justamente que me dá muita força dentro da militância, dentro do movimento são os coletivos que você pode trocar ideia, você pode ter uma abertura de falar certo assunto (...) às vezes tem até esses grupos de Facebook, que às vezes têm coisas interessantes" (P7)

- "foi feita toda uma ação no carnaval com formulário para as pessoas colherem os dados, relatos de agressão que tivessem ocorrido na festa, nos eventos" (P1)

Os movimentos sociais aparecem como local de emancipação local, de resistência e de estratégias de empoderamento (P5 e P7) e como interventor de certa realidade (P1). A primeira identidade atribuída aos movimentos sociais é atravessada por processos ligados às relações abstratas (ter, ser, dar força) que possuem como atributos: direitos, conhecimentos, força, coisas interessantes. Tais abstrações provocam (e são provocadas por) construções concretas de intervenção no cotidiano, como P1 exemplifica através de um levantamento de dados sobre violências LGBT+ no carnaval, assim como na constituição dos sujeitos que as produzem.

A participação em movimentos sociais produz nos próprios sujeitos participantes outros olhares, outras formas políticas de viver. A performance das pessoas LGBT+ inseridas em movimentos sociais é redefinida não porque o cenário e as regras mudaram - já que as violências persistem - mas as pessoas envolvidas decidiram agir de modo a quebrar algo colocado como hegemônico. Essa decisão é feita de modo constrangedor, já que até as rupturas só podem acontecer dadas algumas condições de possibilidade (SALIH, 2012).

A militância também é relatada como estratégia de enfrentamento fora de movimentos sociais organizados:

- "em alguns momentos eu tenho que fazer uma afirmação da minha sexualidade como forma de levantar bandeira naquele espaço" (P1)

- 'você pode até ser gay, não ligo, mas beijar perto de mim é demais'. Então eu falo assim 'Já pensou se eu falasse isso com você, assim 'Ah, 
eu até gosto de hétero, mas você beijar perto de mim é demais'? (...) 'Alguém te questionar que você não pode beijar porque você é hétero? Qual a diferença do meu beijo pro seu?'. 'Ah, mas é diferente!'. 'Não, gato, não tem diferença nenhuma. A diferença tá no seu preconceito." (P2)

- "hoje em dia, alguém fala alguma coisa, geralmente as que falam são do meu meio, talvez elas vão ter menos coragem de fazer uma agressão porque eu entro e bato de frente (...). Talvez lá na rua eu não sei se eu daria conta de bater de frente." (P7)

"Levantar bandeira" é uma metáfora de um processo material, porém da ordem do simbólico. Ela se constitui pelo diálogo com o outro, em que a relação busca desconstruir a performance hegemônica pelo atravessamento de outras performances possíveis. A exposição pelo levantar bandeira é necessária justamente onde é preciso superar as condições indesejadas em que o corpo LGBT+ é subjugadamente exposto, ou ainda como parte de um processo maior de resistência política (BUTLER, 2018).

P2 exemplifica pelo beijo como esse atravessamento se dá pela argumentação baseada na incoerência do ethos anacrônico. Como o próprio diz:

- "é no diálogo que você consegue desconstruir essas pessoas" (P2)

No entanto, nem sempre é possível agir pela desconstrução, já que implica "bater de frente" em certas cenas em que o sujeito percebe ser incapaz de conseguir romper a posição dominante (ou suspeita-se de tal). P7 pondera sua militância, corroborando que a luta é coletiva, porém é no espaço cotidiano que a resistência (r)existe, individualizada e individualizante (COELHO, 2010). Por ser negro e do interior, como ele mesmo já disse antes, os sulcos das relações de poder corroem a superfície de seu corpo. Seu cabelo, sua pele, seu sotaque são alvos interseccionalizados do ethos violento, corroborado socialmente pelos atos de violência que sofre diariamente. Talvez por isso não consiga performatizar a luta a qualquer momento e o medo o restringe. 
Nesse mesmo espaço do cotidiano, que constrange e ao mesmo tempo possibilita a ruptura pelas pessoas LGBT, P5, P9 e P7 exemplificam cenas cotidianas de resistência:

- "esse meu amigo que trabalha comigo tentou explicar pra ela de todas as formas [sobre o nome social], não era falta de conhecimento" (P5)

- "o pai [do meu amigo] é muito, muito preconceituoso, eu tive que conversar com ele porque ele é muito agressivo. Teve um dia que ele veio me perguntar 'mas esse meio é como?'. Ele totalmente perdido, ele achando que tinha droga, aquele preconceito assim 'Ah, é doença'. (...) Aí eu conversei tudo com ele e ele ficou mais calmo (...). Depois de eu ter conversado com ele, ele deu uma amenizada." (P9)

- "eu que não tinha amizade na época, eu ainda não era apresentada ao mundo LGBT, tudo que eu sabia, eu tinha que procurar na internet (...). O que eu tinha de preconceito foi embora, sabe? Aquela sementinha que foi plantada de preconceito foi embora a partir daí e foi assim, só pela internet mesmo" (P9)

A informação aparece aqui como principal aliada na resistência às violências, seja a pessoa LGBT+ na posição de disseminador de conhecimento - ainda que o outro se mantenha possuído de si e não permita permeabilidade - ou como aquela que procura conhecimentos para construção de sua identidade. No primeiro caso, a ruptura do ethos é buscada pelo diálogo, pelo processo verbal explicar, conversar, ainda que modalizado pelo tentar ou ter. Isso indica que tal ruptura está condicionada por limites, já que não há certeza de que uma conversa sobre nome social ou sobre cultura LGBT+ irá, necessariamente, garantir que pessoas comecem a respeitá-los. A performatividade promovida pelas estratégias de enfrentamento depende de atos aceitos e inteligíveis, por circunstâncias apropriadas e procedimentos completos (BUTLER, 2003; MINGO; MORENO, 2017). Pelo relatado, P9 cumpre essas três condições para que a conversa com o pai de seu amigo o tenha constituído de outra forma que não violento para com o filho - pelo menos não da mesma maneira. 
Já no segundo excerto, quando P9 fala da busca por elementos que possam auxiliar na construção de sua performatividade, a internet é posicionada como central e única. A falta de referências LGBT+ já foi falada por P5 ao relatar anteriormente e a internet, por possibilitar a circulação de símbolos de modo muito rápido, pode facilitar a identificação com performances trans, lésbicas, gays, bissexuais, entre outras, além de ser possivel compartilhar estratégias de enfrentamento em redes sociais e sites especializados. A interdiscursividade religiosa permanece na metáfora da sementinha, porém é destituída de legitimidade por disputar sentidos com as práticas discursivas informacionais.

Depois de analisadas as estratégias de enfrentamento relatadas pelas(os) participantes da pesquisa, foi possível compreender que a busca de apoio pelas relações de amizade é a principal forma de lidar com as violências contra pessoas LGBT+. Resultado semelhante foi o encontrado por D'haese, Dewaele e Houtte (2015), Bogart et al. (2016), Freeland, Goldenberg e Stephenson (2016), Gilbert et al. (2016), Arístegui et al. (2017), Eliason, Streed Jr. e Henne (2017) e Toomey et al. (2017). Mesmo sendo indicada como igualmente perpetradora da violência (HEQUEMBOURG; BRAILLER, 2009), a predominância é de ser mais acolhedora. $O$ oposto acontece com a família, que geralmente é apontada como a primeira cena violenta, pois é a ela indicada a missão de impor um gênero, aparecendo, também, como protetiva e afirmativa de identidades não hegemônicas. Estudos como o de D'haese, Dewaele e Houtte (2015), Ephrem e White (2011) e Goldbach e Gibbs (2017) também mostram essa flexibilidade de interpelações feitas pelo ente denominado família. Essa variedade de ações de amigos e família também vai depender dos sulcos de poder sob o corpo LGBT+, homens brancos e com determinado status econômico possuem condições de influenciar a cena enunciativa de modo a torná-la menos violenta, se comparado a outras interseccionalidades. Pessoas negras e mais ligadas à esfera feminina, por exemplo, são fortemente constrangidas à abjeção, permanecendo, por vezes, imóveis, resultando na não-estratégia. Tal forma de se constituir perante as violências pode resultar até mesmo na aniquilação desse sujeito ou ainda na sua ação visando paródias de modelos hegemônicos, como acontece com 
homens gays e bissexuais que vão se construindo desafeminados para encaixe em um molde de ilusões ideias. Este corpo modificado e constrangido a todo tempo é um corpo-limite, limitado em sua forma, em sua performance, em sua identidade. Como não é possível sair de todas as práticas discursivas, pois somos justamente por estar nelas, busca-se por espaços saudáveis como igrejas afirmativas e movimentos sociais que promovam outras práticas, convergentes com identidades LGBT+, ou mesmo, através do diálogo, os sujeitos criam cenas afirmativas das diversidades. Sendo assim, tais estratégias de enfrentamento transcendem a qualquer sistema fechado de estímulo-resposta para serem compreendidas como atos performativos, que auxiliam na constituição da pessoa LGBT+ ao mesmo tempo em que são praticadas por ela. 


\section{CONSIDERAÇÕES FINAIS}

Nessa dissertação busquei compreender as narrativas de pessoas LGBT+ que relataram as violências sofridas ou presenciadas por conta de performatividades de gênero e/ou orientações sexuais. Durante as entrevistas, pude compreender que a comunidade LGBT+ universitária tem performatizado um modo de vida a que chamo de vigilante.

Existe uma ordem hegemônica, que apesar de provisória, estabelece-se pelo ethos como onipresente, única e natural. Todas essas ilusões são provocadas pela repetição e reprodução de práticas discursivas em dispositivos como religião, mídia, escola, família. Assim o ethos violento atravessa corpos de modo a torná-los instrumentos e locus, ao mesmo tempo, da norma. Mas que norma é essa? Pode ser entendida como conjunto de valores e imagens que visam formatar os discursos e as práticas, aludindo a um ideal de, no caso de gêneros e sexualidades, homem cis heterossexual branco e abastado. Esse corpo ideal, de fato, não existe devido à diversidade humana e, portanto, quem pretende alcançá-lo estará senão parodiando-o, ou seja, performatizando cópias grosseiras de algo inumano. No entanto, sendo hegemônico, tal ethos disputa sua sobrevivência com outras práticas sociodiscursivas ditas contrahegemônicas, que valorizam ontologias múltiplas. Pessoas LGBT+, portanto, entram nessa disputa pelo direito de ser. $E$ a disputa acontece a todo momento e em qualquer lugar, conforme as entrevistadas relataram: no bar, no carnaval, na rua, dentro de casa, na universidade. As armas LGBT+ contra a hegemonia ethoica violenta são tão variadas quanto as identidades da sigla: adereços, gírias, músicas, bandeiras, paradas do orgulho.

O desenrolar cotidiano dessas disputas provocam a vida vigilante: nunca se sabe quando a pessoa LGBT+ receberá uma lâmpada na cara, será apedrejada ou mesmo servirá de subsídio para piadas. Todas essas cenas violentas parecem estar potencialmente presentes onde quer que a heteronorma - aquela norma do outro, inalcançável, porém aparentemente obrigatória - seja perceptível ou esteja apenas latente, como nos relatos de um participante da pesquisa sobre festas LGBT+. Pela constante presença de algo 
que te impeça de ser, a contra-hegemonia também precisa ser constante, vigilante, seja para transformar a cena, seja para conformar-se.

A transformação nessa vida vigilante ocorre na defesa, a todo instante, de um modo de viver legítimo, que precisa ser respeitado em suas características. Então utiliza-se daquelas armas contra-hegemônicas para marcar presença LGBT+, para gritar por direitos, para impedir retrocessos. No entanto não é todo local que pode ser de confronto direto - por isso uma das participantes da pesquisa busca rotas para sair. Não é incomum ser taxado como único gay da família ou a sapatona do bairro. Daí a estratégia de enfrentamento performatizada torna-se a conformação: para o corpo resistir, precisa externalizar atos-padrão, facilmente aceitos e aprovados, já que estão dentro da norma. Caso não seja, sua exclusão física ou simbólica é certa. Metaforizando, vida vigilante de conformação aponta suas câmeras de monitoramento para dentro, e a de transformação as direciona para fora. Sabemos que a direção das câmeras indica onde está o perigo.

Esses modos de vida que construímos à medida que nos foram impostos servem de subsídio para intervenções coletivas. Políticas públicas mais abrangentes, que considerem as diferenças intragrupais e que sejam construídas com a participação da comunidade LGBT+ podem auxiliar na luta contra-hegemônica de uma sociedade que, hoje, é insustentável pelas violências que reproduz. Tal necessidade é urgente devido às estratégias de enfrentamento aqui analisadas, que são sintomas da falta de proteção social, da (re)produção de um Estado negligente e/ou violentador e da ausência de dispositivos legais e jurídicos que proporcionem discursos e instrumentos de luta e resistência para a comunidade LGBT+.

Essa pesquisa possui limitações que, apesar de não diminuir a riqueza de informações sobre a comunidade LGBT+ universitária, instiga novas pesquisas e intervenções a avançarem. Uma delas foi não ter conseguido entrevistar mulheres trans, talvez pela metodologia que tenha dificultado acessar esse grupo ou pelas restrições de entrada e permanência delas no Ensino Superior. Outro ponto que merece atenção é todas as pessoas entrevistadas estarem ou 
já terem concluído um curso de graduação. Como já descrito, não era objetivo inicial da pesquisa investigar as vivências de pessoas universitárias, no entanto foram as que aceitaram participar. Isso, no mínimo, fornece pistas para indagações e reflexões: por que só pessoas universitárias? Quais e como são as violências de quem não possui o privilégio da escolaridade? Performatizam estratégias de enfrentamento semelhantes?

Termino retornarndo ao título e buscando responder se a resistência é individual e se é possível adotar o pressuposto de que a luta é coletiva. Através e com as(os) participantes deste trabalho, pude compreender a luta por direitos de pessoas LGBT+ como algo construído no entre corpos, ainda que entre corpos-limite. Daí o caráter coletivo da luta: o embate contra dispositivos e instituições cis-heteronormatizantes por uma vida boa de viver. Alguns resultados na política e no judiciário brasileiro favoráveis à nossa comunidade são exemplos de lutas coletivas. E quando um corpo está sozinho, dentro da ambiente familiar, torna-se alvo de violências baseadas em preconceitos de gêneros e/ou orientações sexuais e busca enfrentar a família: a resistência então não seria individual? Talvez apenas na superfície de algumas cenas violentas exista a individualidade da resistência ou talvez sea que a resistência é individualizada pelo ethos violento, já que é mais fácil exterminar um corpo isolado do que uma assembleia. Constituiria, portanto, estratégia hegemônica de enfraquecimento desse corpo que é coletivo - uma pessoa LGBT+ é atravessada por marcadores sociais que representam percursos históricos e políticos que transcendem sua própria história e que, justamente, a constituem enquanto corpo dissidente de e resistente a normas cis-heterossexuais. Quando atacado pela família, pela polícia ou por profissionais de saúde, o corpo-limite LGBT+ é entendido como corpo que carrega a categoria social, logo impedi-lo de ser é buscar impedir a existência desse grupo. Voltamos, então, ao argumento de que o ethos caça suas próprias contradições para manter-se no hoje, apesar de compartilhar valores e símbolos de outras épocas, e assim naturalizar-se no cotidiano. Isso reforça a tese de que a resistência é indivualizada pelo ethos, porém não é individual, uma vez que (r)existir é bancar ontologias das diversidades, é sustentar toda uma 
comunidade onde não é possível a presença de outros corpos, é corporificar multidões.

Essa pesquisa continua nas resistências individuais e nas lutas coletivas, no entanto essa dissertação encerra-se como um ato político, de busca pela transformação de nossas vidas, vigilantes sim, porém não mais vigiadas. 


\section{REFERÊNCIAS}

ALBUQUERQUE, Grayce Alencar et al. Violência psicológica em lésbicas, gays, bissexuais, travestis e transexuais no interior do Ceará, Brasil. Saúde debate, Rio de Janeiro, v. 40, n. 109, p. 100-111, Jun. 2016.

ALMEIDA, Aline. Evasão escolar entre travestis é bem maior. Flacso na mídia, 23 Mai. 2016. Disponível em: <http://flacso.org.br/?p=15833>. Acesso em: 19 Mar. 2018.

ANTONIAZZI, Adriane Scomazzon; DELL'AGLIO, Débora Dalbosco; ANDEIRA, Denise Ruschel. O conceito de coping: uma revisão teórica. Estud. psicol. (Natal), Natal, v. 3, n. 2, p. 273-294, Dez. 1998.

ARAÚJO, Murilo Silva de. "O amor nos uniu": construções identitárias e mudança social em narrativas de vida de gays cristãos do grupo

Diversidade Católica. Dissertação (Mestrado em Letras) - Universidade Federal de Viçosa, Viçosa, 144 f. 2014.

ARENDT, Hannah. Da violência. São Paulo: Record, 2004.

ARÍSTEGUI, Inés et al. Resources to cope with stigma related to HIV status, gender identity, and sexual orientation in gay men and transgender women. Jour. Health Psi., v. 23, n. 2, p. 320-331, 2017.

BAIA, Pedro Augusto Dias; MAGALHAES, Celina Maria Colino; VELOSO, Milene Maria Xavier. Caracterização do suporte materno na descoberta e revelação do abuso sexual infantil. Temas psicol., Ribeirão Preto, v. 22, n. 4, p. 691-700, Dez. 2014.

BARBOSA, Bruno Rafael Silva Nogueira et al. Invisibilidade lésbica e a interseccionalidade de opressões. In: $\mathbf{1 8}^{\circ}$ REDOR - Perspectivas Feministas de Gênero: Desafios no campo da Militância e das Práticas. UFRPE.

BARBOZA, Heloisa Helena Gomes. Procedimentos para redesignação sexual: um processo bioeticamente inadequado. Tese (Doutorado em 
Saúde Pública) - Escola Nacional de Saúde Pública Sergio Arouca, Rio de Janeiro, 174 f. 2010.

BATISTA, Karla Christianne Cardoso. Judith Butler, a performance e a psicanálise: um estudo epistemológico. Dissertação (Mestrado em Psicologia) - Universidade Católica de Brasília, Brasília, 128 F. 2007.

BEAUVOIR, Simone de. O Segundo Sexo. 1. Mito e Realidade. Rio de Janeiro: Nova Fronteira, 1980.

BENTO, Berenice. Nome social para pessoas trans: cidadania precária e gambiarra legal. Contemporânea. Revista de Sociologia da Ufscar, São Carlos, v. único, p. 165-185, 2014.

Disforia de gênero: geopolítica de uma categoria psiquiátrica. Revista Direito e Práxis, Rio de Janeiro, v. 07, p. 496-536, 2016.

Do luto à luta: pelo fim do transfeminicídio. Outras Palavras, 20/03/2017. Disponível em: <http://outraspalavras.net/brasil/do-luto-a-luta-pelofim-do-transfeminicidio/>. Acesso em: 11 Mai. 2018.

BILGE, Sirma. Théorisations féministes de l'intersectionnalité. Diogène, Paris, v. 1, n. 225, p. $70-88,2009$.

BOGART, Laura M. et al. Coping with discrimination among HIV-positive Black men who have sex with men. Culture, Health \& Sexuality, n. 19, v. 7, p. 723737, 2016.

BONAMINO, Alicia et al. Os efeitos das diferentes formas de capital no desempenho escolar: um estudo à luz de Bourdieu e de Coleman. Rev. Bras. Educ., Rio de Janeiro, v. 15, n. 45, p. 487-499, Dez. 2010.

BORBA, Rodrigo. A linguagem importa? Sobre performance, performatividade e peregrinações conceituais.Cad. Pagu, Campinas, n. 43, p. 441-474, Dec. 2014 .

BOURDIEU, Pierre. O poder simbólico. Lisboa: Disfel, 1989. 311 p.

A dominação masculina. Rio de Janeiro: Bertrand Brasil, 2002. 160 p. 


\section{BLACK PAGES BRAZIL. Origem e significado da palavra preto(a) e} negro(a). 19 Set. 2017. Disponível em:

<http://blackpagesbrazil.com.br/?p=1971>. Acesso em: 19 Mar. 2018.

BRAH, Avtar. Diferença, diversidade, diferenciação. Cad. Pagu, Campinas, n. 26, p. 329-376, Jun. 2006.

BRASIL. Ministério da Saúde (MS). Política Nacional de Saúde Integral de Lésbicas, Gays, Bissexuais, Travestis e Transexuais - LGBT. Brasília: MS; 2008.

BRASIL. Supremo Tribunal Federal. Ação Direta de Inconstitucionalidade $\mathrm{n}^{\circ}$ 5543. Brasília, DF, 09 de novembro de 2017. Diário Oficial da União. Brasília, 10 nov. 2017. Disponível em:

$<$ https://www.jusbrasil.com.br/diarios/documentos/518939773/andamento-doprocesso-n-5543-acao-direta-de-inconstitucionalidade-09-11-2017-dostf?ref=topic_feed>. Acesso em: 14 maio 2018.

BRASIL. Conheça as principais lutas e conquistas das mulheres.

Cidadania e Justiça. 8 Mar. 2017. Disponível em:

<http://www.brasil.gov.br/cidadania-e-justica/2017/03/conheca-as-principaislutas-e-conquistas-das-mulheres>. Acesso em: 19 Mar. 2018.

BUTLER, Judith. Como os corpos se tornam matéria. Estudos Feministas, Florianópolis, ano 10, p. 155-167, 2002.

Problemas de Gênero: Feminismo e Subversão da Identidade. Rio de Janeiro: Civilização Brasileira, 2003 [1990]. Performatividad, precariedad y políticas sexuales. Rev. Antropol. Iberoamer., Madrid, v. 4, n. 3, p. 321-336, 2009.

Bodies that matter: On the Discursive Limits of "Sex". New York: Routledge, 2011 [1993]. . Regulações de gênero. Cad. Pagu, Campinas, n. 42, Jan./Jun. 2014. 
Relatar a si mesmo: crítica da violência ética. Belo Horizonte: Autêntica, 2015a. 198 p.

Quadros de Guerra: quando a vida é passível de luto. Rio de Janeiro: Civilização Brasileira, 2015b. 288 p.

. Corpos em aliança a política de ruas: notas para uma teoria performativa de assembleia. Rio de Janeiro: Civilização Brasileira, 2018. 199 p.

CAMPOS, Rosana Onocko. Fale com eles! o trabalho interpretativo e a produção de consenso na pesquisa qualitativa em saúde: inovações a partir de desenhos participativos. Physis, Rio de Janeiro, v. 21, n. 4, p. 12691286, dez. 2011.

CANSECO, Alberto E. F. Reconocer la violencia. Sex., Salud Soc. (Rio J.), Rio de Janeiro, n. 19, p. 133-148, Abr. 2015.

CARRARA, Sérgio; VIANNA, Adriana R. B.. "Tá lá o corpo estendido no chão...": a violência letal contra travestis no município do Rio de Janeiro. Physis, Rio de Janeiro, v. 16, n. 2, p. 233-249, 2006.

CHALUB, Juliana Vieira. Reflexões sobre o ethos do discurso. Rev. (Com)Textos Ling., Vitória, v. 9, n. 14, p. 161-176, 2015.

COELHO, Maria Claudia. Narrativas da violência: a dimensão micropolítica das emoções. Mana, Rio de Janeiro, v. 16, n. 2, p. 265-285, Out. 2010.

COLLING, Leandro; SOUSA, Alexandre Nunes de; SENA, Francisco Soares. Enviadescer para produzir interseccionalidades. In: OLIVEIRA, João Manuel de; AMÂNCIO, Ligia. Géneros e sexualidades: interseções e tangentes. Lisboa: CIS-IUL, 2017, p. 193-216.

CONSELHO NACIONAL DE JUSTIÇA. Formas de violência contra a mulher. Disponível em: http://www.cnj.jus.br/programas-e-acoes/lei-maria-dapenha/formas-de-violencia. Acesso em: 09 Out. 2017.

CRENSHAW, Kimberle Williams. A intersecionalidade na discriminação de raça e gênero. In: VV.AA. Estudos Feministas. Brasília: Unifem, 2004. 
. "Mapping the Margins: Intersectionality, Identity Politics, and Violence Against Women of Color". In: Martha Albertson Fineman, Rixanne Mykitiuk, Eds. The Public Nature of Private Violence. New York: Routledge, 2016, p. 93-118.

D'HAESE, Lies; DEWAELE, Alexis; VAN HOUTTE, Mieke. Coping with antigay violence: in-depth interviews with Flemish LGB adults. The Journal of Sex Research, v. 52, n. 8, p. 912-923, 2015.

DIAS, Diego Madi. Brincar de gênero, uma conversa com Berenice Bento. Cad. Pagu, Campinas, n. 43, p. 475-497, Dez. 2014.

DICIONÁRIO do Aurélio de Português online. Disponível em: $<$ https://dicionariodoaurelio.com>. Aceso em: 19 Mar. 2018.

ELIASON, Michele J.; STREED JR., Carl; HENNE, Michael. Coping with stress as an LGBTQ+ health care professional. Journal of Homosexuality, v. $65, \mathrm{n}$. 5 , p. 561-578, 2017.

FAIRCLOUGH, Norman. Discurso e mudança social. Brasília: UnB. 2001. $316 \mathrm{p}$.

Analysing discourse: textual analysis for social research. London: Routledge, 2003.

FARIA, Mateus Aparecido de; SILVA, Analise de Jesus da. Análise das teorias pedagógicas presentes no projeto pedagógico do curso de formação em Gestão de Serviços de Saúde da UFMG. Rev. Bras. Cien. Saúde, João Pessoa, v. 20, n. 1, p. 43-50, 2016a.

. Gestão de serviços de saúde: analisando a identidade na graduação.

Saúde em Debate, Rio de Janeiro, v. 40, n. 108, p. 95-105, 2016b.

FARIA, Mateus Aparecido de; GOMES, Maria Carmen Aires; MODENA, Celina Maria Modena. Violências contra pessoas LGBT: o que a literatura aponta? In: I Congresso Mineiro de Psicologia, Gênero e Diversidade Sexual. Una, Belo Horizonte, 2017. 
FERNANDES, Felipe Bruno Martins. Assassinatos de travestis e \&pais de santo\& no Brasil: homofobia, transfobia e intolerância religiosa. Saúde debate, Rio de Janeiro, v. 37, n. 98, p. 485-492, Set. 2013.

FERNANDES, Gleiciane Benfica; GAIA, Vanessa Oliveira; ASSIS, Cleber Lizardo de. Estratégias de enfrentamento da violência de gênero em mulheres de Ji-Paraná (RO). Advances in Health Psychology, v. 22, n. 2, p. 1-14, Jul.Dez., 2014.

FREELAND, Ryan; GOLDENBERG, Tamar; STEPHENSON, Rob. Perceptions of informal and formal coping strategies for intimate partner violence among gay and bisexual men. Am. Jour. Men's Health, v. 12, n. 2, p. 302-312, 2016.

FREITAS, James Deam Amaral. Continuidade e rupture nos estudos de gênro - historiografia de um conceito. OPSIS, Catalão, v. 11, n. 1, p. 15-30, 2011.

GANGLIANONE, Isabela. Reconhecimento e violência ética. O Benedito, 21 Mar. 2016. Disponível em: <https://obenedito.com.br/reconhecimento-eviolencia-etica/>. Acesso em: 19 Mar. 2018.

GILBERT, Paul A. et al. Saliendo adelante: stressors and coping strategies among immigrant latino men who have sex with men in a nontraditional settlement state. Am. Jour. Men's Health, v. 10, n. 6, p. 515-525, 2016.

GOUVÊA NETO, Ana Luísa. O uso político da religião e o uso religioso da política: como a defesa de pautas morais indica uma compreensão de gênero. Interações, Belo Horizonte, v. 12, n. 22, Ago./Dez. 2017.

GRUDA, Mateus Pranzetti Paul. Uma análise do discurso do humor. Travessias, ed. XI, v. 5, p. 747-760, 2011.

GRUPO GAY DA BAHIA. Mortes violentas de LGBT no Brasil - Relatório 2017. Disponível em:

<https://homofobiamata.files. wordpress.com/2017/12/relatorio-2081.pdf>. Acesso em: 19 Mar. 2018.

GRUENEWALD, Jeff. Are anti-LGBT homicides in the United States unique? Journal of Interpers. Viol., v. 27, n. 18, p. 3601-3623, 2012. 
JESUS, Jaqueline Gomes de. Orientações sobre a população transgênero: conceitos e termos. Brasília: Autora, 2012.

KUHAR, Roman; SVAB, Alenka. The only gay in the village? Everyday life of gays and lesbians in rural Slovania. Journal of Homosexuality, v. 61, p. 10911116, 2014.

LACOMBE, Andrea. De entendidas e sapatonas: socializações lésbicas e masculinidades em um bar do Rio de Janeiro. Cad. Pagu, Campinas, n. 28, p. 207-225, Jun. 2007.

LADEIA, Priscilla Soares dos Santos; MOURÃO, Tatiana Tscherbakowski; MELO, Elza Machado de. O silêncio da violência institucional no Brasil. Rev. Méd. Minas Gerais, Belo Horizonte, v. 26, supl. 8, p. 398-401.

LOSERT, Annett. Coping with workplace heteronormativity among lesbian employees. Journal of Lesbian Studies, v. 12, n. 1, p. 47-58, 2008.

LOURO, Guacira Lopes. Gênero, sexualidade e educação: uma perspectiva pós-estruturalista. Petrópolis: Vozes, 1997.

LONGARAY, Deise Azevedo; RIBEIRO, Paula Regina Costa. Espaços educativos e produção das subjetividades gays, travestis e transexuais. Rev. Bras. Educ., Rio de Janeiro, v. 20, n. 62, p. 723-747, Set. 2015.

MACEDO, Elizabeth. As demandas conservadoras do movimento Escola sem Partido e a Base Nacional Curricular Comum. Edu. Soc., Campinas, v. 38, n. 139, p. 507-524, 2017.

MAGALHÃES, Simone Maria. Poder e violência: Hannah Arendt e a Nova Esquerda. Dissertação (Mestrado em Ciências Sociais) - Faculdade de Filosofia e Ciências, Universidade Estadual Paulista, Marília. 128 f. 2008.

MARTINS, Marco Antonio Matos; FERNANDEZ, Osvaldo; NASCIMENTO, Érico Silva do. Acerca da violência contra LGBT no Brasil: entre reflexões e tendências. In: Fazendo Gênero 9 - Diásporas, Diversidades, Deslocamentos. Anais...: Florianópolis, 2010. Disponível em: <http://www.fazendogenero.ufsc.br/9/resources/anais/1278500487_ARQUIVO_ 
ACERCADAVIOLENCIACONTRALGBTNOBRASIL.pdf>. Acesso em: 21 Mai. 2018.

MASON, Marilyn J.. Vergonha: reservatório dos segredos na família. In E. Imber-Black (Org.), Os segredos na família e na terapia familiar. Porto Alegre: Artmed, 2002

MELLO, Luiz; AVELAR, Rezende Bruno de; BRITO, Walderes. Políticas públicas de segurança para a população LGBT no Brasil. Rev. Estud. Fem., Florianópolis, v. 22, n. 1, p. 297-320, Abr. 2014.

MELLO, Luiz; AVELAR, Rezende Bruno de; MAROJA, Daniela. Por onde andam as políticas públicas para a população LGBT no Brasil. Soc.

estado., Brasília, v. 27, n. 2, p. 289-312, Ago. 2012.

MELLO, Luiz; BRITO, Walderes; MAROJA, Daniela. Políticas públicas para a população LGBT no Brasil: notas sobre alcances e possibilidades. Cad. Pagu, Campinas, n. 39, p. 403-429, Dez. 2012.

MELLO, Luiz; GONÇALVES, Eliane. Diferenças e interseccionalidades: notas para pensar práticas em saúde. Cronos Rev. PPG Ciencias UFRN, Natal, v. 11, n. 2, p. 163-173, 2010.

MINAYO, Maria Cecília de Souza (org.). Pesquisa Social. Teoria, método e criatividade. 18 ed. Petrópolis: Vozes, 2001.

MINAYO, Maria Cecília de Souza. Violência e saúde. Rio de Janeiro: Editora Fiocruz; 2006.

. Amostragem e saturação em pesquisa qualitativa: consensos e controvérsias. Rev. Pesq. Qualitativa, São Paulo, v. 5, n. 7, p. 1-12, Abr. 2017. MINGO, Araceli; MORENO, Hortensia. Sexismo em la universidad. Estud. sociol, México, v. 35, n. 105, p. 571-595, Dez. 2017.

MISKOLCI, Richard. A Teoria Queer e a Sociologia: o desafio de uma analítica da normalização. Sociologias, Porto Alegre, ano 11, n. 21, p. 150-182, Jan./Jul. 2009. 
MONTEIRO, Luciana Fogaça. Rompendo o silêncio: homofobia e heterossexismo nas trajetórias de vida de mulheres. Dissertação (Mestrado em Psicologia Social e Institucional). Universidade Federal do Rio Grande do Sul, Porto Alegre, 2009. $122 \mathrm{f}$.

MORAIS, Ricardo Manoel de Oliveira. Norma, gênero e representatividade: um estudo a partir do pensamento de Judith Butler. Revista Eletrônica Direito e Política, Programa de Pós-Graduação Stricto Sensu em Ciência Jurídica da UNIVALI, Itajaí, v.10, n.3, $2^{\circ}$ quadrimestre de 2015.

MORAES, Dayane Suelen de; SILVEIRA JUNIOR, Luiz Alberto da Silva; LUCKOW, Helioza Iracema. As trajetórias escolares de alunos LGBT: um levantamento de produções bibliográficas. In: XII EDUCERE - PUC-PR, Curitiba, 2015.

MOREIRA, Yan Faria. Saindo do armário e da escola: índices e causas de evasão de indivíduos não heterossexuais das instituições de ensino. In: Anais Seminário Nacional de Educação, Diversidade Sexual e Direitos Humanos. UFES, Vitória, 2012.

MOREIRA FILHO, José Lopes. Kitconc 4.0. 2008. Disponível em: <http://www.fflch.usp.br/dl/li/x/?p=394>. Acesso em: 03 Out. 2017.

NATARELLI, Taison Regis Penariol et al. O impacto da homofobia na saúde do adolescente. Esc. Anna Nery, Rio de Janeiro, v. 19, n. 4, p. 664-670, 2015.

NININ, Maria Otilia Guimarães. A atividade de observação nas práticas de orientação a professores: uma perspectiva crítica. DELTA, São Paulo, v. 25, n. 2, p. 347-400, 2009.

NOLETO, Rafael da Silva. Religião e sexualidade: dilemas contemporâneos brasileiros. Cad. Pagu, Campinas, n. 46, p. 471-479, Abr. 2016.

ODORISSIO, Renata Maria. Fraseologia em corpus oral e escrito: a linguagem culinária em rede sob a lente da Linguística de Corpus. ReVEL, vol. 15, n. 29 , 2017. 
ORGANIZAÇÃO MUNDIAL DA SAÚDE. Relatório mundial sobre violência e saúde. Genebra: OMS, 2002. 357 p.

Classificação Internacional de Doenças. Genebra: OMS, 2018. Disponível em: <http://icd.who.int>. Acesso em: 01 Set. 2018.

ORTNER, Sherry. Está a mulher para o homem assim como a natureza está para a cultura? In: ROSALDO, Michelle; LAMPHERE, Louise. A Mulher, a cultura, a sociedade. Rio de Janeiro: Paz e Terra, 1979.

PAULA, Douglas Marcos Pereira de et al. A comunicação em saúde como expressão do protagonismo estudantil: a experiência do Gestoresdesaude.com. In: I Seminário Interdisciplinar do curso de Gestão de Serviços de Saúde, 2013, Belo Horizonte. Anais do I Seminário Interdisciplinar do curso de Gestão de Serviços de Saúde, 2013.

PEREIRA, Pedro Paulo. Queer nos trópicos. Contemporânea - Revista de Sociologia da UFSCar, São Carlos, v. 2, n. 2, p. 371-394, Jul-Dez 2012.

PERUCCHI, Juliana; BRANDAO, Brune Coelho; VIEIRA, Hortênsia Isabela dos Santos. Aspectos psicossociais da homofobia intrafamiliar e saúde de jovens lésbicas e gays. Estud. psicol., Natal, v. 19, n. 1, p. 67-76, Mar. 2014.

PINTO, Nuno; MOLEIRO, Carla. As experiências dos cuidados de saúde de pessoas transexuais em Portugal: perspetivas de profissionais de saúde e utentes. Psicologia, Lisboa, v. 26, n. 1, p. 129-151, 2012.

POSSENTI, Sírio. Os humores da língua: análises lingüísticas de piadas. Campinas: Mercado de Letras, 2005. $4^{\mathrm{a}}$ edição.

RESENDE, Livia da Silva. Homofobia e violência contra população LGBT no Brasil: uma revisão narrativa. Monografia (Graduação em Saúde Coletiva) - Universidade de Brasília, 2016, 37 f.

RESENDE, Viviane de Melo. Análise de discurso crítica e etnografia: o Movimento Nacional de Meninos e Meninas de Rua, sua crise e o protagonismo juvenil. Tese (Doutorado em Linguística) - Instituto de Letras / Universidade de Brasília, 2008, $166 \mathrm{f}$. 
RIBEIRO, Rosy. Nac/LGBT comemora um ano de implantação. Polícia Civil de Minas Gerais, 2012. Disponível em:

<https://www.policiacivil.mg.gov.br/noticia/exibir?id=161233>. Acesso em: 19 Mar. 2018.

RAMALHO, Viviane; RESENDE, Viviane de Melo. Análise de discurso (para a) crítica: o texto como material de pesquisa. Campinas: Pontes Editores, 2011.

ROCON, Pablo Cardozo et al. O que esperam pessoas trans do Sistema Único de Saúde? Interface, Botucatu, v. 22, n. 64, p. 43-53, 2018.

ROCHA, Maria José Pereira. Gênero e religião sob a ótica da redescrição. Rev. abordagem gestalt., Goiânia, v. 14, n. 1, p. 102-108, Jun. 2008.

ROCHA, Cássio Bruno Araujo. Um pequeno guia ao pensamento, aos conceitos e à obra de Judith Butler. Cad. Pagu, Campinas, n. 43, p. 507516, Dez. 2014.

ROCHA-BUELVAS, Anderson. El riesgo suicida y los significados de las minorías sexuales: un nuevo reto para la salud pública. Rev. Fac. Med., Bogotá, v. 63, n. 3, p. 537-544, Jul. 2015.

RONDINI, Carina Alexandra; TEIXEIRA FILHO, Fernando Silva; TOLEDO, Lívia Gonsalves. Concepções homofóbicas de estudantes do ensino médio. Psicol. USP, São Paulo, v. 28, n. 1, p. 57-71, Abr. 2017.

RUBIN, Gayle. O tráfico de mulheres: notas sobre a "Economia Política" do sexo. Tradução de Christine Rufino Dabat. Recife: SOS Corpo, 1993 [1975].

SAFATLE, Vladimir Pinheiro. Dos problemas de gênero a uma teoria da despossessão necessária: ética, política e reconhecimento em Judith Butler. Belo Horizonte: Autêntica, 2015. (Posfácio).

SALIH, Sara. Judith Butler e a Teoria Queer. Tradução Guacira Lopes Louro. Belo Horizonte: Ed. Autêntica, 2012. 
SANTOS, Wagner Jorge dos. A religiosidade como estratégia de enfrentamento do processo de incapacidade funcional dos idosos da cidade de Bambuí. Dissertação (Mestrado em Saúde Coletiva) - Instituto René Rachou / Fundação Oswaldo Cruz, 2012. 93 f.

SANTOS, José Vicente Tavares do. A violência simbólica: o Estado e as práticas sociais. Revista Crítica de Ciências Sociais, Coimbra, n. 108, p. 183190, Dez. 2015.

SÃO PAULO. Lei n. 10.948, de 05 de novembro de 2001. Dispõe sobre as penalidades a serem aplicadas à prática de discriminação em razão da orientação sexual e dá outras providências. Disponível em:

$<$ https://www.al.sp.gov.br/repositorio/legislacao/lei/2001/lei-10948-

05.11.2001.html>. Acesso em: 19 Mar. 2018.

SCHRAMM, Fermin Roland. Violencia y práctica ética. Salud Colectiva, v.5, n. 1, p. 13-25, abr. 2009.

SCOTT, Joan. Gênero: uma categoria útil de análise histórica. Educação e Realidade, v. 20, n. 2, p. 71-90, 1995.

SEDGWICK, Eve Kosofsky. A epistemologia do armário. Cad. Pagu, Campinas, n. 28, p. 19-54, jan/jun. 2007.

SEFFNER, Fernando; PARKER, Richard. Desperdício da experiência e precarização da vida: momento político contemporâneo da resposta brasileira à aids. Interface, Botucatu, v. 20, n. 57, p. 293-304, Jun. 2016.

SEVILLA, Gabriela Garcia; SEFFNER, Fernando. Articulações pós-identitárias e pós-gênero: possibilidades e limites de contestação das normas de gênero e sexualidade. In: Fazendo Gênero 10: Desafios atuais dos feminismos. Anais..., Florianópolis, 2013.

SILVA, Ivanilda Tavares de Lima et al. Inovação e Comunicação na Gestão de Serviços de Saúde: a experiência de construção de um website. In: UFMG Conhecimento e Cultura, 2013, Belo Horizonte. Anais do UFMG Conhecimento e Cultura, 2013a. 
. Comunicação em Saúde e protagonismo estudantil: uma experiência digital. In: VI Congresso Brasileiro de Ciências Sociais e Humanas em Saúde, 2013, Rio de Janeiro. Anais do VI Congresso Brasileiro de Ciências Sociais e Humanas em Saúde, 2013. p. 453-454.

SILVA, Cláudia Yaísa Gonçalves da; MILANI, Rute Grossi. Adolescência e tendência antissocial: o rap como expressão de uma privação emocional. Psicol. cienc. prof., Brasília, v. 35, n. 2, p. 374-388, Jun. 2015.

SILVA, Glauber Weder dos Santos et al. Situações de violência contra travestis e transexuais em um município do nordeste brasileiro. Rev. Gaúcha Enferm., Porto Alegre, v. 37, n. 2, e56407, 2016.

SILVA, Lívia Karoline Morais da et al. Uso do nome social no Sistema Único de Saúde: elementos para o debate sobre a assistência prestada a travestis e transexuais. Physis, Rio de Janeiro, v. 27, n. 3, p. 835-846, Jul. 2017.

SILVEIRA, Denise Tolfo; CÓRDOVA, Fernanda Peixoto. A pesquisa científica. In: GERHARDT, Tatiana Engel; SILVEIRA, Denise Tolfo (orgs.). Métodos de pesquisa. Porto Alegre: UFRGS, 2009.

SILVERIO JUNIOR, Renato Cezar. Curtições, amizades e injúrias: as expressões de gênero, sociabilidades, afetos e sexualidades entre garotos adolescentes do interior paulista em uma cidade de pequeno porte. Dissertação (Mestrado em Psicologia) - Universidade Estadual Paulista P1 de Mesquista Filho, 2013. $103 \mathrm{f}$.

SIQUEIRA, Marcus Vinicius Soares et al. Homofobia e violência moral no trabalho no Distrito Federal. Organ. Soc., Salvador, v. 16, n. 50, p. 447-461, Set. 2009.

SOUZA, Érica Renata. Interseções entre homossexualidade, família e violência: relações entre lésbicas na região de Campinas (SP). Soc. e Cult, Goiânia, v. 15, n. 2, p. 297-308, Jul./Dez. 2012. 
SOUZA, Heloisa Aparecida de; BERNARDO, Marcia Hespanhol.

Transexualidade: as consequências do preconceito escolar para a vida profissional. Bagoas, Natal, v. 8, n. 11, p. 157-175, 2014.

TERRA. Bullying homofóbico colabora com evasão escolar, diz Unesco. Caderno Educação, publicado em 07 Nov. 2011. Disponível em:

$<$ https://www.terra.com.br/noticias/educacao/bullying-homofobico-colaboracom-evasao-escolar-diz-

unesco,17b942ba7d2da310VgnCLD200000bbcceb0aRCRD.html>. Acesso em: 14 Mai. 2018.

TOOMEY, Russel B. et al. Coping with sexual orientation-related minority stress. Journal of Homosexuality, v. 65, n. 4, p. 484-500, 2017.

TOLEDO, Lívia Gonsalves; PINAFI, Tânia. A clínica psicológica e o público LGBT. Psicol. clin., Rio de Janeiro, v. 24, n. 1, p. 137-163, 2012.

TOLEDO, Lívia Gonsalves; TEIXEIRA FILHO, Fernando Silva. Homofobia familiar: abrindo o armário 'entre quatro paredes'. Arq. bras. psicol., Rio de Janeiro, v. 65, n. 3, p. 376-391, 2013.

VARTABEDIAN, Julieta. Travestis brasileiras trabalhadoras do sexo - algumas notas além da heteronormatividade. Bagoas, Natal, v. 17, p. 63-92, 2017.

VIEIRA, Marcelo. "Quero poder existir": contornos da violência simbólica contra orientações sexuais não binárias entre universitários LGBT da Universidade Federal de Santa Catarina. Dissertação (Mestrado em Saúde Coletiva) - Universidade Federal de Santa Catarina, Florianópolis, 2015a. 58 f.

VIEIRA, Paula. População negra e a luta diária pelo direito à saúde. Centro de Estudos das Relações de Trabalho e Desigualdades. 2015b. Disponível em: $<$ https://www.ceert.org.br/noticias/saude/7783/populacao-negra-e-a-luta-diariapelo-direito-a-saude>. Acesso em: 21 Mar. 2018. 
VINUTO, Juliana. A amostragem em bola de neve na pesquisa qualitativa: um debate em aberto. Temáticas, Campinas, v. 22, n. 44, p. 203-220, Ago./Dez. 2014

WIEVIORKA, Michel. Violência hoje. Ciênc. Saúde Coletiva, Rio de Janeiro, v. 11, supl. p. 1147-1153, 2006. 


\section{ANEXOS}

9.1 - Roteiro de entrevista semiestruturada

\section{Introdução}

Gostaria de agradecer seu interesse em colaborar com essa pesquisa e reafirmo que sua participação é sigilosa e confidencial.

\section{Parte I - Perfil da (o) participante}

Por qual nome você prefere ser chamado?

Qual sua idade?

Qual sua profissão?

Qual seu grau de escolaridade?

Qual sua cor/raça/etnia?

Qual sua identidade de gênero?

Qual sua orientação sexual?

\section{Parte II - Contextos de violência}

Por favor, me fale as três palavras que vêm à sua mente quando eu falo a palavra violência.

Para você, que é violência?

Você já sofreu violência?

Você deseja contar como foi?

A que você atribui essa violência?

Você atribui essa violência a sua identidade de gênero/orientação sexual?

Você sofreu violência por conta de sua identidade de gênero/orientação sexual?

Você deseja contar como foi? (Caso a (o) participante não aborde alguma violência de gênero/orientação sexual) 


\section{Parte III - Estratégias de enfrentamento}

O que você fez para lidar com essa violência?

Você busca algum apoio quando ocorre esse tipo de situação? Onde?

Você já presenciou algum ato de violência de qualquer tipo contra outra pessoa por conta da identidade de gênero/orientação sexual dela? Como foi?

Você sabe se essa pessoa buscou algum apoio por causa dessa situação?

\section{Encerramento}

Para você, o que são direitos humanos?

Tem algo que você gostaria de falar que ainda não foi abordado até agora? 


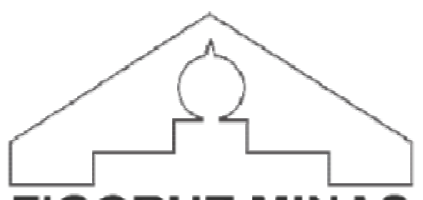

FIOCRUZ MINAS

Centro de Pesquisas René Rachou

FUNDAÇÃO OSWALDO CRUZ CENTRO DE PESQUISAS RENÉ RACHOU BELO HORIZONTE - MG - BRASIL

Termo de Consentimento Livre e Esclarecido

A Senhora/O Senhor está sendo convidada (o) a participar da pesquisa "ESTRATÉGIAS DE ENFRENTAMENTO CONTRA A VIOLÊNCIA PELA COMUNIDADE DE LÉSBICAS, GAYS, BISSEXUAIS, TRAVESTIS E TRANSEXUAIS". Neste estudo pretendemos compreender as estratégias de enfrentamento da violência de gênero e de orientação sexual pela comunidade LGBT.

O motivo que nos leva a estudar esse assunto é a necessidade de entender melhor como pessoas da comunidade LGBT vivem em um contexto de diversas violências como é o exemplo do Brasil. Você foi selecionada (o) por ser membro da comunidade LGBT e ter vivido algum momento de violência por conta de sua identidade de gênero ou orientação sexual e sua participação não é obrigatória.

Para este estudo adotaremos os seguintes procedimentos: entrevista gravada em áudio, em local à sua escolha, transcrição desse áudio, análise $\mathrm{e}$, caso concorde, um novo encontro em local igualmente à sua escolha para discutir sobre essa análise. Seus dados pessoais serão confidenciais e sigilosos. Os áudios serão ouvidos apenas pelo pesquisador principal e pela pesquisadora principal. 
Os riscos de participar desta pesquisa são: constrangimento, reconhecimento e lembranças de momentos desagradáveis. Para minimizar esses riscos serão tomadas as seguintes medidas: não divulgação de qualquer informação que te identifique; atribuição de nomes ou codinomes falsos e, caso queira ou necessite, a pesquisadora principal (psicóloga) pode fazer acolhimento inicial e, se necessário, fazer encaminhamento para a rede de atenção psicossocial do município.

A sua participação neste estudo não lhe trará nenhum benefício direto. Os benefícios são indiretos, pois os resultados desta pesquisa serão partilhados com movimentos sociais, universidades e instituições que defendem os direitos humanos da comunidade LGBT, porém não serão divulgados quaisquer dados que possam te identificar. Em caso de qualquer dano decorrente diretamente da sua participação neste estudo, você terá direito a indenização.

Para participar deste estudo você não terá nenhum custo, pois os pesquisadores irão até você e nem receberá qualquer vantagem financeira. Você será esclarecida (o) sobre o estudo em qualquer aspecto que desejar e estará livre para participar ou recusar-se a participar. Poderá retirar seu consentimento ou interromper a participação a qualquer momento. A sua participação é voluntária e a recusa em participar não acarretará qualquer penalidade.

Os resultados da pesquisa estarão à sua disposição quando finalizada, em formato que facilite seu acesso.

Este termo de consentimento será assinado em duas vias, sendo que uma delas será arquivada pelo pesquisador responsável, no Centro de Pesquisa René Rachou/Fundação Oswaldo Cruz e a outra será fornecida a você.

A qualquer momento você poderá solicitar informações sobre sua participação elou sobre a pesquisa, o que poderá ser feito através dos contatos fornecidos abaixo. Em caso de dúvida quanto à condução ética do estudo, entre em contato com o Comitê de Ética em Pesquisa do CPqRR, órgão responsável por defender os interesses dos participantes da pesquisa.

Pesquisadora Principal: Celina Maria Modena Endereço: Avenida Augusto de Lima, 1.715 - Barro Preto CEP: 30.190-002 - Belo Horizonte - MG 
Fone: (31) 3349 - 7882

E-mail: celina@cpqrr.fiocruz.br

Comitê de Ética em Pesquisa Centro de Pesquisas René Rachou da Fundação Oswaldo Cruz

Endereço: Avenida Augusto de Lima, 1.715 - Barro Preto

CEP: 30.190-002 - Belo Horizonte - MG

Fone: (31) 3349 - 7825

E-mail: cepsh-cpqrr@cpqrr.fiocruz.br

Eu,

, fui informada (o) dos objetivos do estudo de maneira clara e detalhada e esclareci minhas dúvidas. Sei que a qualquer momento poderei solicitar novas informações e modificar minha decisão de participar se assim 0 desejar. Declaro que concordo em participar desse estudo. Recebi uma via deste termo de consentimento livre e esclarecido e me foi dada a oportunidade de ler e esclarecer as minhas dúvidas.

Belo Horizonte, de de2017.

Assinatura da (o) participante

Assinatura da (o) pesquisador(a) 
9.3 Artigo de revisão sobre estratégias de enfrentamento, submetido ao Journal of Homosexuality.

Coping strategies as performativity of lesbian, gay, bisexual, transgender, intersex, and other identities in the face of violence based on gender and/or sexual orientation

\begin{abstract}
This paper aims at identifying and analyzing coping strategies against sexual orientation and gender-based violence developed by the LGBTI+ community and described in the scientific literature. The articles were searched in the BVS, SciELO and PubMed databases and the inclusion criteria were articles published between 2008 and 2017 written in Spanish, English or Portuguese and describing coping strategies developed by people who identified themselves as LGBTI+. The results showed that the main way to deal with violence is by seeking support from friends, family, religion, other LGBTI + people and specialized services. Hiding the LGBTI + identity is the second most described. It is concluded that these strategies can be understood not only as responses to stressful external factors but also as performative acts that constitute the LGBTI+ subject as they are constructed.
\end{abstract}

Keywords: Violence, coping strategies, sexual minorities, performativity, LGBTI+

\title{
Introduction
}

'Coping strategies' is a polysemic term and its use differs according to the theoric-conceptual base used. For social studies, those are ways that social orders adapt to a crisis situation. In biology, coping strategies can be considered as ways that the organism adapts to environmental conditions (Nunes, 2010). In the scientific literature of the field of Psychology, strongly present in the cognitive-behavioural line, the concept appears with Lipowski 
(1970), meaning cognitive and motor actions that a person with disease used to preserve oneself. White (1974) brings coping strategies as adaptations to drastic conditions, which promote a state of restlessness, imbalance, discomfort in a person. In the same decade, Weisman and Worden (1976) define the concept from its objective: the search for relief, tranquillity and gratification. Mechanic (1976) points out that coping strategies are skills, knowledge and techniques that are used to solve problems of the individual. The most used conceptual model is the one by Lazarus and Folkman (1984), which determines coping strategies as actions and strategies of cognitive and behavioral order in front of stressful situations, alternating between two groups, according to the function: strategies focused on the problem, when they objectify the decrease or elimination of the stressor source, for example, triggering a network of friends for manifestation; or the emotion, when efforts are made to reduce sensations arising from the object that is being faced, such as tingling, tachycardia and sweating (Lazarus 1984; Nunes 2010). Contemporary to these authors, Yeatts and Lochbaum (2013) also subcategorize coping strategies. There are, therefore, coping styles and coping strategies per se. The former corresponds to the way in which the individual usually deals with stress, while the latter are specific ways of dealing with delimited situations. Strategies would thus be dependent on the coping style of the person.

In this article we will try to understand the coping strategies by a poststructuralist lens, understanding them as performativity (Butler, 2003). In this way, coping strategies are neither outside nor within the individual but are constituted by the subjects, while also constitute them. The focus of strategies is, therefore, the enunciative scene in which the supposedly external problem or the emotions allegedly internal to the individual occur and no longer occur. In this way, language is the means by which strategies will be constituted, collaborating equally for the performance of gender, since it is constructed by iterated acts and gestures (Batista, 2007). The performance rendering of strategies does not end in the performance itself, that is, in the execution of the coping strategy - in fact, performativity is a global process of construction of subjects, crossed by linguistic-semiotic actions present in social relations. Thus, 
coping strategies are located both in the quotidian of relationships and in the ontological constitution of those who participate in them (Butler, 2003; Mingo \& Moreno, 2017). The epistemological choice of this scientific lens is due to the fact that we will investigate the coping strategies constructed by the community of lesbians, gays, bisexuals, travestis, transsexuals and other identities (LGBTI+) in the face of sexual orientation and/or gender-based violence. Such population group advocates for the transitivity, complexity, disruption and fluidity of categories imputed to bodies. The imposition of cis heteronormativity is deconstructed by post-structuralist perspectives, which are rejected to assert the precariousness and temporality of society (Butler, 2015a, 2015b). To seek the understanding of the coping strategies of this population as performativity is to undertake coherence with the demands of the LGBTI+ community and to broaden the understanding of the relationships in which they are constituted.

In reference to the relationship between coping strategies and gender identity I sexual orientation, research has shown that people belonging to sexual minorities trigger more strategies because they are under more pressure and social stress (Meyer, 2013; McEwen, 2015; Alamo, 2017). Most of the published literature review work found on coping strategies and the LGBTI+ community use the behavioural lens to understand the object of study. The innovation of this article is to seek other perspectives on the problem in order to contribute to the knowledge base about the LGBTI+ community and to base interventions to guarantee human rights to this population.

Therefore, the objective of this article is to identify and analyze the strategies of coping with violence towards gender and/or sexual orientation developed by the LGBTI + community.

\section{Methodology}

An integrative literature review was carried out, understood as the broad search of scientific works, including those experimental and non-experimental in order to understand the object of research as completely as possible. Such a vast 
intended panorama should be equally consistent and comprehensive of complex phenomena and concepts (Souza et al., 2010).

The databases of Biblioteca Virtual em Saúde (BVS/Bireme), the National Library of Medicine (PubMed) and the Scientific Electronic Library Online (SciELO) were used for this review. The descriptors used were 'coping strategies' (BVS and SciELO) or 'coping' (PubMed) and their combinations with 'sexual minorities', 'homosexuality', 'transgender people', 'gender identity', 'gender and health' and 'sexism'. The choice of terms for research was based on queries made to the Health Sciences Descriptors portal (DeCS) and Medical Subject Headings $(\mathrm{MeSH})$, being considered the closest to the research question. The terms 'coping strategy' and 'coping' are considered synonymous by $\mathrm{DeCS}$ and $\mathrm{MeSH}$, respectively, using the root term 'psychological adaptation'. However, this term is little used in studies on the LGBTI + community, and synonyms were chosen in order to gather more work

The inclusion criteria were: I) articles published from 2008 to 2017, in order to verify the state of the art in the last ten full years; II) works in Portuguese, English or Spanish, III) title and summary consistent with the research question. Quantitative and/or qualitative methodologies were used to quantify the results of researches with the LGBTI + population and to specify which strategies the people participating in the research used in relation to any type of violence due to gender or sexual orientation. Therefore, exclusively theoretical-conceptual articles were excluded, as were equal articles found in different search strategies and/or databases.

The search for scientific productions was graphically constructed according to figure 1 . The values of figure 1 refer to the sum of the results found from the combination of descriptors in each database used. 


\section{Results}

Table 1 shows the articles found and some of their characteristics. The majority of articles selected were published in 2015 (27.6\%) or in 2016 (17.9\%), using qualitative methodological pathways $(53.4 \%)$ and carried out in the United States $(51.7 \%)$. There is an increase in the number of publications from 2015 to 2017, corresponding to $58.6 \%$ of the articles found in the search. Regarding the geographic matter, the continent of the Americas was responsible for $62.1 \%$ of the published researches, an expected result due to the databases used and Latin languages as the inclusion criterion. There was only one article that used mixed research methodology (McDermott, Hughes \& Rawlings, 2017).

Several subgroups of the LGBTI + community were surveyed, the most present being: transgender people (13.8\%), men who have sex with other men (MSM) (12.1\%), lesbians (12.1\%) and lesbians, gays and bisexuals (11.1\%). Other framings appeared in articles alone, such as homoaffective people (Santos \& Fernandes, 2009), intersex (Mackenzie, Huntington \& Gilmour, 2009), gay, bisexual and trans (GBT) (Martin \& Alessi, 2010), lesbian, gay, bisexual and questioning (LGBQ) (Sornberg et al., 2013), lesbian and bisexual women (LB) (Mason \& Lewis, 2015), men who have sex with other men and trans women (Andrinopoulos \& Hembling, 2015), gay men and trans women (Rowe et al., 2015), two-spirited people (Elm et al., 2016), men from sexual minorities and trans women (Bry et al., 2017), lesbian, gay, bisexual, transgender and queer (LGBTQ) (Mcdermott, Hughes \& Rawlings, 2017) and lesbian, gay, bisexual, transgender, queer and othersexual and gender minorities (LGBTQ+) (Eliason, Streed \& Henne 2017). It is possible to perceive that such denominations are more used in recent productions, indicating recognition of identities and intragroup differences significant enough to influence the research agenda in the LGBTI+ field.

The selected papers brought several coping strategies developed by the people participating in the research. Due to the amount found, it was decided to put together similar strategies in groups, according to table 2 . 
It is noticed that the search for social support, which brought together strategies that include support from friends, other LGBTI + people, family, spouse, religion and specialized services, is the most recurrent, followed by concealment of identity, whether from all people or from not so close people as co-workers, or in public places. Thirdly, the use of alcohol and other drugs, whether or not they are linked to sexual relations, and social isolation - strategies described as not leaving home, avoiding physical or visual contact, not attending public leisure environments, among others were inserted in this group. As resilient thoughts were joined strategies that figured as positive thinking after an act of violence, ignoring the aggressor, seeking reflections of self-esteem and appreciation of the self, etc. Searching for bars, nightclubs, squares and other public environments was a strategy reported nine times in the selected articles. Alongside the group 'Verbal or physical confrontation of the aggressor', there are strategies that involved self-mutilation, fasting, putting oneself in risky situations and having unprotected sex; those were under the name 'Selfdestructive behaviour'. Almost diametrically to the strategy of hiding, is the exit of the closet, the affirmation of the LGBTI+ identity, strategies gathered in the group 'Assuming the identity of gender or of sexual orientation', whose frequency was of seven times in the articles. The ideations and attempts of suicide due to gender violence and sexual orientation are in the antepenultimate place, right after strategies that aim to dialogue with and educate perpetrators of violence and others who are unaware of the subject. At last, there is activism, which consists of the entry on social movements by LGBTI+ people.

\section{Discussion}

We start from Butler's conceptual construct of gender performativity to shed light on coping strategies as acts and iterated practices that constitute the subject and are not only responses to external stimuli. According to the author,

(...) acts, gestures, and desire produce the effect of a nucleus or internal substance but produce it on the surface of the body through the play of significant absences, which suggest, but never reveal, the organizing principle of identity as a cause. These acts, 
gestures and performances, understood in general terms, are performative, in the sense that the essence or identity they otherwise intend to express is a fabrication manufactured and sustained by corporeal signs and other discursive means. The fact that the body is marked by the performative suggests that it has no separate ontological status (Butler, 2003, 194).

One of the most present strategies for coping with violence was the concealment of sexual and/or gender identity (25.9\%). The decision not to say about oneself is present in all subgroups of the LGBTI + community: lesbians, gays, men who have sex with other men, trans people, bisexuals and sexual minorities, with intragroup differences only with regard to motives reported in the surveys. As an example, in Hamdi, Lachheb and Anderson (2015), women conceal their identity for fear of a very traditionalist Tunisian culture, whereas Losert (2008) points out that concealment is due to the fear of losing a job or having to face an unbearable work environment. Goldbach and Gibbs (2016) bring this strategy as a mediator between the LGBTI+ person and the prejudiced family, a similar finding in the work on gay cis men in Itzhaky and Kissil (2015).

These and other works demonstrate that the subject modifies his / her corporeity as the context changes. Such change is repeated as many times as necessary, becoming natural, crystallizing into the essence of the subject (Butler, 2003; Mingo \& Moreno, 2017). Thus, trying to pass by someone who is heterosexual ceases to be a response to external stimulus or a way of temporarily surviving the stressor element and begins to constitute the LGBTI+ subject, there being nothing behind it but the person in relation to another. Hence, the idea that being perceived as a political-sexual minority is having to avoid such perception, since constant discrimination leads the subject to heteronormalized performances on a daily basis, imputing this effect of substance to the surface of the body. This 'option' to conceal itself is not created by the subject, but already established in the discursive practices of the surrounding society, so it is not any parody of a heterosexual person that the 
LGBTI+ subject will perform, but rather the one that is most accepted by the enunciative scene that it is relating to. Parody because, from Butler (2003), it is understood that identities are collections of meanings received culturally or personally that, together with other sets, construct the illusion of a primary identity, but which, in fact, has no origin. When one seeks to be or to go by heterosexual, one tries to mould himself into something anterior to it, imitating this original idea of identity, parodying it. However, this heterosexual essence does not exist - it is historically and socially constructed.

Other papers selected point to the opposite of concealing: McDermott, Roen and Scourfield (2008), Hequembourg and Brailler (2009), Monteiro, Machado and Nardi (2011), Pelúcio (2011), Bjorkman and Malterud (2012), Erhard and Bem-Ami (2015) and Bry et al. (2017) bring stories of affirmation of identity towards violent situations motivated by prejudice. This strategy is inserted in the bulge of performances because it also constitutes the subject in the scene as it is constituted by it. Butler (2003) states that even the alleged transformations or rebellions can only happen in an intelligible field, formed by preexisting discursive practices. In affirming themselves as LGBTI+, the subjects do it by a certain language and in certain relationships. Eliason et al. (2017), for example, points out that LGBTI+ health professionals educate patients and clients through a friendly and reassuring dialogue on the matter, as well as in the work of Bowleg et al. (2008), there is the confrontational education of co-workers by non-heterosexual women. Here the LGBTI+ person is constituted as such as it repeats, in different scenes, the same coping strategy, explaining to its interlocutors its physical and discursively political body. Sustaining the place of LGBTI+ (Monteiro, Machado, \& Nardi, 2012) is thus affirming oneself in the violent enunciative scene with agency, with the possibility of change, although constrained by what has already been instituted.

Another issue necessary to the debate of coping strategies as performativity is its temporal and collective character and not merely individual manifestation. 
Some studies point to the use of substances to deal with the violent and stigmatizing situation (Mcdermott, Roen \& Scourfield, 2008; Hequembourg \& Brailler, 2009; Wagner et al., 2013; Mereish, O'Cleirigh \& Bradford, 2014; Ha et al.; 2015; Reisner et al., 2015; Freeland, Goldenberg \& Stephenson, 2016; Rood et al., 2016; Rowe et al., 2016; Boyle et al., 2017). The drugs used by the subjects due to the violence suffered by them are not pre-existing as such (Reed, 2013). Be it alcohol, tobacco, or any other substance, it only becomes drug by the practices of use in well-defined contexts. Marijuana, for example, can be orchestrated by biomedical or religious discursive practices, and such a decision will vary by the hegemonically related ideology in the scene. By using these artefacts, the LGBTI+ seeks elements of exteriority to be constituted here, the constituting happens both by significant correlates to drugs that cross the subject and by the biochemical incorporation of the substance in its body, modifying it or sustaining it, depending on the relationships built there. This interpolation of the subject by the discursive-material apparatus of drugs may be related, as shown by Rowe et al., (2015), to sex, constituting multiple ways of dealing with sexual orientation and gender-based violence.

Whether through addiction or occasional use, repetition of the act of using drugs is not limited to practice itself, reaching the level of language, where the silencing of non-hegemonic identities intertwines with drug silencing - one cannot speak about all drugs at all places, just as sometimes one cannot be LGBTI+ depending on the place or situation (Hequembourg \& Brailler, 2009; Reed, 2013; Difulvio, 2015; Rood et al., 2016). Therefore, metaphors, gestures, looks, nicknames and scientific names are used to euphemize the subject. Such discursive practices constitute the LGBTI+ subject as it performs this strategy, being its body the sum of artefacts and ideologies, crossed by the relations with the other or affirmed by the self in scene.

The coping strategies most described in the articles were the search for social support in the face of violence. This need for the encounter with the other reveals the precariousness of the lives that unite for alliances against hegemonic discursive structures (Butler, 2009). Even if devices such as family 
and religion may not be strongly inserted in this counter-hegemonic discursive practice, they appear as formators of other orders, since they welcome and protect LGBTI+ people victims of violence. In this way they also affirm their precariousness, their impossibility of discursive self-sufficiency, being selfsufficient or magnanimous - they need the other, in this case, non-cis heterosexual victimized people, to constitute themselves and this other as family, religion, friends, etc. When this relationship of mutual need of the other in itself does not happen, the search for support results in possibilities of extermination of the LGBTI+ person. For example, Itzhaky and Kissil (2015) point out that the search for religion occurs with the objective of participating in rituals of 'purification' of homosexuality. It is perceived that religion is individuating, sufficient in its ethos, which imposes on its followers to assume certain values and behaviours and it does so by a performance whose responsibility impute to a non-terrain being, therefore unattainable, leaving, at last, the subjugation of the LGBTI+ person.

As a conclusion, the objective was to identify and analyze strategies for coping with sexual orientation and/or gender-based violence developed by the LGBTI+ community and, through an integrative literature review, it was possible to bring together various forms of dealing with dialectically constituted violence. It was sought to advance in the analyzes of Butler's poststructuralist pathways understanding coping strategies in addition to an equilibrium-perturbationresponse-equilibrium system, with a behaviouralist and cognitive bias.

Dealing with sexual orientation or gender-based violence refer to actions repeated and naturalized by the LGBTI+ community due to their recurrence. In Brazil, for example, a death is reported every 19 hours (GGB, 2018), and most victims are cis gay men and transvestites. This context challenges the subject in the sense of it being constituted by the support of friends, use of substances, concealing/affirming of identity and other interdiscursivities to be (or not) LGBTI+. 
The choice of the banks of scientific articles, more used by scientists of American or European origins, the restriction to three languages and the noninclusion of theses and dissertations are limiting factors of the research since they may have excluded contributions from African and Asian authors, as well as from other regions of the globe.

Future research and interventions can undertake new understanding of coping strategies constituted in different biographical times, such as Toomey et al. (2017) did with young lesbians, gay men and bisexual people about the time of their teens.

Do the strategies change throughout life or does the iteration of these acts change relationships without actually transforming? Methodological, as well as cohort studies, may help in this investigative path. It is hoped, therefore, that this revision can subsidize other practices, more LGBTI + affirmative, in scenes of violence.

Declaration of interest statement: There is no conflict of interests.

\section{References}

Alamo, J. (2017). A phenomenological study: coping asills of gay men in amateur sports. PhD diss., Walden University.

Arístegui, I., Radusky, P., Zalazar, V., Lucas, M. \& Sued, O. (2017). Resources to cope with stigma related to HIV status, gender identity, and sexual orientation in gay men and transgender women. Journal of Health Psychology, 23(2): 320331.

doi:

$10.1177 / 135910531773$

6782.

Bariola, E., Lyons, A., Leonard, W., Pitts, M., Badcock, P. \& Couch, M. (2015). "Demographic and Psychosocial Factors Associated With Psychological Distress and Resilience Among Transgender Individuals." American Journal Of 
Public Health, 105(10): 2108-2116. doi: 10.2105/ajph.2015.302763.

Barrett, C., Crameri, P., Lambourne, S., Latham, J. \& Whyte, C. (2015). Understanding the experiences and needs of lesbian, gay, bisexual and trans Australians living with dementia, and their partners. Australasian Journal on Ageing, $\quad 34: \quad 34-38$ doi: $10.1111 /$ ajag. 12271.

Batista, K. (2007). Judith Butler, a performance e a psicanálise: um estudo epistemológico. MSc. diss., Universidade Católica de Brasília.

Bjorkman, M. \& Malterud, K. (2012). Lesbian women coping with challenges of minority stress: A qualitative study. Scandinavian Journal of Public Health, 40(3): $\quad 239-244 . \quad$ doi: $10.1177 / 1403494812443608$.

Bogart, L., Dale, S., Christian, J., Patel, K., Daffin, G., Mayer, K. \& Pantalone, D. (2016). Coping with discrimination among HIV-positive Black men who have sex with men. Culture, Health and Sexuality, 19(7): 723-737. doi: 10.1080/13691058.2016.1258492.

Boyle, S., LaBrie, J., Costine, L. \& Witkovic, Y. (2017). It's how we deal: Perceptions of LGB peers use of alcohol and other drugs to cope and sexual minority adults own coping motivated substance use following the Pulse nightclub shooting. Addictive Behaviors, 65: 51-55. doi: 10.1016/j.addbeh.2016.10.001.

Bry, L., Mustanski, B., Garofalo, R. \& Burns, M. (2017). Resilience to discrimination and rejection among young sexual minority males and transgender females: a qualitative study on coping with minority stress. Journal of Homosexuality, 1-22. doi: 10.1080/00918369.2017.1375367.

Budge, S., Adelson, J. \& Howard, K. (2013). Anxiety and depression in transgender individuals: The roles of transition status, loss, social support, and coping. Journal of Consulting and Clinical Psychology, 81(3): 545-557. doi: 
10.1037/a0031774.

Butler, J. (2003). Problemas de Gênero: Feminismo e Subversão da Identidade. Rio de Janeiro: Civilização Brasileira.

Butler, J. (2009). Vida precaria: el poder del duelo y la violência. Buenos Aires: Paidós.

Butler, J. (2015). Quadros de Guerra: quando a vida é passível de luto. Rio de Janeiro: Civilização Brasileira.

Butler, J. (2015b). Relatar a si mesmo: crítica da violência ética. Belo Horizonte: Autêntica.

Choi, K., Han, C., Paul, J. \& Ayala, G. (2011). Strategies for managing racism and homophobia among u.s. ethnic and racial minority men who have sex with men. AIDS Education And Prevention, 23(2): 145-158. doi: 10.1521/aeap.2011.23.2.145.

Choi, K., Steward, W., Miège, P., Hudes, E. \& Gregorich, S. (2015). Sexual stigma, coping styles, and psychological distress: a longitudinal study of men who have sex with men in Beijing, China. Archives Of Sexual Behavior, 45(6): 1483-1491. doi: 10.1007/s10508-015-0640-z.

D'haese, L., Dewaele, A. \& Van Houtte, M. (2015). Coping with antigay violence: in-depth interviews with Flemish LGB adults. The Journal of Sex Research, 52(8): 912-923. doi: 10.1080/00224499.2014.990554.

DiFulvio, G. (2014). Experiencing violence and enacting resilience. Violence Against Women, 21(11): 1385-1405. doi: 10.1177/1077801214545022.

Eliason, M., Streed, C. \& Henne, M. (2017). Coping with stress as an LGBTQ+ health care professional. Journal of Homosexuality, 65(5): 561-578. doi: 
10.1080/00918369.2017.1328224.

Elm, J., Lewis, J., Walters, K. \& Self, J. (2016). I'm in this world for a reason: Resilience and recovery among American Indian and Alaska Native two-spirit women. Journal of Lesbian Studies, 20(3-4): 352-371. doi: 10.1080/10894160.2016.1152813.

Ephrem, B. \& White, A. (2011). Agency and expression despite repression: a comparative study of five Ethiopian lesbians. Journal of Lesbian Studies, 15(2): 226-246. doi: $10.1080 / 10894160.2011 .527765$.

Erhard, R. \& Ben-Ami, E. (2015). The schooling experience of lesbian, gay, and bisexual youth in Israel: falling below and rising above as a matter of social ecology. Journal of Homosexuality, 63(2): 193-227. doi: 10.1080/00918369.2015.1083778.

Freeland, R., Goldenberg, T. \& Stephenson, R. (2016). Perceptions of informal and formal coping strategies for intimate partner violence among gay and bisexual men. American Journal of Men's Health, 12(2): 302-312. doi: 10.1177/1557988316631965.

Ganju, D. \& Saggurti, N. (2017). Stigma, violence and HIV vulnerability among transgender persons in sex work in Maharashtra, India. Culture, Health and Sexuality, 19(8): 903-917. doi: 10.1080/13691058.2016.1271141.

Gilbert, P., Barrington, C., Rhodes, S. \& Eng, E. (2016). Saliendo Adelante. American Journal of Men's Health, 10(6): 515-525. doi: $10.1177 / 1557988316647704$.

Ha, H., Risser, J., Ross, M., Huynh, N. \& Nguyen, H. (2015). Homosexualityrelated stigma and sexual risk behaviors among men who have sex with men in Hanoi, Vietnam. Archives of Sexual Behavior, 44(2): 349-356. doi: 10.1007/s10508-014-0450-8. 
Hamdi, N., Lachheb, M. \& Anderson, E. (2015). Queen of Fights: lesbians in Tunisian sports. Journal of Homosexuality, 63(8): 1127-1145. doi: 10.1080/00918369.2015.1117902.

Hequembourg, A. \& Brallier, S. (2009). An exploration of sexual minority stress across the lines of gender and sexual identity. Journal of Homosexuality, 56(3): 273-298. doi:

$10.1080 / 00918360902728517$.

Itzhaky, H. \& Kissil, K. (2015). It's a horrible sin. If they find out, I will not be able to stay: orthodox jewish gay men's experiences living in secrecy. Journal of Homosexuality, 62(5): 621-643. doi: 10.1080/00918369.2014.988532.

Lazarus, R. (1984). Puzzles in the study of daily hassles. Journal of Behavioral Medicine, $\quad 7(4)$ : $\quad 375-389$. doi: $\quad 10.1007 /$ bf00845271.

Lazarus, R. S. \& Folkman, S. (1984). Coping and adaptation. Chap 5 in The handbook of behavioral medicine, edited by W. D. Gentry, 282-325). New York, NY:

Guilford.

Leaper, C. \& Arias, D. (2011). College women's feminist identity: a multidimensional analysis with implications for coping with sexism. Sex Roles, 64(7-8): $\quad 475-490 . \quad$ doi: 10.1007/s11199-011-9936-1.

Lipowski, Z. (1970). Physical illness, the individual and the coping processes. Psychiatry in Medicine, 1(2): 91-102. doi: 10.2190/19q3-9q|8-xyv1-8xc2.

Losert, A. (2008). Coping with workplace heteronormativity among lesbian employees. Journal of Lesbian Studies, 12(1): 47-58. doi: 10.1300/10894160802174300.

Mackenzie, D., Huntington, A. \& Gilmour, J. (2009). The experiences of people with an intersex condition: a journey from silence to voice. Journal of Clinical Nursing, $\quad 18(12)$ : 1775-1783. doi: 10.1111/j.1365-2702.2008.02710.x. 
Marshall, A., Yarber, W., Sherwood-Laughlin, C., Gray, M. \& Estell, D. (2015). Coping and survival skills: the role school personnel play regarding support for bullied sexual minority-oriented youth. Journal of School Health, 85(5): 334-340. doi:

10.1111/josh.12254.

Martin, J. \& Alessi, E. (2010). Stressful events, avoidance coping, and unprotected anal sex among gay and bisexual men. American Journal of Orthopsychiatry, $80(3)$ : 293-301. doi: 10.1111/j.1939-0025.2010.01032.x.

Mason, T. \& Lewis, R. (2015). Minority stress and binge eating among lesbian and bisexual women. Journal of Homosexuality, 62(7): 971-992. doi: 10.1080/00918369.2015.1008285.

Matsumoto, Y., Sato, T., Ohnishi, M., Kishimoto, Y., Terada, S. \& Kuroda, S. (2009). Stress-coping strategies of patients with gender identity disorder. Psychiatry and Clinical Neurosciences, 63(6): 715-720. doi: 10.1111/j.14401819.2009.02017.x.

McDermott, E., Roen, K. \& Scourfield, J. (2008). Avoiding shame: young LGBT people, homophobia and self-destructive behaviours. Culture, Health and Sexuality, 10(8): $\quad 815-829$. doi: 10.1080/13691050802380974.

McDermott, E., Hughes, E. \& Rawlings, V. (2017). Norms and normalisation: understanding lesbian, gay, bisexual, transgender and queer youth, suicidality and help-seeking. Culture, Health and Sexuality, 20(2): 156-172. doi: 10.1080/13691058.2017.1335435.

McEwen, B. S. (2015). Biomarkers for assessing population and individual health and disease related to stress and adaptation. Metabolism, 64 (Supplement 1), S2-S10.

Mechanic, D. (1976). Stress, illness, and illness behavior. Journal of Human Stress, 2(2): 2-6. doi: 10.1080/0097840x.1976.9936061. 
Mereish, E., O'Cleirigh, C. \& Bradford, J. (2013). Interrelationships between LGBT-based victimization, suicide, and substance use problems in a diverse sample of sexual and gender minorities. Psychology, Health and Medicine, 19(1): $\quad 1-13 . \quad$ doi: $\quad 10.1080 / 13548506.2013 .780129$.

Meyer, I. H. (2013). Prejudice, social stress, and mental health in lesbian, gay, and bisexual populations: Conceptual issues and research evidence. Psychology of Sexual Orientation and Gender Diversity, 1(S): 3-26.

Meyer, I., Schwartz, S. \& Frost, D. (2008). Social patterning of stress and coping: Does disadvantaged social statuses confer more stress and fewer coping resources?. Social Science and Medicine, 67(3): 368-379. doi: 10.1016/j.socscimed.2008.03.012.

Mingo, A. \& Moreno, H. (2017). Sexismo en la universidad. Estudios Sociológicos de el Colegio de México, 35(105). doi: 10.24201/es.2017v35n105.1434.

Monteiro, L., Machado, P. \& Nardi, H. (2011). Do armário à armadura: estratégias de mulheres no enfrentamento da homofobia e do heterossexismo. Polis e Psique, 1(3): 112-139.

Nunes, C. (2010). O conceito de enfrentamento e sua relevância na prática da psiconcologia. Encontro: Revista de Psicologia, 13(9): 91-102.

Peacock, E., Andrinopoulos, K. \& Hembling, J. (2015). Binge drinking among men who have sex with men and transgender women in San Salvador: correlates and sexual health implications. Journal of Urban Health, 92(4): 701716. doi: 10.1007/s11524-014-9930-3.

Pelúcio, L. (2011). Marcadores sociais da diferença nas experiências travestis de enfrentamento à aids. Saúde e Sociedade, 20(1): 76-85. doi: 10.1590/s0104-12902011000100010. 
Pendragon, D. (2010). Coping behaviors among sexual minority female youth. Journal of Lesbian Studies, 14(1): 5-15. doi: 10.1080/10894160903058840.

Reed, S. \& Valenti, M. (2012). It ain't all as bad as it may seem: young black lesbians' responses to sexual prejudice. Journal of Homosexuality, 59(5): 703720. doi: 10.1080/00918369.2012.673940.

Reisner, S., Pardo, S., Gamarel, K., Hughto, J., Pardee, D. \& Keo-Meier, C. (2015). Substance use to cope with stigma in healthcare among U.S. female-tomale trans masculine adults. LGBT Health, 2(4): 324-332. doi: 10.1089/lgbt.2015.0001.

Riley, T., Kirsch, A., Shapiro, J. \& Conley, C. (2016). Examining stress and coping as a mediator for internalizing symptomatology: A comparison between sexual minority and majority first-year college students. Journal of Adolescence, 49: $\quad 124-133 . \quad$ doi: $10.1016 /$ j.adolescence.2016.03.005.

Rood, B., Reisner, S., Surace, F., Puckett, J., Maroney, M. \& Pantalone, D. (2016). Expecting rejection: understanding the minority stress experiences of transgender and gender-nonconforming individuals. Transgender Health, 1(1): 151-164. doi: 10.1089/trgh.2016.0012.

Rowe, C., Santos, G., McFarland, W. \& Wilson, E. (2015). Prevalence and correlates of substance use among trans-female youth ages 16-24 years in the San Francisco Bay Area. Drug and Alcohol Dependence, 147: 160-166. doi: 10.1016/j.drugalcdep.2014.11.023.

Santos, A. \& Fernandes, S. (2010). Enfrentamento, locus de controle e preconceito: um estudo com pessoas de orientação sexual homoafetiva. Psicologia em Revista, 15(03). doi: 10.5752/p.1678-9563.2009v15n3p101.

Sattler, F., Wagner, U. \& Christiansen, H. (2016). Effects of minority stress, group-level coping, and social support on mental health of German gay men. 
PLOS ONE, 11(3): e0150562. doi: 10.1371/journal.pone.0150562.

Scourfield, J., Roen, K. \& McDermott, L. (2008). Lesbian, gay, bisexual and transgender young people's experiences of distress: resilience, ambivalence and self-destructive behaviour. Health and Social Care in the Community, 16(3): 329-336. doi: 10.1111/j.1365-2524.2008.00769.x.

Shilo, G., Yossef, I. \& Savaya, R. (2015). Religious coping strategies and mental health among religious jewish gay and bisexual men. Archives of Sexual Behavior, 45(6): 1551-1561. doi: 10.1007/s10508-015-0567-4.

Shires, D. \& Jaffee, K. (2015). Structural discrimination is associated with smoking status among a national sample of transgender individuals. Nicotine and Tobacco Research, 18(6): 1502-1508. doi: 10.1093/ntr/ntv221.

Sornberger, M., Smith, N., Toste, J. \& Heath, N. (2013). Nonsuicidal self-injury, coping strategies, and sexual orientation. Journal of Clinical Psychology, 69(6): 571-583. doi: 10.1002/jclp.21947.

Souza, M., Silva, M. \& Carvalho, R. (2010). Revisão integrativa: o que é e como fazer. Einstein, 8(1): 102-106.

Toomey, R., Ryan, C., Diaz, R. \& Russell, S. (2017). Coping with sexual orientation-related minority stress. Journal of Homosexuality, 65(4); 484-500. doi:

$10.1080 / 00918369.2017 .1321888$.

Wagner, G., Aunon, F., Kaplan, R., Karam, R., Khouri, D., Tohme, J. \& Mokhbat, J. (2013). Sexual stigma, psychological well-being and social engagement among men who have sex with men in Beirut, Lebanon. Culture, Health and Sexuality, 15(5): 570-582. doi: 10.1080/13691058.2013.775345.

Wang, Y. (2011). Voices from the margin: a case study of a rural lesbian's experience with woman-to-woman sexual violence. Journal of Lesbian Studies, 
15(2):

$166-175$.

doi:

10.1080/10894160.2011.521099.

Wang, J., Plöderl, M., Häusermann, M. \& Weiss, M. (2015). Understanding suicide attempts among gay men from their self-perceived causes. The Journal of Nervous and Mental Disease, 203(7): 499-506. doi: 10.1097/nmd.0000000000000319.

Weisman, A. \& Worden, J. (1977). The existential plight in cancer: significance of the first 100 days. The International Journal of Psychiatry in Medicine, 7(1): 1-15. doi: 10.2190/uq2g-ugv1-3ppc-6387.

White, R. (1974). Strategies of adaptation: an attempt of systematic description. Chap. 8 in Stress and coping: an anthology, edited by A. Monat and R. Lazarus, 121-143. New York: Columbia University Press.

Wilson, P., Meyer, I., Antebi-Gruszka, N., Boone, M., Cook, S. \& Cherenack, E. (2016). Profiles of resilience and psychosocial outcomes among young black gay and bisexual men. American Journal of Community Psychology, 57(1-2): 144-157. doi: 10.1002/ajcp.12018.

Wray, T., Pantalone, D., Kahler, C., Monti, P. \& Mayer, K. (2016). The role of discrimination in alcohol-related problems in samples of heavy drinking HIVnegative and positive men who have sex with men (MSM). Drug and Alcohol Dependence, 166: 226-234. doi: 10.1016/j.drugalcdep.2016.07.017.

Yeatts, P. E. \& Lochbaum, M. (2013). Coping in sport: A test of Elliot's hierarchical model of approach and avoidance motivation. Kinesiology, 45(2): 186-193.

doi.10.1016/j.jshs.2015.07.008. 
Figure 1. Flowchart of research of scientific articles

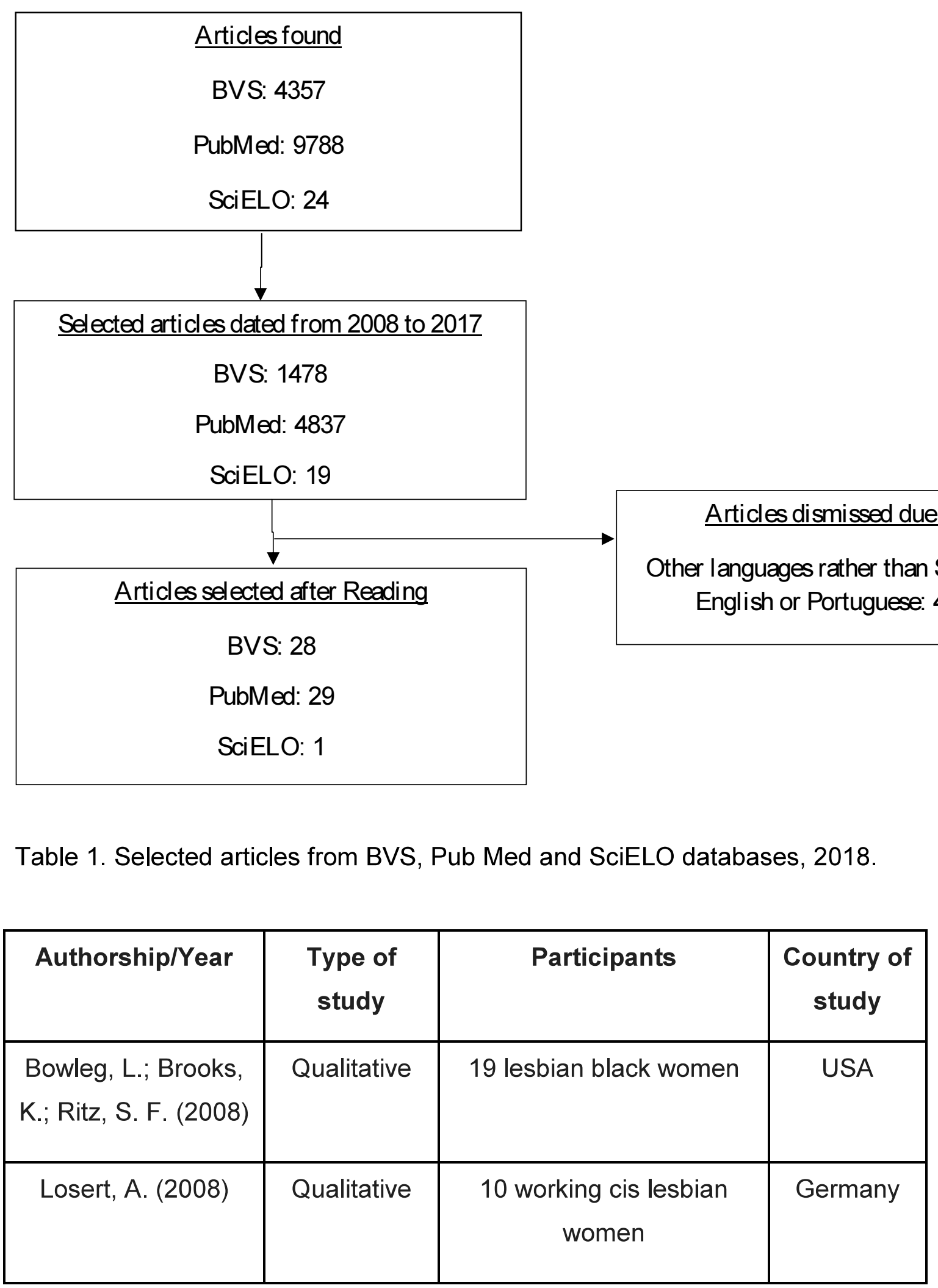




\begin{tabular}{|c|c|c|c|}
\hline $\begin{array}{c}\text { McDermott, E.; } \\
\text { Roen, K.; Scourfield, } \\
\text { J. (2008) }\end{array}$ & Qualitative & $\begin{array}{l}27 \text { young LGBT e others } \\
\text { from } 16 \text { to } 25 \text { years of age }\end{array}$ & $\begin{array}{l}\text { United } \\
\text { Kingdom }\end{array}$ \\
\hline $\begin{array}{c}\text { Meyer, I. H.; } \\
\text { Schwartz, S.; Frost, } \\
\text { D. M. (2008) }\end{array}$ & Quantitative & $\begin{array}{c}396 \text { cis LGB people and } \\
128 \text { heterossexuals }\end{array}$ & USA \\
\hline $\begin{array}{l}\text { Scourfield, J.; Roen, } \\
\text { K.; McDermott, L. } \\
\text { (2008) }\end{array}$ & Qualitative & $\begin{array}{l}69 \text { young LGBT and others } \\
\text { from } 16 \text { to } 25 \text { years of age }\end{array}$ & $\begin{array}{l}\text { United } \\
\text { Kingdom }\end{array}$ \\
\hline $\begin{array}{l}\text { Hequembourg, A. L.; } \\
\text { Brailler, S. A. (2009) }\end{array}$ & Qualitative & 43 LGB people & USA \\
\hline $\begin{array}{c}\text { MacKenzie, D.; } \\
\text { Huntington, A.; } \\
\text { Gilmour, J. A. (2009) }\end{array}$ & Qualitative & $\begin{array}{l}\text { Three intersex people (one } \\
\text { lesbian and two non-binary } \\
\text { people) }\end{array}$ & $\begin{array}{c}\text { New } \\
\text { Zealand }\end{array}$ \\
\hline $\begin{array}{l}\text { Matsumoto, Y. et al. } \\
\text { (2009) }\end{array}$ & Quantitative & 334 trans people & Japan \\
\hline $\begin{array}{c}\text { Santos, A. F.; } \\
\text { Fernandes, S. C. S. } \\
\text { (2009) }\end{array}$ & Quantitative & 31 homoaffective people & Brazil \\
\hline $\begin{array}{l}\text { Martin, J. I.; Alessi, } \\
\text { E. J. (2010) }\end{array}$ & Quantitative & $\begin{array}{c}297 \text { cis and trans, gay and } \\
\text { bissexual men }\end{array}$ & USA \\
\hline $\begin{array}{c}\text { Pendragon, D. K. } \\
\text { (2010) }\end{array}$ & Qualitative & $\begin{array}{l}15 \text { women from sexual } \\
\text { minorities }\end{array}$ & USA \\
\hline
\end{tabular}




\begin{tabular}{|c|c|c|c|}
\hline Choi, K. et al. (2011) & Qualitative & $\begin{array}{c}85 \text { African-American, Latin, } \\
\text { Asian and Oceanic men } \\
\text { who have sex with other } \\
\text { men }\end{array}$ & USA \\
\hline $\begin{array}{l}\text { Ephrem, B.; White, } \\
\text { A. M. (2011) }\end{array}$ & Qualitative & 5 lesbian cis women & Ethiopia \\
\hline $\begin{array}{c}\text { Leaper, C.; Arias, D. } \\
\text { M. (2011) }\end{array}$ & Quantitative & $\begin{array}{l}160 \text { heterossexual women, } \\
2 \text { bissexual women, } 1 \\
\text { lesbian woman, } 3 \text { women } \\
\text { from other orientations, } 3 \\
\text { women did not answer }\end{array}$ & USA \\
\hline $\begin{array}{c}\text { Monteiro, L. F.; } \\
\text { Machado, P. S.; } \\
\text { Nardi, H. C. (2011) }\end{array}$ & Qualitative & $\begin{array}{c}9 \text { lesbian cis women who } \\
\text { use a women's protection } \\
\text { service }\end{array}$ & Brazil \\
\hline Pelucio, L. (2011) & Qualitative & $\begin{array}{c}\text { Transvestites who are sex } \\
\text { workers }\end{array}$ & Brazil \\
\hline $\begin{array}{c}\text { Bjorkman, M.; } \\
\text { Malterud, K. (2012) }\end{array}$ & Qualitative & 64 lesbian women & Norway \\
\hline $\begin{array}{l}\text { Reed, S. J.; Valenti, } \\
\text { M. T. (2012) }\end{array}$ & Qualitative & $\begin{array}{c}14 \text { lesbian women from } 16 \\
\text { to } 24 \text { years of age }\end{array}$ & USA \\
\hline $\begin{array}{c}\text { Budge, S. L; } \\
\text { Adelson, J. L.; } \\
\text { Howard, K. A. S. } \\
\text { (2013) }\end{array}$ & Quantitative & 351 trans people & USA \\
\hline
\end{tabular}




\begin{tabular}{|c|c|c|c|}
\hline $\begin{array}{l}\text { Sornberg, M. J. et al. } \\
\qquad(2013)\end{array}$ & Quantitative & $\begin{array}{c}414 \text { young people from } 18 \\
\text { to } 25 \text { years of age, being } \\
207 \text { LGBQ and } 207 \\
\text { heterossexuals }\end{array}$ & Canada \\
\hline $\begin{array}{l}\text { Wagner, G. J. et al. } \\
\qquad(2013)\end{array}$ & Qualitative & $\begin{array}{c}31 \text { men who have sex with } \\
\text { other men }\end{array}$ & Lebanon \\
\hline $\begin{array}{l}\text { Mereish, E. H.; } \\
\text { O'Cleirigh, C.; } \\
\text { Bradford, J. B. } \\
\quad(2014)\end{array}$ & Quantitative & $\begin{array}{c}1457 \text { LGBT people } \\
\text { assisted by a community } \\
\text { health center }\end{array}$ & USA \\
\hline Wang, Y. (2014) & Qualitative & $\begin{array}{l}\text { One fifty-year-old cis } \\
\text { lesbian woman that was } \\
\text { raped by another woman }\end{array}$ & USA \\
\hline $\begin{array}{c}\text { Bariola, E. et al. } \\
\qquad(2015)\end{array}$ & Quantitative & 169 trans people & Australia \\
\hline $\begin{array}{l}\text { Barret, C. et al. } \\
\qquad(2015)\end{array}$ & Qualitative & $\begin{array}{c}30 \text { adult and elderly LGBT } \\
\text { people, } 9 \text { of which with } \\
\text { dementia }\end{array}$ & Australia \\
\hline $\begin{array}{c}\text { D'haese, L.; } \\
\text { Dewaele, A.; Van } \\
\text { Houtte, M. (2015) }\end{array}$ & Qualitative & 19 LGB people & Belgium \\
\hline $\begin{array}{l}\text { DiFulvio, G. T. } \\
\text { (2015) }\end{array}$ & Qualitative & One trans teenager & USA \\
\hline $\begin{array}{l}\text { Erhard, R. L.; Ben- } \\
\text { Ami, E. (2015) }\end{array}$ & Qualitative & $\begin{array}{c}20 \text { LGB high-school } \\
\text { student }\end{array}$ & Israel \\
\hline
\end{tabular}




\begin{tabular}{|c|c|c|c|}
\hline Ha, H. et al. (2015) & Quantitative & $\begin{array}{l}451 \text { men who have sex } \\
\text { with other men }\end{array}$ & Vietnam \\
\hline $\begin{array}{l}\text { Hamdi, N.; Lachheb, } \\
\text { M.; Anderson, E. } \\
\qquad(2015)\end{array}$ & Qualitative & $\begin{array}{c}\text { Three cis lesbian athlete } \\
\text { women }\end{array}$ & Tunísia \\
\hline $\begin{array}{l}\text { Itzhaky, H.; Kissil, K. } \\
\qquad(2015)\end{array}$ & Qualitative & $\begin{array}{l}22 \text { cis gay men orthodox } \\
\text { Jews who did not come out } \\
\text { for the religious community }\end{array}$ & USA \\
\hline $\begin{array}{l}\text { Marshall, A. et al. } \\
\qquad(2015)\end{array}$ & Qualitative & $\begin{array}{l}16 \text { teenagers from } 15 \text { to } 20 \\
\text { years of age who suffered } \\
\text { from violence at school } \\
\text { due to the perception of } \\
\text { their minority sexual } \\
\text { orientation }\end{array}$ & USA \\
\hline $\begin{array}{l}\text { Mason, T. B.; Lewis, } \\
\text { R. J. (2015) }\end{array}$ & Quantitative & $\begin{array}{l}164 \text { cis lesbian and } \\
\text { bissexual women }\end{array}$ & USA \\
\hline $\begin{array}{l}\text { Peacock, E.; } \\
\text { Andrinopoulos, K.; } \\
\text { Hembling, J. (2015) }\end{array}$ & Quantitative & $\begin{array}{c}670 \text { men who have sex } \\
\text { with other men and trans } \\
\text { women }\end{array}$ & El Salvador \\
\hline $\begin{array}{l}\text { Shilo, G.; Yossef, I.; } \\
\text { Savaya, R. (2015) }\end{array}$ & Quantitative & $\begin{array}{l}113 \text { gay and bisexual } \\
\text { Israeli men with high levels } \\
\text { of religiousness }\end{array}$ & Israel \\
\hline
\end{tabular}




\begin{tabular}{|c|c|c|c|}
\hline $\begin{array}{l}\text { Reisner, S. L. et al. } \\
\qquad(2015)\end{array}$ & Quantitative & 2.578 trans men & USA \\
\hline $\begin{array}{l}\text { Rowe, C. et al. } \\
\text { (2015) }\end{array}$ & Quantitative & 292 trans women & USA \\
\hline $\begin{array}{c}\text { Shires, D. A.; Jaffee, } \\
\text { K. D. (2015) }\end{array}$ & Quantitative & 4781 trans people & USA \\
\hline $\begin{array}{l}\text { Wang, J. et al. } \\
\text { (2015) }\end{array}$ & Quantitative & 762 cis gay men & Switzerland \\
\hline $\begin{array}{l}\text { Bogart, L. M. et al. } \\
\qquad(2016)\end{array}$ & Quantitative & $\begin{array}{l}27 \text { black hiv-positive men } \\
\text { who have sex with other } \\
\text { men }\end{array}$ & USA \\
\hline Choi, K. et al. (2016) & Quantitative & $\begin{array}{l}493 \text { men who have sex } \\
\text { with other men }\end{array}$ & China \\
\hline $\begin{array}{l}\text { Elm, J. H. L. et al. } \\
\qquad(2016)\end{array}$ & Qualitative & 11 two-spirit women & USA \\
\hline $\begin{array}{c}\text { Freeland, R.; } \\
\text { Goldenberg, T.; } \\
\text { Stephenson, R. } \\
\text { (2016) }\end{array}$ & Qualitative & 64 gay and bissexual men & USA \\
\hline $\begin{array}{l}\text { Gilbert, P. A. et al. } \\
\qquad(2016)\end{array}$ & Qualitative & $\begin{array}{l}15 \text { Latin foreign men who } \\
\text { have sex with Latin foreign } \\
\text { men }\end{array}$ & USA \\
\hline
\end{tabular}




\begin{tabular}{|c|c|c|c|}
\hline $\begin{array}{c}\text { Riley, T. C. et al. } \\
\text { (2016) }\end{array}$ & Quantitative & $\begin{array}{c}75 \text { university students from } \\
\text { sexual minorities and 1702 } \\
\text { heterossexuals }\end{array}$ & USA \\
\hline $\begin{array}{c}\text { Rood, B. A. et al. } \\
\text { (2016) }\end{array}$ & Qualitative & $\begin{array}{c}30 \text { trans and/or non- } \\
\text { gender-conforming people }\end{array}$ & USA \\
\hline $\begin{array}{c}\text { Sattler, F. A.; } \\
\text { Wagner, U.; } \\
\text { Christiansen, H. } \\
\text { (2016) }\end{array}$ & Quantitative & 1.188 cis gay men & Germany \\
\hline $\begin{array}{c}\text { Wilson, P. A. et al. } \\
\text { (2016) }\end{array}$ & Quantitative & $\begin{array}{c}228 \text { young black bissexual } \\
\text { ou gay cis men }\end{array}$ & USA \\
\hline $\begin{array}{c}\text { Wray T. B. et al. } \\
\text { (2016) }\end{array}$ & Quantitative & $\begin{array}{c}368 \text { men who have sex } \\
\text { with other men }\end{array}$ & USA \\
\hline $\begin{array}{c}\text { M. (2017) } \\
\text { Bry, L. J. et al. }\end{array}$ & Qualitative & $\begin{array}{c}10 \text { cis men from sexual } \\
\text { minorities and trans } \\
\text { (2017) }\end{array}$ & Uomen from 18 to 22 years \\
of age & USA \\
\hline $\begin{array}{c}\text { Arístegui, I. et al. } \\
\text { (2017) }\end{array}$ & Qualitative & $\begin{array}{c}18 \text { cis gay men and 17 } \\
\text { trans women }\end{array}$ & Argentina \\
\hline
\end{tabular}




\begin{tabular}{|c|c|c|c|}
\hline $\begin{array}{c}\text { Ganju, D.; Saggurti, } \\
\text { N. (2017) }\end{array}$ & Qualitative & $\begin{array}{c}68 \text { trans people who are } \\
\text { sex workers }\end{array}$ & India \\
\hline $\begin{array}{l}\text { Goldbach, J. T.; } \\
\text { Gibbs, J. J. (2017) }\end{array}$ & Qualitative & $\begin{array}{c}48 \text { teenagers from sexual } \\
\text { minorities from } 14 \text { to } 19 \\
\text { years of age }\end{array}$ & USA \\
\hline $\begin{array}{c}\text { McDermott, E.; } \\
\text { Hughes, E.; } \\
\text { Rawlings, V. (2017) }\end{array}$ & $\begin{array}{l}\text { Mixed } \\
\text { methodology }\end{array}$ & $\begin{array}{c}818 \text { LGBTQ people from } \\
16 \text { to } 25 \text { years of age }\end{array}$ & $\begin{array}{l}\text { United } \\
\text { Kingdom }\end{array}$ \\
\hline $\begin{array}{l}\text { Toomey, R. B. et al. } \\
\qquad(2017)\end{array}$ & Quantitative & $\begin{array}{l}245 \text { LGB adults from } 21 \text { to } \\
25 \text { years of age about } \\
\text { experiences related to } \\
\text { teenage years (13 to } 19 \\
\text { years of age) }\end{array}$ & USA \\
\hline
\end{tabular}

Table 2. Groups and number of coping strategies found, 2018

\begin{tabular}{|c|c|}
\hline Strategy groups & $\mathbf{n}$ \\
\hline Search for social support & 20 \\
\hline Concealing gender identity or sexual orientation & 14 \\
\hline Use of alcohol or other drugs & 11 \\
\hline Social isolation & 11 \\
\hline Resilient thinking & 10 \\
\hline Search for healthy environments & 9 \\
\hline
\end{tabular}




\begin{tabular}{|c|c|}
\hline Physically or verbally confronting the aggressor & 8 \\
\hline Self-destructive behaviour & 8 \\
\hline Owning gender identity or sexual orientation & 7 \\
\hline Ideation and attempted suicide & 5 \\
\hline Educating the aggressor or surrounding people on LGBTI+ themes & 4 \\
\hline Activism & 3 \\
\hline & $\mathrm{n}=110$ \\
\hline
\end{tabular}

Comprovante de submissão de artigo, requisito para defesa de dissertação.

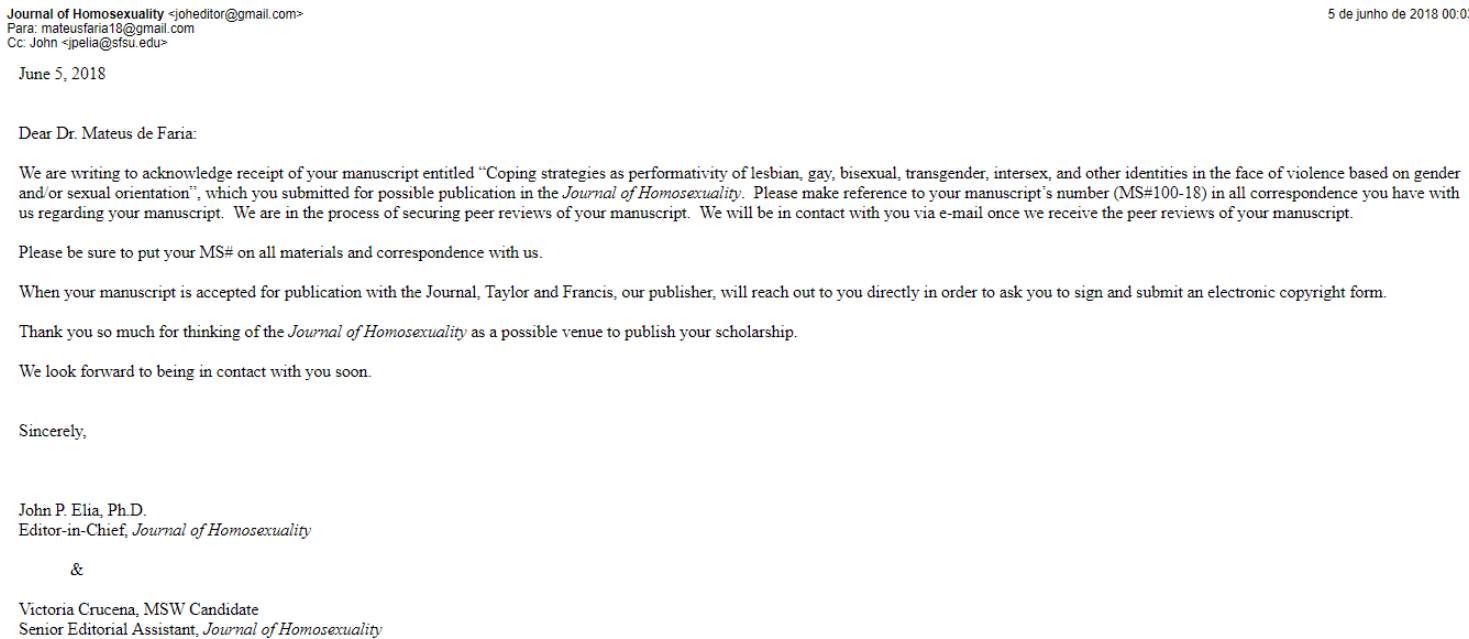

We are writing to acknowledge receipt of your manuscript entitled "Coping strategies as performativity of lesbian, gay, bisexual, transgender, intersex, and other identities in the face of violence based on gender and or sexual orientation", which you submitted for possible publication in the Journal of Homosexuality. Please make reference to your manuscript's number (MS\#100-18) in all correspondence you have with us regarding your manuscript. We are in the process of securing peer reviews of your manuscript. We will be in contact with you via e-mail once we receive the peer reviews of your manuscript.

Please be sure to put your MS\# on all materials and correspondence with us.

When your manuscript is accepted for publication with the Journal, Taylor and Francis, our publisher, will reach out to you directly in order to ask you to sign and submit an electronic copyright form. Thank you so much for thinking of the Jowrnal of Homosexuality as a possible venue to publish your scholarship.

We look forward to being in contact with you soon.

Sincerely,

John P. Elia, Ph.D.

Editor-in-Chief, Journal of Homosexuality

Victoria Crucena MSW Candide

Senior Editorial Assistant, Journal of Homosexuality 
9.4 Artigo de revisão sobre violências contra pessoas LGBTIQ+ a ser traduzido e submetido ao Journal of Interpersonal Violence.

VIOLÊNCIAS DE GÊNERO E/OU ORIENTAÇÃO SEXUAL CONTRA LÉSBICAS, GAYS, BISSEXUAIS, TRANGÊNEROS, INTERSEXUAIS, QUEER E OUTRAS IDENTIDADES: explicitando o ethos violento

\section{RESUMO}

Essa revisão integrativa da literatura buscou identificar e analisar as violências de gênero e/ou orientação sexual sofridas pela comunidade LGBTIQ+. A busca dos artigos foi feita nas bases de dados BVS, SciELO e PubMed e os critérios de inclusão foram artigos publicados entre 2008 e 2017, escritos em língua espanhola, inglesa ou portuguesa e que descrevessem atos de violência cometidos a pessoas que se identificassem como LGBTIQ+. Os resultados mostraram que a maioria dos trabalhos está em língua inglesa, proveniente dos Estados Unidos da América e que adotaram percursos metodológicos quantitativos. A quantidade de produções aumentou até 2013, mantendo relativa estabilidade até 2017, com pico em 2016. Vários subgrupos e nomeações foram descritas na literatura. Minorias sociais e homens que fazem sexo com outros homens foram os mais frequentes. As violências perpassam aspectos físicos, psicológicos, emocionais, verbais e patrimoniais. Durante toda a vida a comunidade LGBTIQ+ é violentada e em diferentes espaços de convívio. A violência praticada pelo cônjuge aparece com bastante frequência, evidenciado a interseccionalidade. Tais violências são cenas enunciativas promovidas pelo ethos coletivo e anacrônico que buca sua reprodução e naturalização pelo extermínio de conflitos gerados por corpos dissidentes de sua norma.

PALAVRAS-CHAVE: Violência, minorias sexuais, LGBT. 


\section{INTRODUÇÃO}

A violência vivenciada pela população de lésbicas, gays, bissexuais, travestis, transexuais, intersexuais, queer e outras identidades, que aqui designaremos como LGBTIQ+, tem sido de múltiplas vertentes, o que leva a refletir na pluralização desse termo: são, na verdade, violências motivadas pelo preconceito e discriminação em torno dos gêneros e/ou das identidades sexuais (Minayo, 2016; Otero et al., 2015; Ducan; Hatzenbuehler; Johnson, 2014; Guenewald, 2012).

Essa produção da violência cujos alvos são corpos diversos que rebelam-se contra uma hegemonia cis-heteronormativa é a forma com que o ethos coletivo, anacrônico e compulsório busca manter-se no presente, pressupondo unidade e exterminando contradições, a fim de se naturalizar no cotidiano social (Butler, 2015; Schramm, 2009). Assim a materialização do ethos acontece nos corpos que danifica, a partir de dispositivos como a escola e o sistema de saúde e de outros corpos que, momentaneamente, corroboram com essas violências ao reproduzi-las. É momentânea uma vez que ninguém possui o monopólio da opressão (Butler, 2015b), portanto se em determinada cena enunciativa um homem trans é violentado por conta de seu gênero considerado desviante logo passível de correção, em outro contexto ele pode ser o perpetrador da violência contra mulheres negras, por exemplo. Assim o ethos circula e se invisibiliza ao passo que se dilui nas relações sociais.

Estudos anteriores têm mostrado a violência entre casais LGBTIQ+ (Otero et al., 2015), evolução dos estudos e discursos científicos sobre violência contra a comunidade LGBTQ+ (McKay, Lindquist \& Misra, 2017) e as taxas de violências motivadas pela percepção de gêneros e/ou orientação sexual (Blondeel et al., 2018). No entanto, pouco se sabe sobre o panorama das violências, tanto da variedade de atos violentos vivenciados quanto pela diferença geográfica, racial e outros marcadores interseccionais que afetam essa população. Sendo assim, o objetivo desse artigo é identificar e analisar as violências relatadas na literatura científica pela população LGBTIQ+. 


\section{METODOLOGIA}

Foi realizada uma revisão integrativa de literatura, entendida como a busca ampla de trabalhos científicos, incluídos aqueles experimentais e não experimentais a fim de compreender 0 objeto de pesquisa $\circ$ mais completamente possível. Tal vasto panorama pretendido deverá ser igualmente consistente e compreensivo de fenômenos e conceitos complexos (Souza et al., 2010).

As bases de dados da Biblioteca Virtual em Saúde (BVS/Bireme), da Biblioteca Nacional de Medicina (PubMed) e a Scientific Eletronic Library Online (SciELO) foram utilizadas para essa revisão. Os descritores utilizados foram "violência" e suas combinações com "minorias sexuais", "homossexualidade", "pessoas transgênero", "identidade de gênero", "gênero e saúde" e "sexismo". A escolha dos termos para pesquisa se deu em função de consultas realizadas ao portal de Descritores das Ciências da Saúde (DeCS) e ao Medical Subject Headings (MeSH), sendo considerados os mais próximos da pergunta de pesquisa.

Os critérios de inclusão foram: I) artigos publicados a partir de 2008 a 2017, com o intuito de verificar o estado da arte nos últimos dez anos completos; II) trabalhos em português, inglês ou espanhol, III) título e resumo condizentes com o tema de pesquisa. Foram consideradas produções científicas que tivessem natureza empírica, por metodologias quantitativas e/ou qualitativas, resultantes de pesquisas com a população LGBTIQ+ e que especificassem quais estratégias as pessoas participantes da pesquisa empregavam em relação a quaisquer tipos de violência por motivações ligadas ao gênero ou à orientação sexual. Foram excluídos, portanto, artigos exclusivamente teóricoconceituais assim como os artigos iguais encontrados em estratégias de buscas e/ou bancos de dados diferentes.

Graficamente a busca por produções científicas foi construída da seguinte maneira: 
Gráfico 1 - Fluxograma de busca de artigos

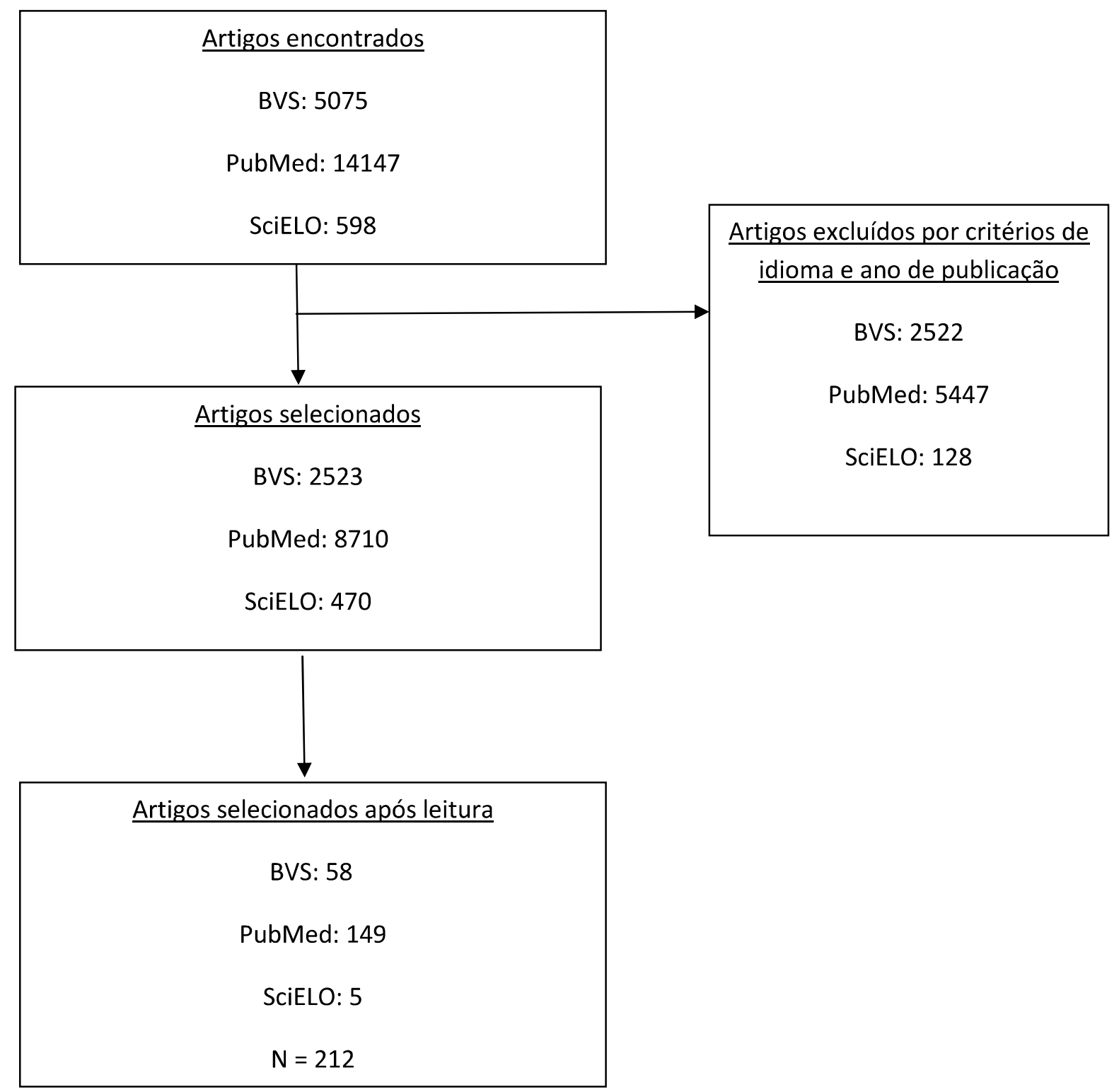

Os valores acima referem-se ao somatório dos resultados encontrados a partir da combinação de descritores em cada base de dados utilizada. A queda acentuada de artigos selecionados de deu por conta de um grande conjunto de trabalhos não explicitar de quais violências estavam tratando ou ainda considerar gênero como sendo a oposição homem/mulher. 


\section{RESULTADOS}

Os artigos selecionados a partir dos critérios de inclusão foram majoritariamente escritos em língua inglesa $(92,9 \%, n=197)$, sendo provenientes principalmente do continente americano e utilizando metodologias quantitativas para consecução de objetivos, conforme os gráficos 2 e 3 demonstram.

Gráfico 2 - Proporção de artigos segundo percurso metodológico, 2008-2017.

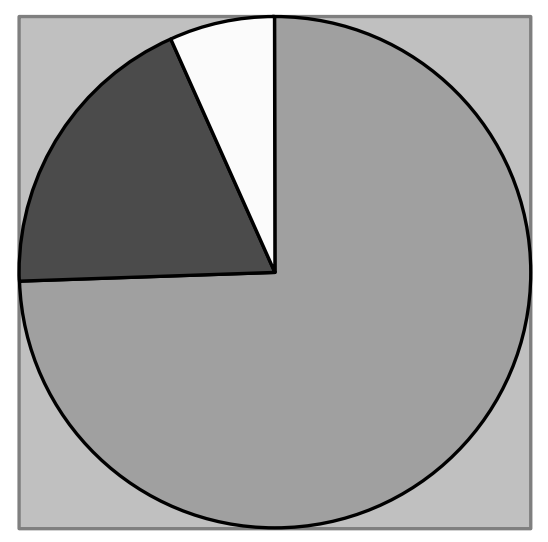

$\square$ Quantitativo $(n=158)$ $\square$ Qualitativo $(n=40)$

$\square$ Quantiqualitativo $(n=14)$

Gráfico 3 - Proporção de artigos segundo continente pesquisado, 2008-2017

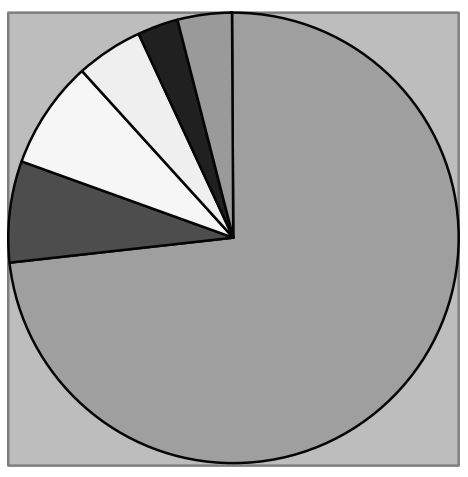

$\square$ Américas $(n=155)$

$\square$ Ásia $(n=16)$

$\square$ Europa $(n=16)$

$\square$ África $(n=10)$

$\square$ Oceania $(\mathrm{n}=7)$

$\square$ Mais de um cont inente $(n=8)$

Dentro das Américas, os Estados Unidos é o país com mais produções $(n=114)$, seguido de Brasil $(n=14)$ e Canadá $(n=13)$. Já China $(n=5)$ e Índia $(n=4)$ são os países asiáticos com mais artigos selecionados. Na Europa, Reino Unido $(n=3)$ e Suécia $(n=3)$ são os mais frequentes. No continente africano, a África do Sul é a origem mais frequente dos artigos $(n=3)$. Austrália 
$(n=5)$ é o país com mais produções segundo o continente oceânico. Oito artigos relataram pesquisas que abrangeram mais de um continente ou não delimitaram a extensão territorial da pesquisa por conta da utilização de questionários online. Ao longo do tempo, a produção de artigos sobre violência contra pessoas LGBTIQ+ cresceu, mantendo-se relativamente estável desde 2013, com pico em $2016(n=42)$, conforme mostrado pelo gráfico 4 .

Gráfico 4 - Evolução dos artigos por ano, 2008-2017.

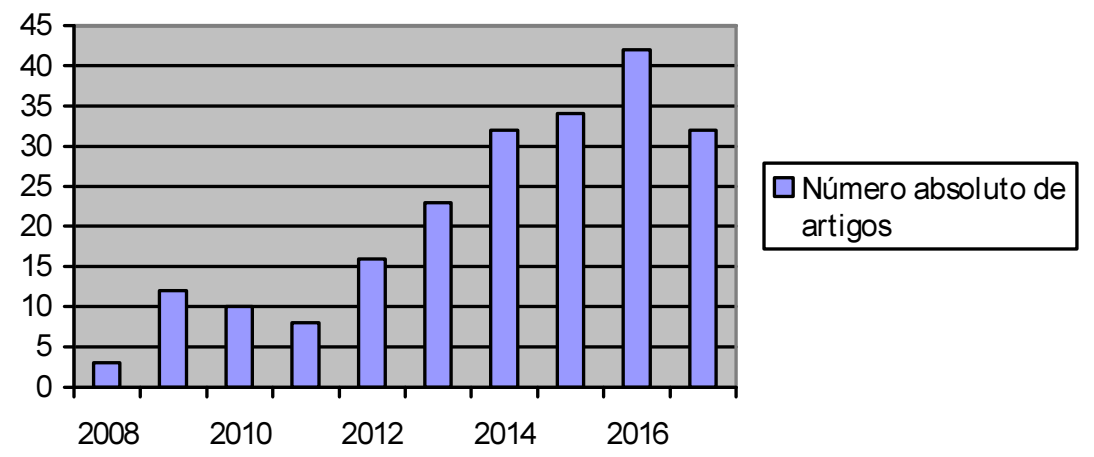

A utilização de várias combinações de descritores objetivou abarcar o maior número de nomeações para essa população e isso é corroborado pela diversidade de siglas e subgrupos participantes das pesquisas. Apesar de um número expressivo de artigos ser sobre comparações entre pessoas heterossexuais e/ou cis e subgrupos LGBTIQ+ $(43,9 \%, n=93)$, a maioria foca exclusivamente em questões ontologicamente dissidentes.

Homens que fazem sexo com outros homens $(\mathrm{HSH})$ foi o grupo que participou de mais pesquisas $(11,8 \%, n=25)$, incluindo $\mathrm{HSH}$ que vivem com o vírus HIV (Araujo et al., 2009; Kennedy et al., 2013; Pantalone et al., 2014; Phillips et al., 2014) e profissionais do sexo (Micheni et al., 2015). Outro subgrupo que esteve presente em 10,8\% ( $n=23)$ dos artigos analisados foi o de homens trans e de mulheres trans/travestis/transfemininas/hijra - a variedade de nomeações deve-se ao fato de que as pessoas que são designadas ao nascer como meninos e ao longo da vida rompem com essa norma imposta para performatizar gêneros femininos identificam-se a partir da cultura local, do posicionamento político e de outras esferas sociais que possibilitam ou 
constrangem essas ontologias. O estudo de Wijngaarden et al. (2013) é um dos exemplos que busca, a partir dos relatos de hijra - comunidade religiosa hinduísta presente em países asiáticos como Índia e Paquistão - compreender as violências contra essa população. Outro grupo que é regionalizado são as pessoas que se identificam como travestis, presentes em países latinos, participantes das pesquisas de Pollock et al. (2016), Silva et al. (2016), Souza et al. (2015) e Duanny \& Navarrol (2008). Também presente em 6,6\% dos artigos, está homens gays e bissexuais (GB), sendo uma das formas de rearranjo da sigla LGBTIQ+: outras são LGBT, LGB, LGBTI, apenas lésbicas, pessoas trans, lésbicas e gays, LGBTT, LGBTQ, HSH e GBT, lésbicas e mulheres bissexuais, apenas homens gays, lésbicas e queer, mulheres que fazem sexo com mulheres ou ainda apenas pessoas queer. Não foram selecionados artigos que mostrassem pesquisas apenas com pessoas bissexuais. Tais conformações de amostras de pesquisas objetivaram, principalmente, comparações entre pessoas com diferentes orientações sexuais e/ou identidades de gêneros a fim de corroborar hipóteses de maior ou menor ocorrência de violências.

Sobre as cenas violentas, iniciaremos com as relatadas em pesquisas com lésbicas. Grande parte dos artigos que relatam as vivências desse subgrupo buscou estimar coeficientes de prevalência para abuso infantil e na vida adulta de várias naturezas, taxa de vitimização e índices de comparação com outros grupos como bissexuais, queer e heterossexuais. De modo geral, mulheres lésbicas são mais vítimas de violências, de atos abusivos, seja física, verbal, patrimonial ou sexualmente (Reuter et al., 2017; Lira, 2016; Eduarda \& Sylaska, 2015; Tait, 2015; Andersen et al., 2014; Han et al., 2013; Hequembourg et al., 2013; Pelullo et al., 2013; Levitt et al., 2012; Wilsnack et al., 2012; Hughes et al., 2010; Roberts et al., 2010; Smith et al., 2010). Os perpetradores frequentemente estão próximos como tios, vizinhos e conhecidos (Wilsnack et al., 2012) ou ainda são discriminadas no trabalho (Herek, 2009). Uma parte dos artigos focou em grupos de mulheres dissidentes da heteronormatividade $\mathrm{e}$ suas experiências violentas. O conjunto de mulheres lésbicas, bissexuais e queer relatou sofrer abusos físicos, emocionais e sexuais por familiares, 
bullying na escola, violências verbais, físicas e sexuais na etapa adulta da vida, falta de referências e informações sobre suas ontologias, maior controle de corpos em áreas rurais e exacerbação da violência se foram profissionais do sexo (Corliss et al., 2009; Levahot et al., 2009; Johnson et al., 2011; Sweet \& Welles, 2012; Kuhar \& Svab, 2015; Levahot \& Simpson, 2014; Lyons et al., 2014a, 2014b; D'haese et al., 2015; Micheni et al., 2015; Sandfort et al., 2015; Flynn et al., 2016) sendo ainda culpabilizadas por todos esses atos (Alhusen et al., 2011).

As violências contra homens gays foi temática de alguns trabalhos, que apontaram que a discriminação é maior em casa (Herek, 2009; BarrientosDelgado et al., 2014), que as taxas de prevalência de abuso infantil de quaisquer naturezas, discriminação por conta da orientação sexual, agressões física e sexual, assédio moral no trabalho, exclusão do mercado de trabalho motivada pela orientação sexual $e$ isolamento forçado são maiores que heterossexuais (Siqueira et al., 2009; Han et al., 2013; Pelullo et al., 2013; Barrientos-Delgado et al., 2014; Soliva \& Silva Junior, 2014; Edwards \& Sylaska, 2015). Pessoas que se identificam como HSH apontaram o cotidiano violento em que (sobre)vivem, com atos simbólicos, físicos, psicológicos, sexuais, verbais e emocionais que, na infância e na vida adulta, marcaram negativamente suas trajetórias (Araujo et al., 2009; Welles et al, 2011; Dunkle et al., 2013; Eloward \& Essen, 2013; Aho et al., 2014; De Santis et al., 2014; Schillder et al., 2014; Wheeler et al., 2014; Geter et al., 2015; Micheni et al., 2015; Sekoni et al., 2015; Peitzmeier et al., 2015; Semple et al., 2016; Tomori et al., 2016; Magno et al., 2017; Mgopa et al., 2017). Marcadores de diferenças entre $\mathrm{HSH}$, como viver com HIV e negros, exacerbam os atos violentos relatados (Araujo et al., 2009; Bernoit \& Downing Jr., 2013; Kennedy et al., 2013; King et al., 2013; Phillips et al., 2014; Ports et al., 2017).

Sobre as pessoas bissexuais, autores(as) como Conron et al. (2010), Hughes et al. (2010), Roberts et al. (2010), Alvy et al. (2013), Hequembourg et al. (2013), Andersen et al. (2014), Toit (2015), Zoy \& Andersen (2015) e Eisenberg et al. (2017) apontam que as mulheres bissexuais são vítimas de violência doméstica, de assédio sexual, de abusos na infância e de violência em geral do 
que homens bissexuais. Por outro lado, este subgrupo tem menor cobertura por planos de saúde e acesso mais dificultado ao sistema de saúde (Conron et al., 2010). A congruência ocorre quando é demonstrado as taxas de estupro e tentativas de estupro, de bullying, de ameaças para assumir-se, de expulsão de casa e de outros tipos de violências notadamente superiores em relação à comunidade LGBTIQ+ e cis-heterossexuais (Blosnick \& Bossarte, 2012; McLaughlin et al., 2012; Axelsson et al., 2013; Shaw et al., 2012; Menning \& Holtzman, 2013; Pelullo et al., 2013; Andersen et al., 2015; Davis et al., 2015; Branstorm, 2016; Vertommen et al., 2016; Steele et al., 2017; Szalacha et al., 2017)

As vivências trans são também transversalizadas pelas violências, sendo estas baseadas em um fascismo binário (Rogers, 2016; Pendragon, 2010), em que pela dissidência do sistema linear sexo-gênero, as corporeidades trans são discriminadas, abusadas física, verbal, sexual e psicologicamente, expulsas material e simbolicamente - de casa, da escola, do mercado de trabalho (Duanny \& Navarrol, 2008; Nemoto et al., 2011; Toomey et al., 2012; Bradfort et al., 2013; Nuttbrock et al., 2014; DiFulvio, 2015; Souza et al., 2015; Langenderfer-Magruder e tal., 2016; Pollock et al., 2016; Scheim et al., 2016; Gowin et al., 2017; Lyons et al., 2017; Smith et al., 2017). Pessoas trans negras, que performatizam feminilidades e/ou profissionais do sexo são os alvos preferidos das violências (Rood et al., 2015; Silva et al., 2016; Dinno, 2017; Logie et al., 2017; Reuter et al., 2017; Rodriguez-Madera et al., 2017). Ontologias trans são perseguidas desde a infância, visto a alta prevalência de abusos sexuais infantis relatados por esse subgrupo (Bandini et al., 2011; Fernandez-Rouco et al., 2015; Cheney et al., 2017). A comunidade hijra aparece como de algumas pesquisas que mostram a alta vulnerabilidade a que são submetidas em seus países (Khan at el., 2009; Shaw et al., 2012; Wijngaarden et al., 2013; 2012; Li et al., 2016).

Muito artigos utilizaram o termo minorias sociais para nomear a população participante do estudo. Este conjunto de trabalhos possibilitou certo panorama sobre as violências, já que, ao englobar todas as ontologias dissentes da cisheteronormatividade, carrega consigo as violências cotidianas e pregressas 
das pessoas participantes. Sendo assim, maior risco de estupro, de abusos de várias naturezas e por diferentes perpetradores, de bullying, de evasão escolar, de coerção para "curar" da orientação sexual e de atos de higienização social são o resumo das violências motivadas pelo preconceito às orientações sexuais e/ou às identidades de gênero (Barrientos et al., 2010; Porter \& Williams, 2011; Edward \& Sylaska, 2012; Roberts et al., 2013; Russell et al., 2014; Zea et al., 2014; Alessi et al., 2015; Brown et al., 2015; Dunn et al., 2015; Natarelli et al., 2015; Oshri et al., 2015; Peter et al., 2015; Bouris et al., 2016; Donahue et al., 2016; Goodenow et al., 2016; Hopkinson et al., 2016; Miedema et al., 2016; Piwowarczyk et al., 2016; Sheridan et al., 2016; Elipe et al., 2017; Goldbach et al., 2017; Kahle et al;, 2017; Martinez \& McDonald, 2017).

De todas as cenas violentas descritas nos artigos, a perpetrada pelo(a) parceiro(a) foi a mais recorrente. Diversos trabalhos (Gillum \& DiFulvio, 2012; Martin-Storey, 2014; McCauley et al., 2014; Edwards, 2015; Edwards et al., 2015; Martin-Storey \& Fromme, 2016; DiStefano, 2017) demonstram que as pessoas $\mathrm{LGBTIQ}$ + têm maiores coeficientes de prevalência, estão mais propensas a serem vítimas e, por conseguinte, de serem também agressoras em um relacionamento do que pessoas cis-heterossexuais. Tal violência pelo(a) parceiro(a) íntimo(a) (VPI) pode acontece de modo físico (Lewis et al., 2017), além de estar em um espectro que varia entre agressões psicológicas até mutilações e estupro (Porter \& Williams, 2011; Geter et al., 2015; Olsen et al., 2017).

Outros estudos buscaram evidenciar as diferenças intragrupais em relação aos atos de VPI que vitimam pessoas LGBTIQ+. Um subgrupo que apareceu com bastante frequência devido aos resultados das pesquisas que evidenciaram sua vulnerabilização foi o de pessoas bissexuais. Os trabalhos de Goldberg \& Meyer (2013), Gonzalez-Guarda (2013) e Szalacha et al. (2017) apontam que esse subgrupo possui especificidades que provocam aumento da vitimização em relação à VPI, tendo ainda mais peso na trajetória de vida de mulheres bissexuais, por ameaças, isolamento coercitivo, retirada de preservativo sem 0 seu consentimento, pressão para engravidar, entre outras situações que buscam limitar seu corpo (Blosnich \& Bossarte, 2009; Hester-Donovan, 2009; 
Pyra et al., 2014; McCauley, 2015; Alexander et al., 2016; Dantas et al., 2016; Valentine et al., 2017). Homens bissexuais, cis e trans, também sofrem violências como sexo coercitivo, agressões físicas e verbais (Pathela et al., 2010; Valentine et al., 2017) ou, juntamente com homens gays, sofrem violências emocionais, físicas e sexuais (Bartholomew et al, 2008; Finneran \& Stephenson, 2013; Bacchus et al., 2016; Stephenson \& Finneran, 2016), discussões graves sobre infidelidade e relacionamento aberto (Woodyatt \& Stephenson, XXXX; Finneran \& Stephenson, 2014), atos violentos contra patrimônio e violência simbólica (Li \& Zheng, 2017). Martin-Storey \& Fromme (2017), Saldivia-Mansilla et al. (2017), Dank et al. (2014), McLaughling et al. (2012) e Mak et al. (2010) afirmam que, se acrescentar as vivências lésbicas nesse grupo de gays e bissexuais, teremos um grupo de orientações sexuais altamente vitimado pela VPI. E a multiplicidade de combinações dentro da sigla LGBTIQ+ sempre, de acordo com os artigos selecionados, resulta em condições de violência em relacionamentos maiores do que em uniões cisheterossexuais, incluindo abusos de diversas ordens, constrangimentos em público por conta de certos comportamentos julgados como inadequados, tentativas e consecuções de sexo coercitivo, ameaças de suicídio, entre outras (Sanger \& Lynch; 2017; Dardis et al., 2016; Davis et al., 2016; Goldenberg et al., 2016; Graham et al., 2016; Stults et al., 2016; Whitton et al., 2016; Zhang et al., 2016; Edwars \& Sylaska, 2015; Langenderfer-Magruder et al., 2015; Oliffe et al., 2014; Stephenson et al., 2014; Dunkle et al., 2013; Kanuha et al., 2013; Kanuha, 2013; Reisner et al, 2013; Yu et al., 2013; Siemieniuk et al., 2012; Stoffelen, 2012; Stephenson et al., 2011; Stephenson et al., 2010).

Outro ponto que se destaca aqui é as violências praticadas por agentes públicos, principalmente policiais e profissionais de saúde. O despreparo dessas duas classes trabalhadoras para lidar com casos de violências LGBTIQ+ é preponderante nos artigos analisados, principalmente sobre as necessidades sociais e de saúde de pessoas trans (Alhusen et al., 2011; Lyons et al., 2015; Souza et al., 2015; Rogers, 2016; Rosentel et al., 2016; Apóstolo, 2017; Quresh et al., 2017; Rodriguez-Madera et al., 2017). Ademais, as ações truculentas de policiais geralmente incorrem em agressões físicas, verbais, 
omissão de proteção e encarceramento ilegal de corpos ontologicamente percebidos como dissidentes da heteronormatividade, como os $\mathrm{HSH}$, travestis e pessoas transfemininas (Barrientos et al., 2010; Kennedy et al., 2013; King et al., 2013; Barrientos-Delgado et al., 2014; Socias et al., 2014; Peitzmeier et al., 2015; Souza et al., 2015; Scheim et al., 2016; Cheney et al., 2017; Mgopa et al., 2017; Rodriguez-Madera et al., 2017). No campo dos serviços de saúde, percebe-se que a estigmatização e preconceito é materializado nas relações profissional-paciente, resultando em mal atendimento ou até mesmo em negativa de assistência, desrespeito ao nome social, patologização de identidades LGBTIQ+ (Araújo et al., 2009; Khan et al., 2009; Bradford et al., 2013; Socias et al., 2014; Mizuno et al., 2014; Shires \& Jaffe, 2015; Dantas et al., 2016). Tal situação é agravada se o(a) paciente for profissional do sexo, soropositivo(a) ou precisar de hormonização (Shaw et al., 2012; Kennedy et al., 2013; King et al., 2013; Rosentel et al., 2016).

As ideações e tentativas de suicídio também foram presentes nos artigos analisados. O desejo de direcionar a violência para si mesmo é mais prevalente em pessoas LGBTIQ+ do que grupos cis-heterossexuais (Carliss et al., 2009; Zhao et al., 2010; Teixeira-Filho \& Rondini, 2012; Harris et al., 2013; Duncan \& Hatzenbueler, 2014; Sabidó et al., 2015; Bouris et al., 2016; Flynn et al., 2016; Apostolo, 2017; Magno et al., 2017), porém com diferenças intragrupais importantes. Estudos mostraram que pessoas negras, bissexuais e/ou trans relatam planejar e tentar autoextermínio com mais frequência que outras ontologias dissidentes (Blosnich \& Bossarte, 2012; McLaughlin et al., 2012; Lytle et al., 2014; Stone et al., 2014; DiFulvio, 2015; Rood et al., 2015; Souza et al., 2015; Lytle et al., 2016; Gowin et al., 2017; Taliaferro et al., 2017).

\section{DISCUSSÃO}

Essa revisão buscou reunir os artigos científicos que apontassem os atos violentos voltados à comunidade LGBTIQ+ e entende-los como parte de uma estratégia ethoica que se impõe no presente, porém pertence a um passado de concepções rígidas de ser humano. Alguns trabalhos demonstram isso mais 
nitidamente como Zea et al. (2014) que aponta práticas de higienização social promovida por grupos paramilitares. Não apenas pessoas LGBTIQ+, mas usuárias de drogas e com HIV são marginalizáveis, portanto passíveis de exclusão por certas características que as destituem de humanização. Tal cena violenta de exclusão, referenciada em outros trabalhos de forma menos explícita através do bullying, da expulsão de casa e das agressões de variadas ordens, vai além de atos isolados contra grupos específicos - é, de fato, uma hegemonia de âmbito mundial que objetiva eliminar contradições e conflitos para manter-se e reproduzir-se (BUTLER, 2015a; SCHRAMM, 2009). Percebese, então, que a percepção da existência de LGBTIQ+ já é em si um risco para tal ethos coletivo, pois desafia suas normas totalitárias, seu fascismo binário (Rogers, 2016; Pendragon, 2010). As corporeidades dissidentes desse regime hegemônico de ontologias disputam, por meio de suas práticas sociodiscursivas, direitos de existência e, com isso, constroem táticas de resistência como adereços, bandeiras, movimentos sociais (Monteiro, 2009). A contrarresposta aparece então com assédios, com rituais de "cura/conversão" das sexualidades, negligência de agentes públicos, insultos e demais atos de violências relatadas nos artigos. Apagar esses corpos ou, pelo menos, corrigilos são necessários para a coerência ethoica e, assim, contribuir para a naturalização das violências. $E$ quando as vítimas buscam espaços de proteção como amigos, família ou delegacias, a culpabilização pelo ato é imputada a elas (Wijngaarden et al., 2013; Alhusen et al., 2011; Kahn et al., 2009), deslegitimando qualquer direito à existência ou ao reconhecimento das cenas violentas (Canseco, 2015).

Importante salientar que as cenas enunciativas que envolvem LGBTIQ+e atos violentos estão atravessadas por fluxos de poder que são tão mais profundos quanto mais marcadores de diferenças estiverem interconectados (BRAH, 2006). Estudos mostraram que a vulnerabilização é maior em pessoas de minorias sociais que vivem com HIV, negras, moradoras de cidades interioranas e profissionais do sexo (Dinno, 2017; Logie et al., 2017; Kuhar \& Svab, 2014; Kennedy et al., 2013; King et al., 2013). Sendo assim, os atos de violência ethoicos não são exclusivos contra performatividades de gêneros ou 
orientações sexuais: são intersecções que iteradamente (re)produz desigualdades sociais (Bilge, 2009). Isso é importante no sentido de não perpetuar o apagamento de subjetividades dentro da comunidade LGBTIQ+, uma vez que tais diferenciações implicam em distintas cenas violentas e toda e qualquer intervenção contra elas necessita considerar que existem eixos de discriminação que se intercruzam e não se dissociam (Crenshaw, 2004). Outras cenas, como a VPI, evidenciam o não monopólio do lugar de oprimido por pessoas não cis-heterossexuais (Butler, 2015), em que a reprodução da violência acontece entre pares, os quais uma das pessoas possui performatiza marcadores de diferenças que provocam assimetrias nas relações de poder. Logo políticas públicas, leis de proteção e serviços especializados também não podem tratar dessas questões separadamente, justificadas por determinismos identitários.

Em estudo anterior, Otero et al. (2015) apontaram que o interesse acadêmico ainda se concentra fortemente sobre violências vivenciadas por pessoas lésbicas, gays ou bissexuais, apesar de haver crescimento de pesquisa sobre trajetórias de vida de travestis, transexuais e intersexuais. Os mesmos autores salientam a preponderância de estudos estadunidenses, de perspectiva qualitativa, que enumeram mais frequentemente violências psicológicas e de ordem emocional. Tais resultados assemelham-se aos aqui encontrado, no que tange o número de artigos sobre sujeitos trans pois foi o segundo em maior número na amostra selecionada. No entanto os estudos revisados há presença significativa sobre atos violentos de ordem física e VPI e percursos metodológicos quantitativos em maior quantidade que qualitativos.

Não foi objetivo desta revisão mensurar as taxas das diversas violências descritas na literatura. Em revisão sistemática apresentada por Blondeel et al. (2018) as autoras apontam que violências física e sexual por conta da identidade ou expressão de gênero e de orientação sexual são maiores em mulheres trans e pessoas transgênero - resultado este que converge com os aqui relatados sobre o subgrupo de pessoas trans que sofrem imposições de vulnerabilização sobre seus corpos e seus modos de vida. Blondeel et al., 
(2018) ainda afirmam que há preponderância de estudos em língua inglesa e provenientes dos EUA, resultado idêntico ao encontrado aqui.

Outra revisão de literatura (McKay, Lindquist \& Misra, 2017) apresenta resultados semelhantes aos encontrados nessa revisão como o aumento dos casos de violências contra pessoas LGBTIQ+, a presença de atos violentos durante toda a vida - da criança ao idoso - e o fato de que os maiores perpetradores são pessoas próximas como familiares. Acrescentamos, a partir de nossos resultados, que os atos violentos são diferenciados a partir das ontologias dos corpos-alvo, não sendo as violências igualmente distribuídas entre pessoas LGBTIQ+, mas sim tendo especificidades para cada subgrupo.

\section{CONSIDERAÇÕES FINAIS}

Conhecer as violências perpetradas contra a comunidade LGBTIQ+ e compreendê-las como materializações do ethos anacrônico e violento é possibilitar o reconhecimento de que elas não são naturais, nem motivadas pelas suas vítimas. As mortes físicas e simbólicas dessa comunidade explicitam nossa incapacidade enquanto sociedade de entender o outro como necessário para constituição do eu, em uma relação de interdependência e solidariedade. A exclusão aplica-se ao que não é útil ou necessário, marginalizando pessoas por meio da desumanização.

Essa revisão não encontrou artigos que focassem especificamente em relatos de pessoas intersexo, o que nos leva a algumas reflexões: elas estão diluídas em nomeações como minorias sexuais ou pessoas transgênero? Suas vivências são semelhantes às da comunidade LGBTQ+ em geral? As violências sobre seus corpos são (re)conhecidas? Além disso, as limitações da pesquisa concernem ao fato de termos considerado apenas três idiomas, em bases científicas mais utilizadas pela comunidade latina e europeia, restringindo $O$ alcance $e$, com isso, 0 panorama das violências contra a comunidade LGBTIQ+. 
Propomos novas pesquisas e intervenções sobre as violências LGBTIQ+e suas interseccionalidades, de modo a buscar subsídio para políticas públicas mais integrativas em relação às diferenças intragrupais dessa comunidade.

\section{REFERÊNCIAS}

Aho, J., Hakim, A., Vuylsteke, B., Semde, G., Gbais, H., \& Diarrassouba, M. et al. (2014). Exploring Risk Behaviors and Vulnerability for HIV among Men Who Have Sex with Men in Abidjan, Cote d'Ivoire: Poor Knowledge, Homophobia and Sexual Violence. Plos ONE, 9(6), e99591. doi: 10.1371/journal.pone.0099591

Alessi, E., Kahn, S., \& Chatterji, S. (2016). 'The darkest times of my life': Recollections of child abuse among forced migrants persecuted because of their sexual orientation and gender identity. Child Abuse \& Neglect, 51, 93105. doi: $10.1016 / j$.chiabu.2015.10.030

Alexander, K., Volpe, E., Abboud, S., \& Campbell, J. (2016). Reproductive coercion, sexual risk behaviours and mental health symptoms among young low-income behaviourally bisexual women: implications for nursing practice. Journal Of Clinical Nursing, 25(23-24), 3533-3544. doi: 10.1111/jocn.13238

Alhusen, J., Lucea, M., \& Glass, N. (2010). Perceptions of and Experience With System Responses to Female Same-Sex Intimate Partner Violence. Partner Abuse, 1(4), 443-462. doi: 10.1891/1946-6560.1.4.443

Alvy, L., Hughes, T., Kristjanson, A., \& Wilsnack, S. (2013). Sexual Identity Group Differences in Child Abuse and Neglect. Journal Of Interpersonal Violence, 28(10), 2088-2111. doi: 10.1177/0886260512471081

Andersen, J., Hughes, T., Zou, C., \& Wilsnack, S. (2014). Lifetime Victimization and Physical Health Outcomes among Lesbian and Heterosexual Women. Plos ONE, 9(7), e101939. doi: 10.1371/journal.pone.0101939

Apóstolo, M., Moscheta, M., \& Souza, L. (2017). Discursos e posicionamentos em um encontro de diálogo sobre violência a LGBTs. Psicologia USP, 28(2), 266-275. doi: 10.1590/0103-656420150064

Araújo, M., Montagner, M., da Silva, R., Lopes, F., \& de Freitas, M. (2009). Symbolic Violence Experienced by Men Who Have Sex with Men in the Primary Health Service in Fortaleza, Ceará, Brazil: Negotiating Identity Under Stigma. AIDS Patient Care And Stds, 23(8), 663-668. doi: 10.1089/apc.2008.0123

Axelsson, J., Modén, B., Rosvall, M., \& Lindström, M. (2013). Sexual orientation and self-rated health: the role of social capital, offence, threat of violence, 
and violence. Scandinavian Journal Of Public Health, 41(5), 508-515. doi: $10.1177 / 1403494813476159$

Bacchus, L., Buller, A., Ferrari, G., Peters, T., Devries, K., \& Sethi, G. et al. (2016). Occurrence and impact of domestic violence and abuse in gay and bisexual men: A cross sectional survey. International Journal Of STD \& AIDS, 28(1), 16-27. doi: 10.1177/0956462415622886

Bandini, E., Fisher, A., Ricca, V., Ristori, J., Meriggiola, M., \& Jannini, E. et al. (2011). Childhood maltreatment in subjects with male-to-female gender identity disorder. International Journal Of Impotence Research, 23(6), 276285. doi: 10.1038/ijir.2011.39

Barrientos, J., Silva, J., Catalan, S., Gómez, F., \& Longueira, J. (2010). Discrimination and Victimization: Parade for Lesbian, Gay, Bisexual, and Transgender (LGBT) Pride, in Chile. Journal Of Homosexuality, 57(6), 760775. doi: $10.1080 / 00918369.2010 .485880$

Barrientos-Delgado, J., Cárdenas-Castro, M., \& Gómez-Ojeda, F. (2014). Características sociodemográficas, bienestar subjetivo y homofobia en una muestra de hombres gay en tres ciudades chilenas. Cadernos De Saúde Pública, 30(6), 1259-1269. doi: 10.1590/0102-311x00108413

Bartholomew, K., Regan, K., White, M., \& Oram, D. (2008). Patterns of Abuse in Male Same-Sex Relationships. Violence And Victims, 23(5), 617-636. doi: 10.1891/0886-6708.23.5.617

Benoit, E., \& Downing, M. (2013). Childhood sexual experiences among substance-using non-gay identified Black men who have sex with men and women. Child Abuse \& Neglect, 37(9), 679-690. doi:

10.1016/j.chiabu.2013.04.007

Blondeel, K., de Vasconcelos, S., García-Moreno, C., Stephenson, R., Temmerman, M., \& Toskin, I. (2018). Violence motivated by perception of sexual orientation and gender identity: a systematic review. Bulletin of the World Health Organization, 96(1), 29-41L. http://doi.org/10.2471/BLT.17.197251

Blosnich, J., \& Bossarte, R. (2009). Comparisons of Intimate Partner Violence Among Partners in Same-Sex and Opposite-Sex Relationships in the United States. American Journal Of Public Health, 99(12), 2182-2184. doi: 10.2105/ajph.2008.139535

Bradford, J., Reisner, S., Honnold, J., \& Xavier, J. (2013). Experiences of Transgender-Related Discrimination and Implications for Health: Results From the Virginia Transgender Health Initiative Study. American Journal Of Public Health, 103(10), 1820-1829. doi: 10.2105/ajph.2012.300796

Brah, A. (2006). Diferença, diversidade, diferenciação. Cadernos Pagu, (26), 329-376. doi: 10.1590/s0104-83332006000100014 
Bouris, A., Everett, B., Heath, R., Elsaesser, C., \& Neilands, T. (2016). Effects of Victimization and Violence on Suicidal Ideation and Behaviors Among Sexual Minority and Heterosexual Adolescents. LGBT Health, 3(2), 153161. doi: $10.1089 / \mathrm{lgbt} .2015 .0037$

Bränström, R. (2017). Minority stress factors as mediators of sexual orientation disparities in mental health treatment: a longitudinal population-based study. Journal Of Epidemiology And Community Health, 71(5), 446-452. doi: 10.1136/jech-2016-207943

Brown, M., Masho, S., Perera, R., Mezuk, B., \& Cohen, S. (2015). Sex and sexual orientation disparities in adverse childhood experiences and early age at sexual debut in the United States: Results from a nationally representative sample. Child Abuse \& Neglect, 46, 89-102. doi: 10.1016/j.chiabu.2015.02.019

Butler, J. (2015). Relatar a si mesmo: crítica da violência ética. Belo Horizonte: Autêntica.

Canseco, A. (2015). Reconhecer a violência. Sex., Salud Soc. (Rio J.), 19, 133148.

Cheney, M., Gowin, M., Taylor, E., Frey, M., Dunnington, J., \& Alshuwaiyer, G. et al. (2017). Living Outside the Gender Box in Mexico: Testimony of Transgender Mexican Asylum Seekers. American Journal Of Public Health, 107(10), 1646-1652. doi: 10.2105/ajph.2017.303961

Conron, K., Mimiaga, M., \& Landers, S. (2010). A Population-Based Study of Sexual Orientation Identity and Gender Differences in Adult Health. American Journal Of Public Health, 100(10), 1953-1960. doi: 10.2105/ajph.2009.174169

Corliss, H., Cochran, S., Mays, V., Greenland, S., \& Seeman, T. (2009). Age of minority sexual orientation development and risk of childhood maltreatment and suicide attempts in women. American Journal Of Orthopsychiatry, 79(4), 511-521. doi: 10.1037/a0017163

Crenshaw, K. (2018). A intersecionalidade na discriminação de raça e gênero. In A. W., Estudos Feministas. Brasília: Unifemm.

D'haese, L., Dewaele, A., \& Van Houtte, M. (2015). The Relationship Between Childhood Gender Nonconformity and Experiencing Diverse Types of Homophobic Violence. Journal Of Interpersonal Violence, 31(9), 16341660. doi: $10.1177 / 0886260515569063$

Dank, M., Lachman, P., Zweig, J., \& Yahner, J. (2013). Dating Violence Experiences of Lesbian, Gay, Bisexual, and Transgender Youth. Journal Of Youth And Adolescence, 43(5), 846-857. doi: 10.1007/s10964-013-9975-8

Dantas, B., Lucena, ,., Deininger, L., Andrade, C., \& Monteiro, A. (2016). VIOLÊNCIA DE GÊNERO NAS RELAÇÕES LÉSBICAS. Rev Enferm UFPE On Line, 10(11), 3989-95. 
Dardis, C., Shipherd, J., \& Iverson, K. (2016). Intimate partner violence among women veterans by sexual orientation. Women \& Health, 57(7), 775-791. doi: $10.1080 / 03630242.2016 .1202884$

Davis, A., Best, J., Wei, C., Luo, J., Van Der Pol, B., \& Meyerson, B. et al. (2015). Intimate Partner Violence and Correlates With Risk Behaviors and HIVISTI Diagnoses Among Men Who Have Sex With Men and Men Who Have Sex With Men and Women in China. Sexually Transmitted Diseases, 42(7), 387-392. doi: 10.1097/olq.0000000000000302

Davis, A., Kaighobadi, F., Stephenson, R., Rael, C., \& Sandfort, T. (2016). Associations Between Alcohol Use and Intimate Partner Violence Among Men Who Have Sex with Men. LGBT Health, 3(6), 400-406. doi: 10.1089/lgbt.2016.0057

De Santis, J., Gonzalez-Guarda, R., Provencio-Vasquez, E., \& Deleon, D. (2013). The Tangled Branches (Las Ramas Enredadas). Journal Of Transcultural Nursing, 25(1), 23-32. doi: 10.1177/1043659613504110

DiFulvio, G. (2014). Experiencing Violence and Enacting Resilience. Violence Against Women, 21(11), 1385-1405. doi: 10.1177/1077801214545022

Dinno, A. (2017). Homicide Rates of Transgender Individuals in the United States: 2010-2014. American Journal Of Public Health, 107(9), 1441-1447. doi: 10.2105/ajph.2017.303878

DiStefano, A. (2009). Intimate Partner Violence Among Sexual Minorities in Japan: Exploring Perceptions and Experiences. Journal Of Homosexuality, 56(2), 121-146. doi: 10.1080/00918360802623123

Donahue, K., Långström, N., Lundström, S., Lichtenstein, P., \& Forsman, M. (2017). Familial Factors, Victimization, and Psychological Health Among Sexual Minority Adolescents in Sweden. American Journal Of Public Health, 107(2), 322-328. doi: 10.2105/ajph.2016.303573

Duanny-Navarrol, A. (2008). TRASTORNOS DE IDENTIDAD SEXUAL Y VIOLENCIA. Rev. Hosp. Psiquiátrico De La Habana, 5(1).

Duncan, D., \& Hatzenbuehler, M. (2014). Lesbian, Gay, Bisexual, and Transgender Hate Crimes and Suicidality Among a Population-Based Sample of Sexual-Minority Adolescents in Boston. American Journal Of Public Health, 104(2), 272-278. doi: 10.2105/ajph.2013.301424

Duncan, D., Hatzenbuehler, M., \& Johnson, R. (2014). Neighborhood-level LGBT hate crimes and current illicit drug use among sexual minority youth. Drug And Alcohol Dependence, 135, 65-70. doi: 10.1016/j.drugalcdep.2013.11.001

Dunkle, K., Jewkes, R., Murdock, D., Sikweyiya, Y., \& Morrell, R. (2013). Prevalence of Consensual Male-Male Sex and Sexual Violence, and Associations with HIV in South Africa: A Population-Based Cross-Sectional Study. Plos Medicine, 10(6), e1001472. doi: 10.1371/journal.pmed.1001472 
Dunn, H., Clark, M., \& Pearlman, D. (2015). The Relationship Between Sexual History, Bullying Victimization, and Poor Mental Health Outcomes Among Heterosexual and Sexual Minority High School Students: A Feminist Perspective. Journal Of Interpersonal Violence, 32(22), 3497-3519. doi: $10.1177 / 0886260515599658$

Edwards, K. (2015). Incidence and Outcomes of Dating Violence Victimization Among High School Youth: The Role of Gender and Sexual Orientation. Journal Of Interpersonal Violence, 33(9), 1472-1490. doi: $10.1177 / 0886260515618943$

Edwards, K., \& Sylaska, K. (2012). The Perpetration of Intimate Partner Violence among LGBTQ College Youth: The Role of Minority Stress. Journal Of Youth And Adolescence, 42(11), 1721-1731. doi: 10.1007/s10964-012-9880-6

Edwards, K., \& Sylaska, K. (2015). Reactions to Participating in Intimate Partner Violence and Minority Stress Research: A Mixed Methodological Study of Self-Identified Lesbian and Gay Emerging Adults. The Journal Of Sex Research, 53(6), 655-665. doi: 10.1080/00224499.2015.1035428

Edwards, K., Sylaska, K., Barry, J., Moynihan, M., Banyard, V., \& Cohn, E. et al. (2014). Physical Dating Violence, Sexual Violence, and Unwanted Pursuit Victimization. Journal Of Interpersonal Violence, 30(4), 580-600. doi: $10.1177 / 0886260514535260$

Eisenberg, M., Lust, K., Mathiason, M., \& Porta, C. (2017). Sexual Assault, Sexual Orientation, and Reporting Among College Students. Journal Of Interpersonal Violence, 088626051772641. doi: $10.1177 / 0886260517726414$

Elipe, P., de la Oliva Muñoz, M., \& Del Rey, R. (2017). Homophobic Bullying and Cyberbullying: Study of a Silenced Problem. Journal Of Homosexuality, 65(5), 672-686. doi: 10.1080/00918369.2017.1333809

Elouard, Y., \& Essén, B. (2013). Psychological Violence Experienced by Men Who Have Sex With Men in Puducherry, India: A Qualitative Study. Journal Of Homosexuality, 60(11), 1581-1601. doi: 10.1080/00918369.2013.824325

Fernández-Rouco, N., Fernández-Fuertes, A., Carcedo, R., Lázaro-Visa, S., \& Gómez-Pérez, E. (2016). Sexual Violence History and Welfare in Transgender People. Journal Of Interpersonal Violence, 32(19), 2885-2907. doi: $10.1177 / 0886260516657911$

Finneran, C., \& Stephenson, R. (2013). Gay and Bisexual Men's Perception of Police Helpfulness in Response to Male-Male Intimate Partner Violence. Western Journal Of Emergency Medicine, 14(4), 354-362. doi: 10.5811/westjem.2013.3.15639

Finneran, C., \& Stephenson, R. (2014). Antecedents of Intimate Partner Violence Among Gay and Bisexual Men. Violence And Victims, 29(3), 422435. doi: 10.1891/0886-6708.vv-d-12-00140 
Flynn, A., Johnson, R., Bolton, S., \& Mojtabai, R. (2016). Victimization of Lesbian, Gay, and Bisexual People in Childhood: Associations with Attempted Suicide. Suicide And Life-Threatening Behavior, 46(4), 457-470. doi: $10.1111 /$ sltb. 12228

Geter, A., Ricks, J., McGladrey, M., Crosby, R., Mena, L., \& Ottmar, J. (2016). Experiences of Antihomosexual Attitudes and Young Black Men Who Have Sex with Men in the South: A Need for Community-Based Interventions. LGBT Health, 3(3), 214-218. doi: 10.1089/lgbt.2015.0031

Gillum, T., \& DiFulvio, G. (2012). "There's So Much at Stake": sexual minority youth discuss dating violence. Violence Against Women, 18(7), 725-745. doi: $10.1177 / 1077801212455164$

Goldbach, J., Raymond, H., \& Burgess, C. (2017). Patterns of Bullying Behavior by Sexual Orientation. Journal Of Interpersonal Violence, 088626051774162 . doi: $10.1177 / 0886260517741623$

Goldberg, N., \& Meyer, I. (2012). Sexual Orientation Disparities in History of Intimate Partner Violence. Journal Of Interpersonal Violence, 28(5), 11091118. doi: $10.1177 / 0886260512459384$

Goldenberg, T., Stephenson, R., Freeland, R., Finneran, C., \& Hadley, C. (2016). 'Struggling to be the alpha': sources of tension and intimate partner violence in same-sex relationships between men. Culture, Health \& Sexuality, 18(8), 875-889. doi: 10.1080/13691058.2016.1144791

Gonzalez-Guarda, R., De Santis, J., \& Vasquez, E. (2013). Sexual Orientation and Demographic, Cultural, and Psychological Factors Associated with the Perpetration and Victimization of Intimate Partner Violence among Hispanic Men. Issues In Mental Health Nursing, 34(2), 103-109. doi:

10.3109/01612840.2012.728280

Goodenow, C., Watson, R., Adjei, J., Homma, Y., \& Saewyc, E. (2016). Sexual orientation trends and disparities in school bullying and violence-related experiences, 1999-2013. Psychology Of Sexual Orientation And Gender Diversity, 3(4), 386-396. doi: 10.1037/sgd0000188

Gowin, M., Taylor, E., Dunnington, J., Alshuwaiyer, G., \& Cheney, M. (2017). Needs of a Silent Minority: Mexican Transgender Asylum Seekers. Health Promotion Practice, 18(3), 332-340. doi: 10.1177/1524839917692750

Graham, L., Jensen, T., Givens, A., Bowen, G., \& Rizo, C. (2016). Intimate Partner Violence Among Same-Sex Couples in College. Journal Of Interpersonal Violence, 088626051665162 . doi: $10.1177 / 0886260516651628$

Gruenewald, J. (2012). Are Anti-LGBT Homicides in the United States Unique?. Journal Of Interpersonal Violence, 27(18), 3601-3623. doi: $10.1177 / 0886260512462301$

Han, S., Gallagher, M., Franz, M., Chen, M., Cabral, F., \& Marx, B. (2013). Childhood Sexual Abuse, Alcohol Use, and PTSD Symptoms as Predictors 
of Adult Sexual Assault Among Lesbians and Gay Men. Journal Of Interpersonal Violence, 28(12), 2505-2520. doi:

$10.1177 / 0886260513479030$

Harris, K. (2013). Sexuality and Suicidality: Matched-Pairs Analyses Reveal Unique Characteristics in Non-Heterosexual Suicidal Behaviors. Archives Of Sexual Behavior, 42(5), 729-737. doi: 10.1007/s10508-013-0112-2

Hequembourg, A., Livingston, J., \& Parks, K. (2013). Sexual Victimization and Associated Risks Among Lesbian and Bisexual Women. Violence Against Women, 19(5), 634-657. doi: 10.1177/1077801213490557

Herek, G. (2008). Hate Crimes and Stigma-Related Experiences Among Sexual Minority Adults in the United States. Journal Of Interpersonal Violence, 24(1), 54-74. doi: 10.1177/0886260508316477

Hester, M., \& Donovan, C. (2009). Researching Domestic Violence in SameSex Relationships-A Feminist Epistemological Approach to Survey Development. Journal Of Lesbian Studies, 13(2), 161-173. doi: 10.1080/10894160802695346

Miedema, S., Yount, K., Chirwa, E., Dunkle, K., \& Fulu, E. (2016). Integrating male sexual diversity into violence prevention efforts with men and boys: evidence from the Asia-Pacific Region. Culture, Health \& Sexuality, 19(2), 208-224. doi: 10.1080/13691058.2016.1214747

Hughes, T., Szalacha, L., Johnson, T., Kinnison, K., Wilsnack, S., \& Cho, Y. (2010). Sexual victimization and hazardous drinking among heterosexual and sexual minority women. Addictive Behaviors, 35(12), 1152-1156. doi: 10.1016/j.addbeh.2010.07.004

Johnson, R., Kidd, J., Dunn, E., Green, J., Corliss, H., \& Bowen, D. (2011). Associations Between Caregiver Support, Bullying, and Depressive Symptomatology Among Sexual Minority and Heterosexual Girls: Results From the 2008 Boston Youth Survey. Journal Of School Violence, 10(2), 185-200. doi: 10.1080/15388220.2010.539168

Kahle, L. (2017). Are Sexual Minorities More at Risk? Bullying Victimization Among Lesbian, Gay, Bisexual, and Questioning Youth. Journal Of Interpersonal Violence, 088626051771883. doi: $10.1177 / 0886260517718830$

Kanuha, V. (2013). "Relationships So Loving and So Hurtful". Violence Against Women, 19(9), 1175-1196. doi: 10.1177/1077801213501897

Kennedy, C., Baral, S., Fielding-Miller, R., Adams, D., Dludlu, P., \& Sithole, B. et al. (2013). "They are human beings, they are Swazi": intersecting stigmas and the positive health, dignity and prevention needs of HIVpositive men who have sex with men in Swaziland. Journal Of The International AIDS Society, 16, 18749. doi: 10.7448/ias.16.4.18749

Khan, S. I., Hussain, M. I., Parveen, S., Bhuiyan, M. I., Gourab, G., Sarker, G. F., ... Sikder, J. (2009). Living on the Extreme Margin: Social Exclusion of 
the Transgender Population (Hijra) in Bangladesh. Journal of Health, Population, and Nutrition, 27(4), 441-451.

King, R., Barker, J., Nakayiwa, S., Katuntu, D., Lubwama, G., \& Bagenda, D. et al. (2013). Men at Risk; a Qualitative Study on HIV Risk, Gender Identity and Violence among Men Who Have Sex with Men Who Report High Risk Behavior in Kampala, Uganda. Plos ONE, 8(12), e82937. doi: 10.1371/journal.pone.0082937

Kuhar, R., \& Švab, A. (2014). The Only Gay in the Village? Everyday Life of Gays and Lesbians in Rural Slovenia. Journal Of Homosexuality, 61(8), 1091-1116. doi: 10.1080/00918369.2014.872492

Langenderfer-Magruder, L., Whitfield, D., Walls, N., Kattari, S., \& Ramos, D. (2014). Experiences of Intimate Partner Violence and Subsequent Police Reporting Among Lesbian, Gay, Bisexual, Transgender, and Queer Adults in Colorado. Journal Of Interpersonal Violence, 31(5), 855-871. doi: 10.1177/0886260514556767

Langenderfer-Magruder, L., Walls, n., Kattari, S., Whitfield, D., \& Ramos, D. (2016). Sexual Victimization and Subsequent Police Reporting by Gender Identity Among Lesbian, Gay, Bisexual, Transgender, and Queer Adults. Violence And Victims, 31(2), 320-331. doi: 10.1891/0886-6708.vv-d14-00082

Lehavot, K., \& Simpson, T. (2014). Trauma, posttraumatic stress disorder, and depression among sexual minority and heterosexual women veterans. Journal Of Counseling Psychology, 61(3), 392-403. doi: $10.1037 / \mathrm{cou} 0000019$

Lehavot, K., Walters, K., \& Simoni, J. (2009). Abuse, mastery, and health among lesbian, bisexual, and two-spirit American Indian and Alaska Native women. Cultural Diversity And Ethnic Minority Psychology, 15(3), 275-284. doi: $10.1037 / a 0013458$

Levitt, H., Puckett, J., Ippolito, M., \& Horne, S. (2012). Sexual Minority Women's Gender Identity and Expression: Challenges and Supports. Journal Of Lesbian Studies, 16(2), 153-176. doi: 10.1080/10894160.2011.605009

Lewis, R., Mason, T., Winstead, B., \& Kelley, M. (2017). Empirical investigation of a model of sexual minority specific and general risk factors for intimate partner violence among lesbian women. Psychology Of Violence, 7(1), 110119. doi: $10.1037 /$ vio0000036

Li, D., Rawat, S., Rhoton, J., Patankar, P., Ekstrand, M., Rosser, B., \& Wilkerson, J. (2016). Harassment and Violence Among Men Who Have Sex with Men (MSM) and Hijras After Reinstatement of India's "Sodomy Law". Sexuality Research And Social Policy, 14(3), 324-330. doi: 10.1007/s13178-016-0270-9

Li, D., \& Zheng, L. (2017). Intimate Partner Violence and Controlling Behavior Among Male Same-Sex Relationships in China: Relationship With 
Ambivalent Sexism. Journal Of Interpersonal Violence, 088626051772483. doi: $10.1177 / 0886260517724835$

Lira, A., Morais, N., \& Boris, G. (2016). (In)Visibilidade da Vivência Homoparental Feminina: entre Preconceitos e Superações. Psicologia: Ciência E Profissão, 36(1), 20-33. doi: 10.1590/1982-3703000152014

Logie, C., Wang, Y., Lacombe-Duncan, A., Jones, N., Ahmed, U., \& Levermore, $\mathrm{K}$. et al. (2017). Factors associated with sex work involvement among transgender women in Jamaica: a cross-sectional study. Journal Of The International AIDS Society, 20(1), 21422. doi: 10.7448/ias.20.01/21422

Lyons, T., Kerr, T., Duff, P., Feng, C., \& Shannon, K. (2014). Youth, violence and non-injection drug use: nexus of vulnerabilities among lesbian and bisexual sex workers. AIDS Care, 26(9), 1090-1094. doi: 10.1080/09540121.2013.869542

Lyons, T., Shannon, K., Richardson, L., Simo, A., Wood, E., \& Kerr, T. (2015). Women Who Use Drugs and Have Sex with Women in a Canadian Setting: Barriers to Treatment Enrollment and Exposure to Violence and Homelessness. Archives Of Sexual Behavior, 45(6), 1403-1410. doi: 10.1007/s10508-015-0508-2

Lyons, T., Krüsi, A., Pierre, L., Kerr, T., Small, W., \& Shannon, K. (2016). Negotiating Violence in the Context of Transphobia and Criminalization. Qualitative Health Research, 27(2), 182-190. doi: 10.1177/1049732315613311

Lytle, M., Blosnich, J., \& Kamen, C. (2016). The Association of Multiple Identities with Self-Directed Violence and Depression among Transgender Individuals. Suicide And Life-Threatening Behavior, 46(5), 535-544. doi: $10.1111 / \mathrm{sltb} .12234$

Magno, L., Dourado, I., Silva, L., Brignol, S., Brito, A., \& Guimarães, M. et al. (2017). Factors associated with self-reported discrimination against men who have sex with men in Brazil. Revista De Saúde Pública, 51, 102. doi: 10.11606/s1518-8787.2017051000016

Mak, W., Chong, E., \& Kwong, M. (2010). Prevalence of same-sex intimate partner violence in Hong Kong. Public Health, 124(3), 149-152. doi: 10.1016/j.puhe.2010.02.002

Martin-Storey, A. (2014). Prevalence of Dating Violence Among Sexual Minority Youth: Variation Across Gender, Sexual Minority Identity and Gender of Sexual Partners. Journal Of Youth And Adolescence, 44(1), 211-224. doi: 10.1007/s10964-013-0089-0

Martin-Storey, A., \& Fromme, K. (2016). Trajectories of dating violence: Differences by sexual minority status and gender. Journal Of Adolescence, 49, 28-37. doi: 10.1016/j.adolescence.2016.02.008

Martin-Storey, A., \& Fromme, K. (2017). Mediating Factors Explaining the Association Between Sexual Minority Status and Dating Violence. Journal 
Of Interpersonal Violence, 088626051772697 . doi: $10.1177 / 0886260517726971$

Martinez, K., \& McDonald, C. (2017). Childhood Familial Victimization: An Exploration of Gender and Sexual Identity Using the Scale of Negative Family Interactions. Journal Of Interpersonal Violence, 088626051773928. doi: $10.1177 / 0886260517739289$

McCauley, H., Dick, R., Tancredi, D., Goldstein, S., Blackburn, S., \& Silverman, J. et al. (2014). Differences by Sexual Minority Status in Relationship Abuse and Sexual and Reproductive Health Among Adolescent Females. Journal Of Adolescent Health, 55(5), 652-658. doi:

10.1016/j.jadohealth.2014.04.020

McCauley, H., Silverman, J., Decker, M., Agénor, M., Borrero, S., \& Tancredi, D. et al. (2015). Sexual and Reproductive Health Indicators and Intimate Partner Violence Victimization Among Female Family Planning Clinic Patients Who Have Sex with Women and Men. Journal Of Women's Health, 24(8), 621-628. doi: 10.1089/jwh.2014.5032

McKay, T., Lindquist, C., \& Misra, S. (2017). Understanding (and Acting On) 20 Years of Research on Violence and LGBTQ + Communities. Trauma, Violence, \& Abuse, 152483801772870. doi: 10.1177/1524838017728708

McLaughlin, K., Hatzenbuehler, M., Xuan, Z., \& Conron, K. (2012). Disproportionate exposure to early-life adversity and sexual orientation disparities in psychiatric morbidity. Child Abuse \& Neglect, 36(9), 645-655. doi: 10.1016/j.chiabu.2012.07.004

Menning, C., \& Holtzman, M. (2013). Processes and Patterns in Gay, Lesbian, and Bisexual Sexual Assault. Journal Of Interpersonal Violence, 29(6), 1071-1093. doi: $10.1177 / 0886260513506056$

Mgopa, L., Mbwambo, J., Likindikoki, S., \& Pallangyo, P. (2017). Violence and depression among men who have sex with men in Tanzania. BMC Psychiatry, 17(1). doi: 10.1186/s12888-017-1456-2

Micheni, M., Rogers, S., Wahome, E., Darwinkel, M., van der Elst, E., \& Gichuru, E. et al. (2015). Risk of sexual, physical and verbal assaults on men who have sex with men and female sex workers in coastal Kenya. AIDS, 29, S231-S236. doi: 10.1097/qad.0000000000000912

Miedema, S., Yount, K., Chirwa, E., Dunkle, K., \& Fulu, E. (2016). Integrating male sexual diversity into violence prevention efforts with men and boys: evidence from the Asia-Pacific Region. Culture, Health \& Sexuality, 19(2), 208-224. doi: 10.1080/13691058.2016.1214747

Mizuno, Y., Frazier, E., Huang, P., \& Skarbinski, J. (2015). Characteristics of Transgender Women Living with HIV Receiving Medical Care in the United States. LGBT Health, 2(3), 228-234. doi: 10.1089/lgbt.2014.0099 
Monteiro, L. (2009). Rompendo o silêncio: homofobia e heterossexismo nas trajetórias de vida de mulheres (Master). Universidade Federal do Rio Grande do Sul.

Natarelli, T., Braga, I., Oliveira, W., \& Silva, M. (2015). The Impact of homophobia on adolescent health. Escola Anna Nery - Revista De Enfermagem, 19(4). doi: 10.5935/1414-8145.20150089

Nemoto, T., Bödeker, B., \& Iwamoto, M. (2011). Social Support, Exposure to Violence and Transphobia, and Correlates of Depression Among Male-toFemale Transgender Women With a History of Sex Work. American Journal Of Public Health, 101(10), 1980-1988. doi: 10.2105/ajph.2010.197285

Nuttbrock, L., Bockting, W., Rosenblum, A., Hwahng, S., Mason, M., Macri, M., \& Becker, J. (2014). Gender Abuse and Major Depression Among Transgender Women: A Prospective Study of Vulnerability and Resilience. American Journal Of Public Health, 104(11), 2191-2198. doi: 10.2105/ajph.2013.301545

Oliffe, J., Han, C., Maria, E., Lohan, M., Howard, T., Stewart, D., \& MacMillan, $H$. (2014). Gay men and intimate partner violence: a gender analysis. Sociology Of Health \& Illness, 36(4), 564-579. doi: 10.1111/14679566.12099

Olsen, E., Vivolo-Kantor, A., \& Kann, L. (2017). Physical and Sexual Teen Dating Violence Victimization and Sexual Identity Among U.S. High School Students, 2015. Journal Of Interpersonal Violence, 088626051770875. doi: $10.1177 / 0886260517708757$

Oshri, A., Handley, E., Sutton, T., Wortel, S., \& Burnette, M. (2014).

Developmental Trajectories of Substance Use Among Sexual Minority Girls: Associations With Sexual Victimization and Sexual Health Risk. Journal Of Adolescent Health, 55(1), 100-106. doi: 10.1016/j.jadohealth.2013.11.009

Otero, Luis Manuel Rodríguez, Carrera Fernández, Maria Victoria, Lameiras Fernández, María, \& Rodríguez Castro, Yolanda. (2015). Violencia en parejas transexuales, transgénero e intersexuales: una revisión bibliográfica. Saúde e Sociedade, 24(3), 914935. https://dx.doi.org/10.1590/S0104-12902015134224

Pantalone, D., Horvath, K., Hart, T., Valentine, S., \& Kaysen, D. (2014). Traumatic Revictimization of Men Who Have Sex With Men Living With HIVIAIDS. Journal Of Interpersonal Violence, 30(9), 1459-1477. doi: $10.1177 / 0886260514540802$

Pathela, P., \& Schillinger, J. (2010). Sexual Behaviors and Sexual Violence: Adolescents With Opposite-, Same-, or Both-Sex Partners. PEDIATRICS, 126(5), 879-886. doi: 10.1542/peds.2010-0396 
Peitzmeier, S., Yasin, F., Stephenson, R., Wirtz, A., Delegchoimbol, A., Dorjgotov, M., \& Baral, S. (2015). Sexual Violence against Men Who Have Sex with Men and Transgender Women in Mongolia: A Mixed-Methods Study of Scope and Consequences. PLOS ONE, 10(10), e0139320. doi: 10.1371/journal.pone. 0139320

Peitzmeier, S., Stephenson, R., Delegchoimbol, A., Dorjgotov, M., \& Baral, S. (2015b). Perceptions of sexual violence among men who have sex with men and individuals on the trans-feminine spectrum in Mongolia. Global Public Health, 12(8), 954-969. doi: 10.1080/17441692.2015.1114133

Pelullo, C., Di Giuseppe, G., \& Angelillo, I. (2013). Frequency of Discrimination, Harassment, and Violence in Lesbian, Gay Men, and Bisexual in Italy. Plos ONE, 8(8), e74446. doi: 10.1371/journal.pone.0074446

Pendragon, D. (2010). Coping Behaviors among Sexual Minority Female Youth. Journal Of Lesbian Studies, 14(1), 5-15. doi: $10.1080 / 10894160903058840$

Peter, T., Taylor, C., \& Chamberland, L. (2014). A Queer Day in Canada: Examining Canadian High School Students' Experiences With SchoolBased Homophobia in Two Large-Scale Studies. Journal Of Homosexuality, 62(2), 186-206. doi: 10.1080/00918369.2014.969057

Phillips, G., Hightow-Weidman, L., Fields, S., Giordano, T., Outlaw, A., HalpernFelsher, B., \& Wohl, A. (2013). Experiences of community and parental violence among HIV-positive young racial/ethnic minority men who have sex with men. AIDS Care, 26(7), 827-834. doi: 10.1080/09540121.2013.861571

Piwowarczyk, L., Fernandez, P., \& Sharma, A. (2016). Seeking Asylum: Challenges Faced by the LGB Community. Journal Of Immigrant And Minority Health, 19(3), 723-732. doi: 10.1007/s10903-016-0363-9

Pollock, L., Silva-Santisteban, A., Sevelius, J., \& Salazar, X. (2016). 'You should build yourself up as a whole product': Transgender female identity in Lima, Peru. Global Public Health, 11(7-8), 981-993. doi: 10.1080/17441692.2016.1167932

Porter, J., \& Williams, L. (2011). Intimate Violence Among Underrepresented Groups on a College Campus. Journal Of Interpersonal Violence, 26(16), 3210-3224. doi: 10.1177/0886260510393011

Ports, K., Lee, R., Raiford, J., Spikes, P., Manago, C., \& Wheeler, D. (2017). Adverse Childhood Experiences and Health and Wellness Outcomes among Black Men Who Have Sex with Men. Journal Of Urban Health, 94(3), 375-383. doi: 10.1007/s11524-017-0146-1

Pyra, M., Weber, K., Wilson, T., Cohen, J., Murchison, L., Goparaju, L., \& Cohen, M. (2014). Sexual Minority Status and Violence Among HIV Infected and At-Risk Women. Journal Of General Internal Medicine, 29(8), 1131-1138. doi: 10.1007/s11606-014-2832-y 
Qureshi, R., Zha, P., Kim, S., Hindin, P., Naqvi, Z., \& Holly, C. et al. (2017). Health Care Needs and Care Utilization Among Lesbian, Gay, Bisexual, and Transgender Populations in New Jersey. Journal Of Homosexuality, 65(2), 167-180. doi: 10.1080/00918369.2017.1311555

Reisner, S., Falb, K., Wagenen, A., Grasso, C., \& Bradford, J. (2013). Sexual Orientation Disparities in Substance Misuse: The Role of Childhood Abuse and Intimate Partner Violence Among Patients in Care at an Urban Community Health Center. Substance Use \& Misuse, 48(3), 274-289. doi: 10.3109/10826084.2012.755702

Reuter, T., Newcomb, M., Whitton, S., \& Mustanski, B. (2017). Intimate partner violence victimization in LGBT young adults: Demographic differences and associations with health behaviors. Psychology Of Violence, 7(1), 101-109. doi: $10.1037 /$ vio0000031

Roberts, A., Austin, S., Corliss, H., Vandermorris, A., \& Koenen, K. (2010). Pervasive Trauma Exposure Among US Sexual Orientation Minority Adults and Risk of Posttraumatic Stress Disorder. American Journal Of Public Health, 100(12), 2433-2441. doi: 10.2105/ajph.2009.168971

Roberts, A., Rosario, M., Slopen, N., Calzo, J., \& Austin, S. (2013). Childhood Gender Nonconformity, Bullying Victimization, and Depressive Symptoms Across Adolescence and Early Adulthood: An 11-Year Longitudinal Study. Journal Of The American Academy Of Child \& Adolescent Psychiatry, 52(2), 143-152. doi: 10.1016/j.jaac.2012.11.006

Rodríguez-Madera, S., Padilla, M., Varas-Díaz, N., Neilands, T., Vasques Guzzi, A., Florenciani, E., \& Ramos-Pibernus, A. (2016). Experiences of Violence Among Transgender Women in Puerto Rico: An Underestimated Problem. Journal Of Homosexuality, 64(2), 209-217. doi: 10.1080/00918369.2016.1174026

Rogers, M. (2015). Breaking down barriers: exploring the potential for social care practice with trans survivors of domestic abuse. Health \& Social Care In The Community, 24(1), 68-76. doi: 10.1111/hsc.12193

Rood, B., Puckett, J., Pantalone, D., \& Bradford, J. (2015). Predictors of Suicidal Ideation in a Statewide Sample of Transgender Individuals. LGBT Health, 2(3), 270-275. doi: 10.1089/lgbt.2013.0048

Rosentel, K., Hill, B., Lu, C., \& Barnett, J. (2016). Transgender Veterans and the Veterans Health Administration: Exploring the Experiences of Transgender Veterans in the Veterans Affairs Healthcare System. Transgender Health, 1(1), 108-116. doi: 10.1089/trgh.2016.0006

Russell, S., Everett, B., Rosario, M., \& Birkett, M. (2014). Indicators of Victimization and Sexual Orientation Among Adolescents: Analyses From Youth Risk Behavior Surveys. American Journal Of Public Health, 104(2), 255-261. doi: 10.2105/ajph.2013.301493

Sabidó, M., Kerr, L., Mota, R., Benzaken, A., de A. Pinho, A., \& Guimaraes, M. et al. (2015). Sexual Violence Against Men Who Have Sex with Men in 
Brazil: A Respondent-Driven Sampling Survey. AIDS And Behavior, 19(9), 1630-1641. doi: 10.1007/s10461-015-1016-z

Saldivia Mansilla, C., Faúndez Reyes, B., Sotomayor Llanos, S., \& Cea Leiva, F. (2017). Violencia íntima en parejas jóvenes del mismo sexo en Chile. Ultima Década, 25(46), 184-212. doi: 10.4067/s071822362017000100184

Sandfort, T., Frazer, M., Matebeni, Z., Reddy, V., \& Southey-Swartz, I. (2015). Histories of forced sex and health outcomes among Southern African lesbian and bisexual women: a cross-sectional study. BMC Women's Health, 15(1). doi: 10.1186/s12905-015-0181-6

Sanger, N., \& Lynch, I. (2017). 'You have to bow right here': heteronormative scripts and intimate partner violence in women's same-sex relationships. Culture, Health \& Sexuality, 20(2), 201-217. doi: 10.1080/13691058.2017.1338755

Scheim, A., Santos, G., Arreola, S., Makofane, K., Do, T., \& Hebert, P. et al. (2016). Inequities in access to HIV prevention services for transgender men: results of a global survey of men who have sex with men. Journal Of The International AIDS Society, 19(3 (Suppl 2). doi: 10.7448/ias.19.3.20779

Stone, D., Luo, F., Ouyang, L., Lippy, C., Hertz, M., \& Crosby, A. (2014). Sexual Orientation and Suicide Ideation, Plans, Attempts, and Medically Serious Attempts: Evidence From Local Youth Risk Behavior Surveys, 20012009. American Journal Of Public Health, 104(2), 262-271. doi: 10.2105/ajph.2013.301383

Schramm, Fermin Roland. (2009). Violencia y ética práctica. Salud colectiva, 5(1), 13-25.

Sheridan, L., Scott, A., \& Campbell, A. (2016). Perceptions and Experiences of Intrusive Behavior and Stalking. Journal Of Interpersonal Violence, 088626051665131. doi: 10.1177/0886260516651313

Schilder, A., Anema, A., Pai, J., Rich, A., Miller, C., \& Chan, K. et al. (2014). Association between Childhood Physical Abuse, Unprotected Receptive Anal Intercourse and HIV Infection among Young Men Who Have Sex with Men in Vancouver, Canada. Plos ONE, 9(6), e100501. doi: 10.1371/journal.pone. 0100501

Sekoni, A., Ayoola, O., \& Somefun, E. (2014). Experiences of social oppression among men who have sex with men in a cosmopolitan city in Nigeria. HIVIAIDS - Research And Palliative Care, 21. doi: 10.2147/hiv.s72034

Semple, S., Stockman, J., Goodman-Meza, D., Pitpitan, E., Strathdee, S., \& Chavarin, C. et al. (2016). Correlates of Sexual Violence Among Men Who Have Sex With Men in Tijuana, Mexico. Archives Of Sexual Behavior, 46(4), 1011-1023. doi: 10.1007/s10508-016-0747-x 
Shaw, S., Lorway, R., Deering, K., Avery, L., Mohan, H., \& Bhattacharjee, P. et al. (2012). Factors Associated with Sexual Violence against Men Who Have Sex with Men and Transgendered Individuals in Karnataka, India. Plos ONE, 7(3), e31705. doi: 10.1371/journal.pone.0031705

Shires, D., \& Jaffee, K. (2015). Factors Associated with Health Care Discrimination Experiences among a National Sample of Female-to-Male Transgender Individuals. Health \& Social Work, 40(2), 134-141. doi: 10.1093/hsw/hlv025

Siemieniuk, R., Miller, P., Woodman, K., Ko, K., Krentz, H., \& Gill, M. (2012). Prevalence, clinical associations, and impact of intimate partner violence among HIV-infected gay and bisexual men: a population-based study. HIV Medicine, 14(5), 293-302. doi: 10.1111/hiv.12005

Silva, G., Souza, E., Sena, R., Moura, I., Sobreira, M., \& Miranda, F. (2016). Situações de violência contra travestis e transexuais em um município do nordeste brasileiro. Revista Gaúcha De Enfermagem, 37(2). doi: 10.1590/1983-1447.2016.02.56407

Siqueira, M., Saraiva, L., Carrieri, A., Lima, H., \& Andrade, A. (2009). Homofobia e violência moral no trabalho no Distrito Federal. Organizações \& Sociedade, 16(50), 447-461. doi: 10.1590/s1984-92302009000300003

Smith, H., Markovic, N., Danielson, M., Matthews, A., Youk, A., \& Talbott, E. et al. (2010). Sexual Abuse, Sexual Orientation, and Obesity in Women. Journal Of Women's Health, 19(8), 1525-1532. doi: 10.1089/jwh.2009.1763

Socías, M., Marshall, B., Arístegui, I., Romero, M., Cahn, P., Kerr, T., \& Sued, O. (2014). Factors associated with healthcare avoidance among transgender women in Argentina. International Journal For Equity In Health, 13(1). doi: 10.1186/s12939-014-0081-7

Soliva, T., \& Silva Junior, J. (2014). Entre revelar e esconder: pais e filhos em face da descoberta da homossexualidade. Sexualidad, Salud Y Sociedad (Rio De Janeiro), (17), 124-148. doi: 10.1590/1984-6487.sess.2014.17.08.a

Souza, M., Malvasi, P., Signorelli, M., \& Pereira, P. (2015). Violência e sofrimento social no itinerário de travestis de Santa Maria, Rio Grande do Sul, Brasil. Cadernos De Saúde Pública, 31(4), 767-776. doi: 10.1590/0102-311x00077514

Souza, M., Silva, M., \& Carvalho, R. (2010). Revisão integrativa: o que é e como fazer. Einstein, 8(1), 102-106

Steele, S., Everett, B., \& Hughes, T. (2017). Influence of Perceived Femininity, Masculinity, Race/Ethnicity, and Socioeconomic Status on Intimate Partner Violence Among Sexual-Minority Women. Journal Of Interpersonal Violence, 088626051668317. doi: 10.1177/0886260516683176 
Stephenson, R., Voux, A., \& Sullivan, P. (2011). Intimate Partner Violence and Sexual Risk-taking among Men Who Have Sex with Men in South Africa. West J Emerg Med., 12(3).

Stephenson, R., Hast, M., Finneran, C., \& Sineath, C. (2014). Intimate partner, familial and community violence among men who have sex with men in Namibia. Culture, Health \& Sexuality, 16(5), 473-487. doi: 10.1080/13691058.2014.889753

Stephenson, R., \& Finneran, C. (2016). Minority Stress and Intimate Partner Violence Among Gay and Bisexual Men in Atlanta. American Journal Of Men's Health, 11(4), 952-961. doi: 10.1177/1557988316677506

Stephenson, R., Khosropour, C., \& Sullivan, P. (2010). Reporting of Intimate Partner Violence among Men Who Have Sex with Men in an Online Survey. West J Emerg Med, 11(3).

Stoffelen, J., Kok, G., Hospers, H., \& Curfs, L. (2012). Homosexuality among people with a mild intellectual disability: an explorative study on the lived experiences of homosexual people in the Netherlands with a mild intellectual disability. Journal Of Intellectual Disability Research, 57(3), 257267. doi: 10.1111/j.1365-2788.2011.01532.x

Stults, C., Javdani, S., Greenbaum, C., Kapadia, F., \& Halkitis, P. (2016). Intimate Partner Violence and Sex Among Young Men Who Have Sex With Men. Journal Of Adolescent Health, 58(2), 215-222. doi: 10.1016/j.jadohealth.2015.10.008

Sweet, T., \& L. Welles, S. (2012). Associations of Sexual Identity or Same-Sex Behaviors With History of Childhood Sexual Abuse and HIVISTI Risk in the United States. JAIDS Journal Of Acquired Immune Deficiency Syndromes, 59(4), 400-408. doi: 10.1097/qai.0b013e3182400e75

Szalacha, L., Hughes, T., McNair, R., \& Loxton, D. (2017). Mental health, sexual identity, and interpersonal violence: Findings from the Australian longitudinal Women's health study. BMC Women's Health, 17(1). doi: 10.1186/s12905-017-0452-5

Tait, R. (2015). Alcohol-related victimisation: Differences between sexual minorities and heterosexuals in an Australian national sample. Drug And Alcohol Review, 34(4), 366-374. doi: 10.1111/dar.12265

Taliaferro, L., \& Muehlenkamp, J. (2017). Nonsuicidal Self-Injury and Suicidality Among Sexual Minority Youth: Risk Factors and Protective Connectedness Factors. Academic Pediatrics, 17(7), 715-722. doi: 10.1016/j.acap.2016.11.002

Teixeira-Filho, F., \& Rondini, C. (2012). Ideações e tentativas de suicídio em adolescentes com práticas sexuais hetero e homoeróticas. Saúde $\mathrm{E}$ Sociedade, 21(3), 651-667. doi: 10.1590/s0104-12902012000300011

Tomori, C., McFall, A., Srikrishnan, A., Mehta, S., Nimmagadda, N., \& Anand, S. et al. (2016). The prevalence and impact of childhood sexual abuse on 
HIV-risk behaviors among men who have sex with men (MSM) in India. BMC Public Health, 16(1). doi: 10.1186/s12889-016-3446-6

Toomey, R., McGuire, J., \& Russell, S. (2012). Heteronormativity, school climates, and perceived safety for gender nonconforming peers. Journal Of Adolescence, 35(1), 187-196. doi: 10.1016/j.adolescence.2011.03.001

Valentine, S., Peitzmeier, S., King, D., O'Cleirigh, C., Marquez, S., Presley, C., \& Potter, J. (2017). Disparities in Exposure to Intimate Partner Violence Among Transgender/Gender Nonconforming and Sexual Minority Primary Care Patients. LGBT Health, 4(4), 260-267. doi: 10.1089/lgbt.2016.0113

Vertommen, T., Schipper-van Veldhoven, N., Wouters, K., Kampen, J., Brackenridge, C., \& Rhind, D. et al. (2016). Interpersonal violence against children in sport in the Netherlands and Belgium. Child Abuse \& Neglect, 51, 223-236. doi: 10.1016/j.chiabu.2015.10.006

Whitton, S., Newcomb, M., Messinger, A., Byck, G., \& Mustanski, B. (2016). A Longitudinal Study of IPV Victimization Among Sexual Minority Youth. Journal Of Interpersonal Violence, 088626051664609. doi: $10.1177 / 0886260516646093$

Wijngaarden, J., Schunter, B., \& Iqbal, Q. (2013). Sexual abuse, social stigma and HIV vulnerability among young feminised men in Lahore and Karachi, Pakistan. Culture, Health \& Sexuality, 15(1), 73-84. doi: 10.1080/13691058.2012.743186

Wilsnack, S., Kristjanson, A., Hughes, T., \& Benson, P. (2012). Characteristics of childhood sexual abuse in lesbians and heterosexual women. Child Abuse \& Neglect, 36(3), 260-265. doi: 10.1016/j.chiabu.2011.10.008

Woodyatt, C., \& Stephenson, R. (2016). Emotional intimate partner violence experienced by men in same-sex relationships. Culture, Health \& Sexuality, 18(10), 1137-1149. doi: 10.1080/13691058.2016.1175027

Yu, Y., Xiao, S., \& Liu, K. (2013). Dating Violence Among Gay Men in China. Journal Of Interpersonal Violence, 28(12), 2491-2504. doi: 10.1177/0886260513479028

Zea, M., Reisen, C., Bianchi, F., Gonzales, F., Betancourt, F., Aguilar, M., \& Poppen, P. (2013). Armed conflict, homonegativity and forced internal displacement: implications for HIV among Colombian gay, bisexual and transgender individuals. Culture, Health \& Sexuality, 15(7), 788-803. doi: 10.1080/13691058.2013.779028

Zhang, Y., Best, J., Tang, W., Tso, L., Liu, F., \& Huang, S. et al. (2016). Transgender sexual health in China: a cross-sectional online survey in China. Sexually Transmitted Infections, 92(7), 515-519. doi: 10.1136/sextrans-2015-052350

Zhao, Y., Montoro, R., Igartua, K., \& Thombs, B. (2010). Suicidal Ideation and Attempt Among Adolescents Reporting "Unsure" Sexual Identity or Heterosexual Identity Plus Same-Sex Attraction or Behavior: Forgotten 
Groups?. Journal Of The American Academy Of Child \& Adolescent Psychiatry, 49(2), 104-113. doi: 10.1016/j.jaac.2009.11.003

Zou, C., \& Andersen, J. (2015). Comparing the Rates of Early Childhood Victimization across Sexual Orientations: Heterosexual, Lesbian, Gay, Bisexual, and Mostly Heterosexual. PLOS ONE, 10(10), e0139198. doi: 10.1371/journal.pone.0139198 